ANDRÉ SCHMIDT SUAIDEN

AVALIAÇÃO DO PAPEL DA OBESIDADE EM MODELO MURINO DE ASMA NEUTROFÍLICA EXPERIMENTAL

Dissertação apresentada ao Programa de Pós Graduação em Farmacologia do Instituto de Ciências Biomédicas da Universidade de São Paulo, para obtenção do Título de Mestre em Ciências. 


\section{AVALIAÇÃO DO PAPEL DA OBESIDADE EM MODELO MURINO DE ASMA NEUTROFÍLICA EXPERIMENTAL}

Dissertação apresentada ao Programa de PósGraduação em Farmacologia do Instituto de Ciências Biomédicas da Universidade de São Paulo, para obtenção do Título de Mestre em Ciências.

Área de Concentração: Farmacologia

Orientador: Prof. Dr. Wothan Tavares de Lima

Versão Corrigida. A versão original eletrônica, encontrase disponível tanto na Biblioteca do ICB quanto na Biblioteca Digital de Teses e Dissertações da USP (BDTD) 
CATALOGAÇÃO NA PUBLICAÇÃO (CIP)

Serviço de Biblioteca e informação Biomédica

do Instituto de Ciências Biomédicas da Universidade de São Paulo

Ficha Catalográfica elaborada pelo(a) autor(a)

Schmidt Suaiden, André

Avaliação do papel da obesidade em modelo murino de asma neutrofilica experimental / André Schmidt

Suaiden; orientador Wothan Tavares de Lima. -- Säo Paulo, 2017 .

$112 \mathrm{p}$.

Dissertação (Mestrado) ) -- Universidade de São Paulo, Instituto de Ciências Biomédicas.

1. Obesidade. 2. Asma. 3. Asma neutrofilica. 4. Mulheres. 5. camundongos. I. Tavares de Lima, Wothan, orientador. II. Título. 
Candidato(a): André Schmidt Suaiden.

Título da Dissertação: Avaliação do papel da obesidade em modelo murino de asma neutrofílica.

Orientador(a): Prof. Dr. Wothan Tavares de Lima

A Comissão Julgadora dos trabalhos de Defesa da Dissertação de Mestrado, em sessão pública realizada a considerou
( ) Aprovado(a)
( ) Reprovado(a)

Examinador(a): Assinatura:

Nome:

Instituição:

Examinador(a): Assinatura:

Nome:

Instituição:

Presidente: Assinatura:

Nome:

Instituição: 


\section{Certificado}

Certificamos que o protocolo registrado sob $n^{\circ} 15$ nas fls. 16 do livro 03 para uso de animais em experimentaças, sob a responsabilidade do Prof(a) Drfa)) Wothan Tavares de Lima, Coordenador (a) da Linha de pesquisa "Obesidade e hormônios sexuais fermininos como moduladores da inflamação alérgica puimonar" do qual participam D's\} aluno(s) Evelyn Thais Fantozzi, Pesquisadores Ricardo Martins Oliveira Filho, Boris Vargaftig, Caroline Marcantonio Ferreira, Estagiários Guilherme Henrique Gatti da Silva, Barbara Lais Santiago Rocha, Andre Schmidt Suaiden, está de acordo com as Principios Eticos de Experimentação Animal adotado pela Sociedade Brasileira de Ciência de Animais de Laboratório (SBCAL) e foi aprowado pela COMISSẮO DE ETICA NO USO DE ANIMAIS ICEUA) em 25.03.2014, com validade de 4 anos.

Sảo Paulo, 27 de março de 2014.
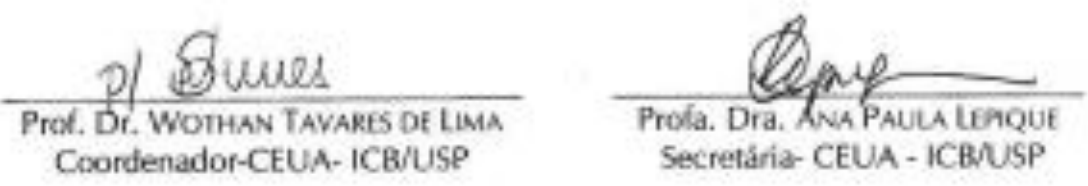


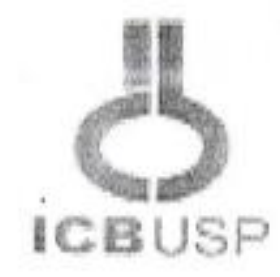

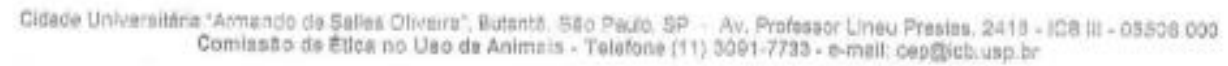

Decl. CEUA.072/2015

DECLARAC Ã O

Em adendo ao Certificado 015/2014/CEUA, datado de 25/03/2014, e por solicitação do Prof. Dr. Wothan Tavares de Lima, responsável pela linha de Pesquisa, autorizo a inclusão do aluno André Schmidt Suaiden ao Projeto de Pesquisa "Obesidade e hormônios sexuais femininos como moduladores da inflamação alérgica pulmonar", uma vez que se trata de utilizaçẫo da mesma espécie animal e de métodos experimentais similares ao Projeto.

São Paulo, 31 de agosto de 2015.

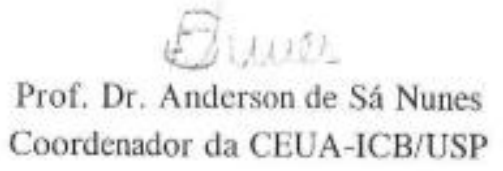


A minha família pelo entendimento da minha ausência, pelo apoio e pela dedicação durante toda minha jornada. Aos meus amigos, pelas alegrias, tristezas e dores compartilhadas. Com vocês, as pausas entre um parágrafo e outro de produção melhora tudo o que tenho produzido na vida. 


\section{AGRADECIMENTOS}

Desafio tão grande quanto escrever esta dissertação, foi utilizar apenas duas páginas para agradecer as pessoas que de alguma forma me ajudaram em minha trajetória cientifica e que contribuíram para minha formação acadêmica.

Acredito que qualquer trabalho cientifico e discussão acadêmica, só aconteça quando se trabalha em equipe, e este não foi tão diferente.

Primeiramente devo agradecer aos meu pais Denise e Ronaldo pela formação que me deram, sem vocês não teria chegado a este momento.

Agradeço ao meu orientador Prof. Wothan Tavares de Lima, pela orientação, pela amizade, e principalmente pelos ensinamentos. Estes anos com você me transformaram em uma pessoa mais ética e dedicada, obrigado por contribuir para com minha formação. Agradeço por ter sido você a primeira pessoa a me mostrar o caminho da ciência e da inflamação você é uma inspiração para continuar neste caminho.

Agradeço as minhas colegas de laboratórios Helô, Evelyn e Sara pelas risadas e companheirismo.

À Cida, Henrique e Renato por estarem dispostos nos dias longos de experimentos com mecânica pulmonar e por contribuir significativamente para que este trabalho saísse. Além das muitas e divertidas risadas nos momentos de flexi-Vent.

À Carol, que tanto contribui para esta dissertação. Agradeço sua ajuda e orientação e obrigado por me ensinar a entender e me apaixonar por asma.

Estendo meus agradecimentos à Carmen e Jennifer pelos momentos de café e desabafos na copinha do departamento de farmacologia.

À Mônica e à Camila, pela simpatia e dedicação em sempre nos atender.

À Sandra pela grandiosa ajuda e cuidados com nossos animais.

Ao meu grande amigo Tiago, companheiro e idealizador das nossas aventuras e trajetória em terras paulistanas e por me suportar nas horas de estresse e mesmo assim não deixar de lado nossa amizade.

Ao meu amigo, irmão, filho e horas pai Hakam, por acreditar nesta trajetória e nunca me deixar desistir e mesmo nos períodos de estresse estar sempre ao meu lado.

A Yan, que me ensinou tudo sobre imunologia, e que tanto contribui para que nossos dados saíssem perfeitos dedico esta dissertação. Agradeço sua ajuda e orientação. Obrigado por me ensinar a entender imunologia.

À CAPES e à FAPESP pelo apoio financeiro. 
A sensação que fica é que estamos apenas começando, e que ainda daremos muitas risadas e teremos muitas histórias para contarmos ainda, claro acompanhado de um bom café. Que venham as novas experiências! 
O sucesso nasce do querer, da determinação e persistência em se chegar a um objetivo. Mesmo não atingindo o alvo, quem busca e vence obstáculos, no mínimo fará coisas admiráveis." (José de Alencar) 


\section{RESUMO}

SUAIDEN, A. S. Avaliação do papel da obesidade em modelo murino da asma neutrofílica experimental. 2017.112f. Dissertação (Mestrado Farmacologia) - Instituto de Ciências Biomédicas, Universidade de São Paulo, São Paulo, 2016.

A associação da obesidade com a asma atópica está bem descrita. Embora reconhecidamente uma patologia mediada por eosinófilos, a asma apresenta fenótipos distintos, onde os neutrófilos exercem relevante papel na inflamação pulmonar e manutenção da inflamação.

Existem dados médicos de que mulheres obesas asmáticas são mais propensas a desenvolver a asma mediada por neutrófilos, cuja característica é ser de difícil controle, notadamente por ser refratária à corticoterapia. Todavia, ainda não existem modelos experimentais de asma neutrofílica, que visem a ligar os mecanismos associados à resistência aos corticoides em mulheres com asma neutrofílica.

No presente estudo, caracterizamos parcialmente um modelo experimental de asma neutrofílica em camundongos fêmeas e apresentamos dados do papel da obesidade no fenótipo inflamatório pulmonar.

Para tanto, grupos de camundongos fêmeas Balb/c foram mantidas com dieta hiperlipídica (DH) ou convencional. (DC). Os animais foram sensibilizados com ovoalbumina e adjuvante completo de Freund. O desafio por via intranasal foi conduzido no $21^{\circ}, 22^{\circ}$ e $23^{\circ}$ dia após a sensibilização. Decorrido das 24 horas do último desafio, os animais foram submetidos a eutanásia e os experimentos realizados.

Os nossos dados indicam que a dieta hiperlipídica determinou aumento significativo de concentrações séricas de glicose, HDL, triglicerídeos e colesterol. Paralelamente, a DH também elevou os índices morformétricos dos animais comparativamente aos animais mantidos com a DC.

Quando animais obesos e não obesos foram submetidos à indução da inflamação neutrofílica, nós observamos que o período de indução da asma resultou em significativo aumento dos números totais de células no lavado broncoalveolar de animais mantidos com dieta hiperlipídica ou dieta convencional. A análise do perfil de células recuperadas no lavado broncoalveolar revelou que ambos os grupos (DH e DC) tiveram aumento significativo de neutrófilos, eosinófilos e redução de mononucleares. Todavia a quantidade de células de neutrófilos nos grupos (DH e DC) se sobrepõe aos de eosinófilos, mas sem haver diferenças entre os grupos. A atividade da enzima mieloperoxidase (MPO) e da enzima eosinoperoxidase (EPO) no pulmão dos animais do grupo $\mathrm{DH}$ foi maior do que o grupo DC. Para investigarmos o perfil inflamatório envolvido na asma de difícil controle analisamos os mediadores inflamatórios como citocinas e imunoglobulinas envolvidas no perfil de asma neutrofílica presentes no lavado broncoalveolar. Observamos aumento dos mediadores IL-1 $\beta$, IL-2, IL-5, IL-6, IL-10, IL-13 dos animais sensibilizados e desafiados com OVA, observamos também aumento das citocinas TNFa, INFy e IL-17 característica do perfil citocinas Th1 e diminuição da citocina IL-4 dos animais sensibilizados e desafiados com OVA que receberam $\mathrm{DH}$. Ainda observamos um maior aumento da imunoglobulina tipo IgG nos animais sensibilizados e desafiados em comparação aos animais controle e um maior aumento comparado com imunoglobulina do tipo IgE. Nossos resultados mostraram também que animais com perfil inflamatório neutrofílico possuem certa resistência ao anti-inflamatório budesonida comparado aos animais com perfil inflamatório eosinofílico.

Neste contexto ainda investigamos a resistência e elastância pulmonar avaliadas no flexiVent, um ventilador mecânico para animais de pequeno porte, além da análise histológica para avaliar a arquitetura pulmonar. 
Nossos dados permitem sugerir que o modelo de asma neutrofílica está, sob ponto de vista inflamatório caracterizado, e que o recrutamento de neutrófilos independe da obesidade. Por fim estes dados podem contribuir para a compreensão dos mecanismos que regulam a asma de difícil controle em mulheres obesas.

Palavras-chave: Obesidade. Asma neutrofílica. Reatividade das vias aéreas. Mecânica pulmonar. 
SUAIDEN, A. S. Evaluation of the role of obesity in the murine model of experimental neutrophilic asthma .2017.112p. Maters thesis (Pharmacology) - Institute os Biomedical Sciences University of São Paulo, São Paulo, 2016.

The association of obesity with atopic asthma is well described. Although admittedly an eosinophil-mediated pathology, asthma presents distinct phenotypes where neutrophils exert a relevant role in lung inflammation and maintenance of inflammation.

There are medical data that obese asthmatic women are more likely to develop neutrophil-mediated asthma, whose characteristic is to be difficult to control, notably because it is refractory to corticosteroids. However, there are not no experimental models of neutrophilic asthma yet, to link mechanisms associated with resistance to corticosteroids in women with neutrophilic asthma.

In the present study, we partially characterized an experimental model of neutrophilic asthma in female mice and presented data on the role of obesity in the pulmonary inflammatory phenotype.

For this purpose, groups of female Balb / c mice were maintained on a hyperlipidic (HD) or conventional diet (C.D). The animals were sensitized with ovalbumin and Freund's complete adjuvant. The intranasal challenge was conducted on the 21st, 22nd and 23rd day after sensitization. After 24 hours of the last challenge, the animals were submitted to euthanasia and the experiments were performed.

Our data indicate that the hyperlipid diet resulted in a significant increase in serum glucose, HDL, triglyceride and cholesterol concentrations. At the same time HD also increased the morphometric values of the animals compared to the animals kept with the CD.

When obese and non-obese animals were subjected to induction of neutrophilic inflammation, we observed that the induction period of asthma resulted in a significant increase the total number of cells in the bronchoalveolar lavage of animals kept on a hyperlipid diet or conventional diet. The analysis of the cell profile recovered in the bronchoalveolar lavage revealed that both groups (HD and CD) had a significant increase in neutrophils, eosinophils and mononuclear reduction. However, the amount of neutrophil cells in the groups (HD and CD) overlap those the in eosinophils, but there were no differences between the groups. The activity of the enzyme myeloperoxidase (MPO) and the enzyme eosinoperoxidase (EPO) in the lung of the animals of the HD group was higher than the CD group. To evaluate the inflammatory profile involved in difficult-tocontrol asthma, we analyzed the inflammatory mediators as cytokines and the immunoglobulins involved in the neutrophilic asthma profile present in the bronchoalveolar lavage. We observed an increase in the mediators IL-1 $\beta$, IL-2, IL-5, IL-6, IL-10, IL-13 from animals sensitized and challenged with OVA, we also observed increase in the cytokines TNFa, INFy and IL-17 characteristic of the Th1 cytokine profile, and decrease in the cytokine IL-4 of animals sensitized and challenged with OVA that receives HD. We also observed a greater increase of the IgG type immunoglobulin in the sensitized and challenged animals compared to the control animals and a greater increase compared to IgE type immunoglobulin. Our results also showed that animals with a neutrophilic inflammatory profile have a certain resistance to anti-inflammatory budesonide compared to animals with inflammatory eosinophilic profile.

In this context, we investigated the resistance and pulmonary elastance evaluated in flexiVent, a mechanical ventilator for airway animals, as well as histological analysis to evaluate pulmonary architecture. 
Our data allow us to suggest that the neutrophilic asthma model is well a characterized inflammatory point of view, and that neutrophil recruitment is independent of obesity. Finally, these data may contribute to the understanding of the mechanisms that regulate difficult-to-control asthma in obese women.

Keywords: Obesity. Neutrophilic asthma. Reactivity of the airways. Pulmonary mechanics. 


\section{LISTA DE FIGURAS}

Figura 1- Indução da inflamação pulmonar neutrofílica ........................................38

Figura 2 - Indução da inflamação pulmonar eosinofílica .........................................39

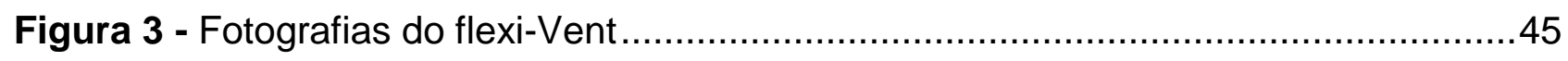

Figura 4 - Evolução ponderal e consumo de ração ao longo de 10 semanas.................48

Figura 5 - Efeito da dieta com ração hiperlípidica sobre a massa corporal $(A)$, depósito de tecido adiposo retroperitoneal $(\mathrm{B})$ e tecido adiposo gonadal $(\mathrm{C})$................................49

Figura 6 - Efeito da dieta hiperlipídica sobre a concentração sérica de glicose (A), HDL

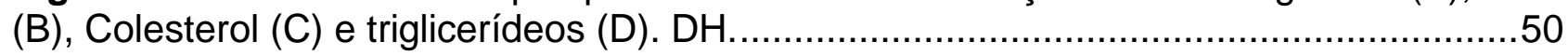

Figura 7 - Efeito do tipo de dieta sobre o número de células totais recuperados no lavado broncoalveolar.

Figura 8 - Efeito do tipo de dieta sobre a quantidade de eosinófilos recuperados no lavado broncoalveolar.

Figura 9 - Efeito do tipo de dieta sobre a quantidade de neutrófilos .53

Figura 10 - Efeito do tipo de dieta sobre a quantidade de mononucleares recuperados no lavado broncoalveolar.

Figura 11 - Efeito do tipo de dieta sobre a atividade das enzimas eosinoperoxidase (EPO) e mieloperoxidase (MPO) em pulmão

Figura 12 - Concentração das imunoglobulinas G e E, em pulmão

Figura 13 - Diferença entre o número de eosinófilos e neutrófilos recuperados no lavado broncoalveolar.... .59

Figura 14 - Avaliação da mecânica pulmonar de animais com asma neutrofílica e eosinofílica tratados.

Figura 15 - Efeito tratamento com budesonida (BUD) sobre o número de células recuperados no lavado broncoalveolar

Figura 16 - Efeito tratamento com budesonida (BUD) sobre o número de células diferenciais recuperados no lavado broncoalveolar.

Figura 17 - Avaliação da mecânica pulmonar de animais sensibilizados e desadfiados com OVA e do grupo controle mantidos sob dieta convencional e hiperlipídica.

Figura 18 - Efeito do tipo de dieta sobre a concentração de TNFa recuperados no lavado broncoalveolar

Figura 19 - Efeito do tipo de dieta sobre a concentração de IL1- $\beta$ recuperados no lavado broncoalveolar. 
Figura 20 - Efeito do tipo de dieta a concentração de INFy recuperados no lavado broncoalveolar

Figura 21 - Efeito do tipo de dieta sobre a concentração de IL-2 recuperados no lavado broncoalveolar

Figura 22 - Efeito do tipo de dieta sobre a concentração de IL-10 recuperados no lavado broncoalveolar

Figura 23 - Efeito do tipo de dieta sobre a concentração de IL-6 recuperados no lavado broncoalveolar .74

Figura 24 - Efeito do tipo de dieta a concentração de IL-4 recuperados no lavado broncoalveolar .75

Figura 25 - Efeito do tipo de dieta sobre a concentração de IL-5 recuperados no lavado broncoalveolar .76

Figura 26 - Efeito do tipo de dieta sobre a concentração de IL-13 recuperados no lavado broncoalveolar .77

Figura 27 - Efeito do tipo de dieta sobre a concentração de IL-17 recuperados no lavado broncoalveolar .78

Figura 28 - Efeito do tipo de dieta sobre a porcentagem da deposição de colágeno de animais controle e animais sensibilizados e desafiados com OVA

Figura 29 - Fotomicrografias de cortes histológicos de pulmão corados com Pícro sírius para avaliação da deposição de colágeno

Figura 30 - Efeito do tipo da dieta sobre a espessura das vias aéreas (painel A) e da porcentagem de músculo das vias aéreas (painel B) .83

Figura 31 - Fotomicrografias de cortes histológicos de pulmão corados com hematoxilina e eosina para avaliação de espessura das vias aéreas e porcentagem da área do músculo das vias aéreas. 


\section{LISTA DE TABELAS}

Tabela 1 - Tabela nutricional com quantidade de calorias, proteínas e lipídios para

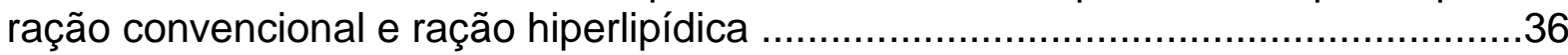




\section{LISTA DE ABREVIATURAS E SIGLAS}

BUD - Budesonida

DC- Dieta Convencional

DH - Dieta Hiperlipídica

EPO - Enzima eosinoperoxidase

FEV1 - Fluxo expiratório forçado em 1 segundo

G - Caracteriza a disposição de energia no tecido pulmonar

H - Caracteriza energia acumulada no tecido pulmonar

HDL - High Density Lipoprotein

I.n. - via intranasal

I.p. - via intraperitoneal

IFN - Interferon

IgE - Imunoglobulina E

IgG - Imunoglobulina $G$

IL-1 $\alpha$ - Interleucina $1 \alpha$

IL-10 - Interleucina 10

IL-13 - Interleucina 13

IL-17 - Interleucina 17

IL-1 $\beta$ - Interleucina $1 \beta$

IL-2 - Interleucina 2

IL-5 - Interleucina 5

IL-6 - Interleucina 6

IMC - Índice de Massa Corpórea

LBA - Lavado broncoalveolar

M1- Macrófagos do tipo 1

M2 - Macrófagos do tipo 2

MCh - Metacolina

MPO - Enzima Mieloperoxidase

OVA - Ovoalbumina

OVx - Remoção dos ovários (ooforectómia)

PBS - Phosphate Buffered Saline

RBP4 - proteína ligadora de retinol do tipo 4

$\mathbf{R n}$ - Resistência das vias aéreas 
S.c. - via subcutânea

TNF- $\alpha$ - Fator de necrose tumoral $\alpha$ 


\section{SUMÁRIO}

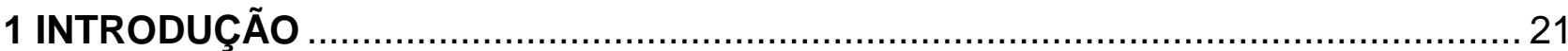

1.1 Obesidade e imunometabolismo .................................................................... 21

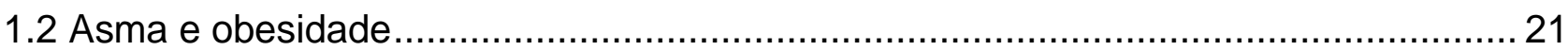

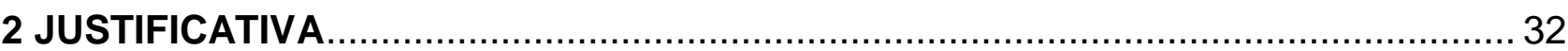

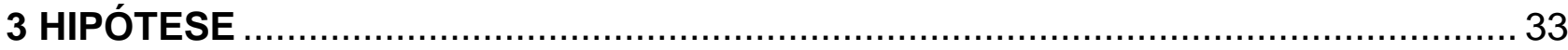

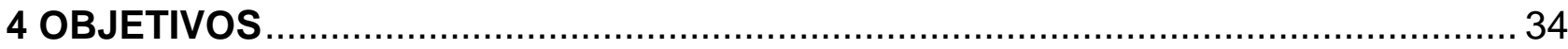

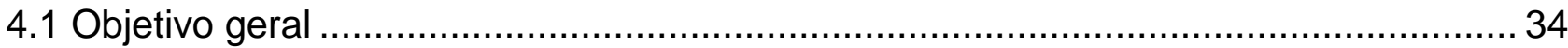

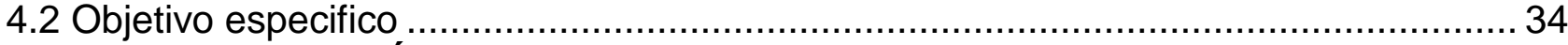

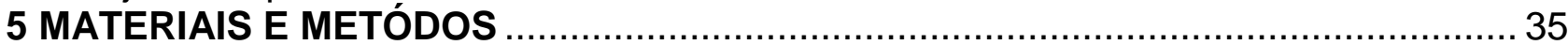

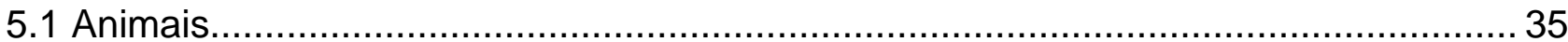

5.1.2 Regime alimentar com dieta hiperlipídica e determinação do ganho de massa....... 36

5.1.3 Avaliação da quantidade de tecido adiposos retro peritoneal e tecido adiposo

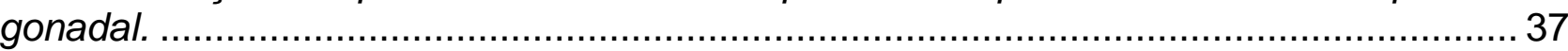

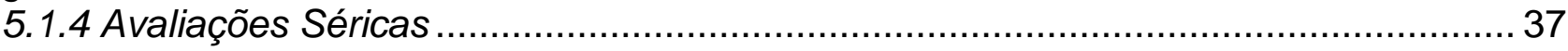

5.2 Modelo de inflamação pulmonar ................................................................ 38

5.2.1 Indução da inflamação pulmonar neutrofilica .................................................... 38

5.2.2 Indução da inflamação pulmonar eosinofílica..................................................... 39

5.2.3 Tratamento Farmacológico....................................................................... 40

5.3. Determinação do número de células recrutadas para o pulmão ............................. 40

5.3.1 Lavado broncoalveolar (LBA) ........................................................................ 40

5.3.2 Avaliação da atividade pulmonar de mieloperoxidase (MPO) e

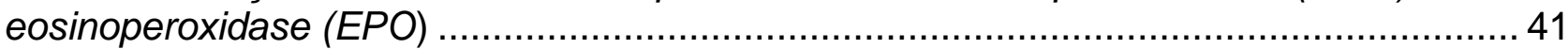

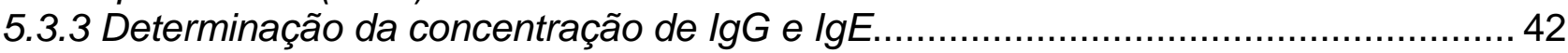

5.3.4 Quantificação de mediadores inflamatórios..................................................... 42

5.4 Análise histológica e morformetria do pulmão .................................................... 43

5.4.1 Coloração de Picro-Sírius e Resorcina-Fucsina Oxidada...................................... 43

5.4.2 Coloração de Hematoxilina e Eosina ............................................................... 43

5.5 Avaliação da mecânica pulmonar..................................................................... 44

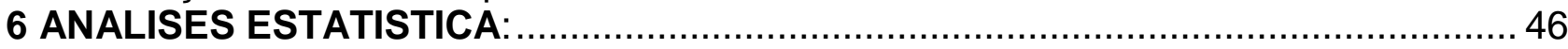

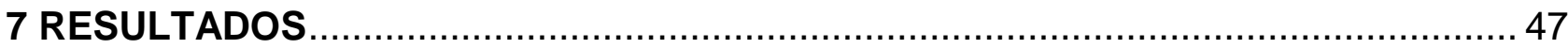

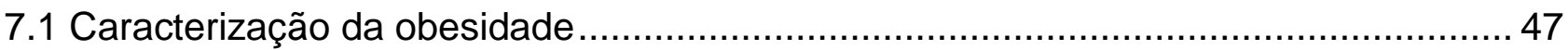

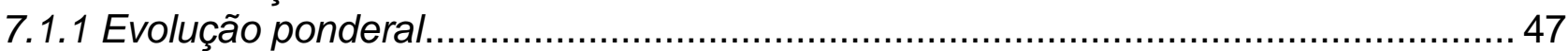

7.1.2 Ganho de Massa, Tecido Adiposo Retroperitoneal e Gonadal............................... 49

7.1.3 Concentração sérica de glicose, colesterol, HDL e triglicerídeos ............................ 51

7.2 Caracterização da asma neutrofilica experimental ............................................ 52

7.2.1 Células totais do lavado bronco alveolar (LBA) ............................................ 52

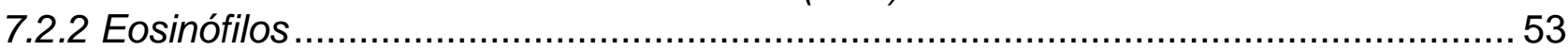

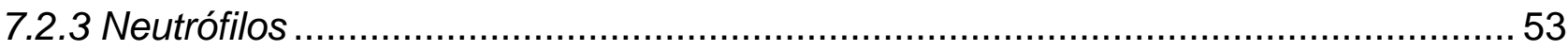

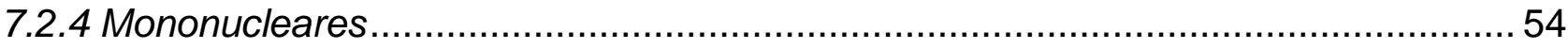

7.2.5 Atividade das enzimas eosinoperoxidase (EPO) e mieloperoxidase (MPO) no pulmão ................................................................................................................ 55

7.2.6 Concentração das imunoglobulinas ( $\lg G)$ e (lgE) no lavado broncoalveolar e no

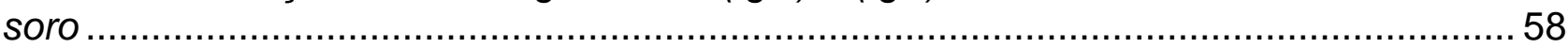

7.2.7 Perfil de células recuperadas no lavado broncoalveolar de animais com inflamação neutrofílica e eosinofílica..................................................................... 60 7.2.8 Avaliação da mecânica pulmonar de animais com asma neutrofílica ou eosinofílica tratados com budesonida. 
7.2.9 Efeito do tratamento dos animais com budesonida sobre o número de células recuperadas do lavado broncoalveolar

7.2.10 Efeito do tratamento dos animais com budesonida sobre o número de células diferenciais recuperadas do lavado broncoalvelar

7.3 Asma e Obesidade.

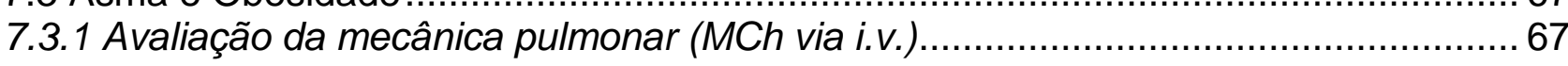

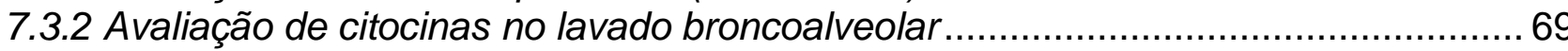

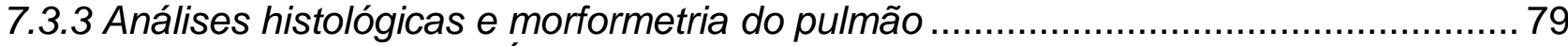

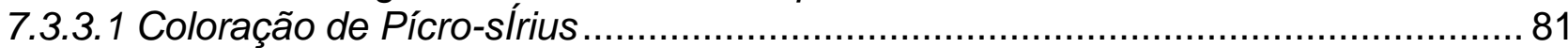

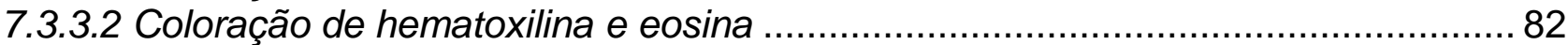

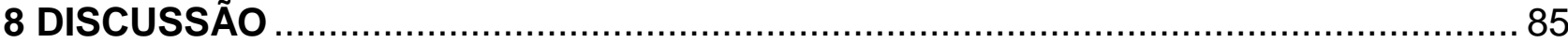

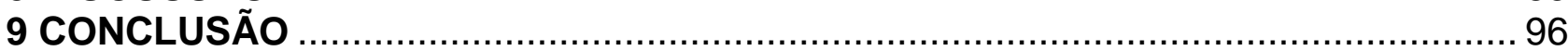

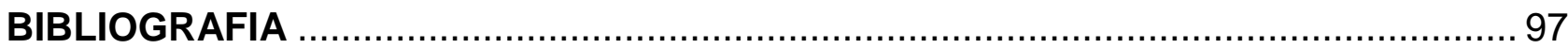




\section{INTRODUÇÃO}

\subsection{Obesidade}

Obesidade e sobrepeso são definidos como o acúmulo anormal ou excessivo de gordura que pode fragilizar a saúde. A Organização Mundial da Saúde (OMS) estabelece que a relação peso/altura de um indivíduo adulto representa índice aproximado de classificação de sobrepeso ou obesidade. Define-se assim, o índice de massa corporal (IMC) como a relação entre peso e massa corporal como segue: $I M C=P e s o$ / [altura ${ }^{2}$ ], onde IMC $\geq 25$ representa condição de sobrepeso e IMC $\geq 30$ indica obesidade. Embora útil, o IMC deve ser analisado com cautela, visto que o teor de gordura no organismo pode variar entre indivíduos. Portanto, a leitura do IMC como diagnóstico de sobrepeso ou obesidade deve considerar fatores como: estilo de vida, naturalidade do indivíduo, compleição física, etc. (VIGITEL, 2012).

Desde a década de 1980, as taxas de obesidade no mundo mais que dobraram, estudos realizados em 2008 revelaram que mais de 1.4 bilhões de adultos são obesos, e em 2014 mais de 1,9 bilhões de pessoas, sendo que 500 milhões de casos foram registrados em mulheres. Em 2014, mais de 41 milhões de crianças foram diagnosticadas com sobrepeso. A maioria da população mundial vive em países, onde o excesso de peso e obesidade matam mais pessoas do que 0 baixo peso. (http://www.who.int/mediacentre/factsheets/fs311/en/).

Estudos conduzidos pelo Ministério da Saúde e realizados pela Vigilância de Fatores de Risco e Proteção para Doenças Crônicas por Inquérito Telefônico (VIGITEL) revelaram aumento na taxa de obesidade no Brasil. Nesse estudo (VIGITEL 2015) revelou-se que $60 \%$ da população brasileira estão com excesso de peso (em 2006 esse índice era 43\% e em 2008 era de 49\%). Neste estudo fica evidenciado que cerca de 82 milhões de pessoas apresentam Índice de Massa Corpórea igual ou maior a 25 o que representa sobrepeso ou obesidade. Estes dados coloca o Brasil como o quinto país mais obeso do mundo. Ainda, observa-se uma tendência para elevação mais acentuada para mulheres (Homens: $2015=55 \%$; Mulheres: $2015=58,2 \%$ ). Estes dados foram obtidos da Pesquisa Nacional de Saúde (PNS) realizado pelo Instituto Brasileiro de Geografia e Estatística (IBGE) no segundo semestre de 2013. (http://www.brasil.gov.br/saude/2015/08/mais-dametade-dos-adultos-estao-acima-do-peso) acesso em 26/09/2016. Dados mais 
atuais indicaram que a obesidade é um dos maiores problemas de saúde pública do mundo, e segundo a Organização Mundial de Saúde (OMS), a projeção é de que em 2025, cerca de 2,3 bilhões de adultos estejam com sobrepeso e mais de 700 milhões estejam obesos. Pela primeira vez em oito anos consecutivos o porcentual de excesso de peso e obesidade se manteve estável em nosso país segundo o Ministério da

Saúde. (http://www.abeso.org.br/lenoticia/1115/vigitel+2013+aponta+para+estabilizacao+da +obesidade+no+pa\%C3\%ADs.shtml) acesso em 26/09/2014.

A obesidade tem origem no desbalanceamento energético, onde a quantidade de energia consumida se sobrepõe à despendida. Como consequência a obesidade se associa ao desenvolvimento de resistência à insulina, hipertensão arterial, dislipidemia, doença cardiovascular, diabetes, distúrbio músculo esquelético, além de alguns tipos de cânceres (ABALLAY et al., 2013; ALAM et al., 2012).

Evidências mostram que, a obesidade induz a um estado de inflamação crônica de baixo grau. Admite-se que neste quadro de inflamação crônica de baixa intensidade, adipócitos e células do sistema imune liberam quantidades apreciáveis de mediadores da inflamação como: fator de necrose tumoral alfa (TNF- $\alpha$ ) e interleucina (IL) IL-6 (AZEVEDO; MONTEIRO, 2010). Vale notar que o tecido adiposo foi considerado por muito tempo uma estrutura associada ao estoque de energia. Atualmente esta conotação já não se sustenta, visto estar bem estabelecido que um grande contingente de adipocitocinas (conjunto de fatores liberados pelo tecido adiposo), com atividades pró ou anti-inflamatória são gerados e liberados pelo tecido adiposo (BERG; OUCHI et al., 2003; SCHERER, 2005).

Diversas adipocitocinas já estão identificadas e, de acordo com suas atividades são agrupadas em adipocitocinas pró-inflamatórias (Leptina, resistina, proteina 4 ligadora de retinol, entre outras) (PRADO et al., 2009). E adipocitocinas com efeito anti-inflamatório (adiponectina, omentina, SFRP5 entre outras) (WANG, 2014).

A leptina é uma adipocitocina envolvida com o controle do gasto de energia, na atividade neuroendócrina e na função do sistema imune. Participa da maturação sexual e, diversos estudos alinham suas ações à resposta inflamatória. A leptina exerce suas ações após se acoplar a receptores, os quais, em roedores, são subdivididos em 6 isoformas e, em humanos já foram identificadas 4 isoformas (LEE 
et al., 1996; PEELMAN et al., 2006; SUN et al., 2010). No contexto do consumo de alimento e gasto energético, a leptina exerce suas ações interferindo com a atividade de grupos de neurônios localizados no sistema nervoso central, notadamente no hipotálamo (AHIMA et al., 1996; CHAN et al., 2003). No contexto imunomodulador induz a síntese de citocinas pró-inflamatórias tais como TNFa, IL-6 e fator de crescimento do tipo 1. O inverso igualmente ocorre, isto é, o TNFa e a IL-1 podem induzir aumento de concentração circulante de leptina. Ainda, a leptina estimula a geração de citocinas com perfil Th1 e pode inibir aquelas conhecidas como sendo de perfil Th2 (OUCHI et al., 2011). É interessante notar que, adipócitos de mulheres secretam mais leptina do que adipócitos de homens (ELMIMQUIST; SCHERER, 2012).

A resistina, outra adipocitocina, participa potencialmente da indução da resposta inflamatória. Evidências experimentais mostram que essa molécula, rica em cisteina, pode causar resistência à insulina. Ainda, animais deficientes de resistina apresentam baixas concentrações de glicose (BANEREJEE et al., 2004STEPPAN et al., 2001), e animais obesos (ob/ob) deficientes de resistina apresentam piora da obesidade, mas melhoram a tolerância a glicose e a sensibilidade à insulina (QI et al., 2006).

A proteína ligadora de retinol do tipo 4 - RBP4 - (vitamina A), originariamente descrita como sendo secretada por hepatócitos, também é liberada por adipócitos e macrófagos. No contexto da obesidade, sabe-se que animais deficientes de proteína transportadora de glicose, GLUT4, apresentam elevada expressão de RBP4 no tecido adiposo. Admite-se que alta expressão de RBP4 se associa à indução do estado diabético. De interesse, a administração de RBP4 em condições de normoglicemia reduz a sensibilidade à insulina e pode causar hiperglicemia (BROCH et al., 2010; YANG et al., 2005). Considerando que a RBP4 medeia a homeostasia de glicose, então elevadas concentrações de RBP4 podem causar quadros de síndrome metabólica e aumento de índice de massa corporal (GRAHAM et al., 2006). Assim, em quadros de obesidade a expressão de RBP4 pode ser utilizada como marcador de expansão de tecido adiposo e de inflamação subclínica (BALAGOPAL et al., 2007; KLOTING et al., 2007).

A adiponectina é uma citocina anti-inflamatória sintetizada pelos tecidos adiposos, células do músculo esquelético e células endoteliais. Uma de suas 
funções é aumentar a sensibilidade à insulina. Em indivíduos saudáveis ela está presente na circulação em altas concentrações e em indivíduos obesos apresenta baixa concentração, isso se deve ao fato dos níveis de TNF- $\alpha$ estarem altos, pois o mesmo reduz a produção de adiponectina (ARAÚJO; MORAES, 2011).

O tecido adiposo de indivíduos obesos apresenta aumento do número de macrófagos, polimorfonucleares, células T, B e mastócitos (GREGOR et al., 2011; NISHIMURA et al., 2009; OSBOM; OLEFSKY, 2012; YANG et al., 2010; WEISBERG et al., 2003; WINER et al., 2011;). Por causa disso, o tecido adiposo pode ser considerado como elemento importante para o desenvolvimento da inflamação crônica observada na obesidade (DIXIT; KANNEGANTI, 2012). Como mencionado existem evidências de que, a obesidade modula a geração de citocinas com perfil inflamatório $\mathrm{Th}_{1}$ e $\mathrm{Th}_{2}$ (SCHIPPER et al., 2012). Considerando: 1. que a asma é uma doença inflamatória pulmonar cujo perfil de citocinas do tipo Th1 ou Th2 está presente; 2. que existem estudos indicando o envolvimento da obesidade com a indução da asma; 3. que o tecido adiposo de mulheres secreta mais adipocitocinas. Então é interessante notar que, estudos (clínicos ou experimentais) explorando a interação dos hormônios sexuais femininos com a obesidade sobre o curso da asma, ainda não tenham sido consistentemente avaliados.

Existem estudos sugerindo que a IL-17 reduz a geração e o acúmulo de tecido adiposo. Ainda, esta citocina pode também controlar o metabolismo da glicose. Animais obesos, deficientes de IL-17, aumentam a quantidade de massa de tecido adiposo. É interessante notar que, linfócitos $T$ presentes no tecido adiposo liberam IL-17 (ZUÚÑIGA et al., 2011). É possível, portanto, que o sistema imune module o teor de tecido adiposo. Neste contexto, as repercussões deste controle para a doença inflamatória pulmonar podem ser de interesse. De fato, a IL-17 pode alterar a atividade funcional das vias aéreas na asma (CHANG et al., 2012)

Citocinas como TNF- $\alpha$ e intérferon (IFN)- $\delta$ são sintetizadas também no tecido adiposo. Por causa disto, o tecido adiposo pode exercer relevante ação no controle de respostas do organismo contra micro-organismos. De maneira geral pode-se dizer que no tecido adiposo existe um potencial perfil inflamatório ofertado pelas citocinas do tipo Th1. Outro grupo de células presentes no tecido adiposo se associa ao perfil de citocinas Th2 da resposta imune tais como macrófagos (Mo) do subtipo $2\left(\mathrm{M}_{2}\right)$, eosinófilos (Eo) e células $\mathrm{T}$ reguladoras (Treg). O perfil Th2 se 
relaciona com a geração de interleucinas (IL) IL-4, IL-10 e IL-13 e, entre outras. Vale ressaltar que, embora pouco investigado o papel dos neutrófilos na obesidade, parece estar relacionado ao fato de que estes fagócitos se ativam sistemicamente e podem migrar para o tecido adiposo (ELGAZAR-CARMON et al., 2008; NIIJHUIS et al., 2009). No conjunto, estas informações se reforçam a percepção de que a obesidade induz um estado inflamatório crônico no organismo.

Ressalte-se que a literatura sobre o papel da obesidade em mulheres asmáticas (BHATT et al., 2016; CAPELO et al., 2015; ERZURUM et al., 2015; SANTAMARIA et al., 2012; TOWNSEND et al., 2012WANG et al., 2015) é bem ampla. Todavia, dados sobre a interação da obesidade e asma no sexo feminino ainda são escassos.

1.2 Asma e obesidade: A asma é uma doença inflamatória crônica das vias aéreas na qual mastócitos, eosinófilos, neutrófilos, células dendríticas e linfócitos T exercem efeitos relevantes. Basicamente, a asma se caracteriza por episódios recorrentes de dispneia, chiado e tosse (GINA, 2015). Estes eventos estão associados (causa/efeito) à obstrução brônquica. A bronconconstrição pode ser reversível espontaneamente ou por meio de interferência farmacológica. Todavia, em algumas condições, a obstrução torna-se difícil de ser revertida na sua plenitude. Tal irreversibilidade se relaciona com a hiperplasia e hipertrofia da musculatura lisa das vias aéreas (PANETTIERI; TILIBA, 2009). Estes episódios em conjunto concorrem para o desenvolvimento da hiper-reatividade brônquica (HRB). Por definição a hiperreatividade brônquica indica a resistência de resposta broncocontritora em resposta a determinados estímulos, provocando um aumento e grau de estreitamento das vias aéreas (GINA, 2015).

A Organização Mundial de Saúde estima que, 235 milhões de pessoas no mundo tenham asma e que, em 2025 este número possa aumentar para 335 milhões, fazendo mais de 255 mil vítimas fatais por ano (GONZALES, 2016), no Brasil a incidência da asma é bastante significativa (cerca de 20 milhões de pessoas) o que causa elevada taxa de absenteísmo ao trabalho e na escola. Dados do DATASUS (2014) mostraram que a asma é a $3^{\underline{a}}$ causa de internação hospitalar gerando um custo anual à rede de saúde pública estimado em 120 milhões de reais (CAPELO et al, 2015). Muito embora seja patologia complexa e multimediada, 
existem diversos fatores que contribuem ou exacerbam seus sintomas (GINA, 2015; KIM et al., 2010). Dentre estes, a obesidade, que aumenta a incidência e a piora da patologia (SHORE, 2008). A asma e a obesidade estão ligadas fortemente por fatores genéticos e ambientais (HANCOX et al., 2014). Na prática clínica é sabido e bem estabelecido que pacientes com asma e obesidade tendem a ter um quadro de piora do controle da asma, bem como o teste de função pulmonar diminuída (O’TOOLE, 2016). Pacientes asmáticos e obesos por vezes são resistentes a terapia farmacológica por corticoides, e tendem a ter aumento de hospitalização e piora nos sintomas quando comparados com asmático não obesos. (BHATT; LAZARUS, 2016). Estudo realizado por Castro-Rodrigues (2001) demonstrou que, a diferença no ganho de peso e asma é maior em mulheres em comparação aos homens, sugerindo associação entre obesidade, asma e hormônios sexuais femininos. Assim, a oscilação da concentração circulante de hormônios sexuais femininos durante o ciclo sexual, sendo então, considerado fator de agravamento dos sintomas da asma (BONDSA; MIDORO-HORIUTI, 2013). De fato, parcela significativa de mulheres asmáticas e obesas desenvolvem uma condição definida como a asma de difícil controle, associada com uma maior gravidade da asma (CAPELO et al., 2015; ERZURUM, 2015; SKOBELOFF et al., 1996; WANG, et al., 2015).

Embora os mecanismos que medeiam a conexão entre obesidade e asma não sejam totalmente compreendidos, esta interação é bem reconhecida (TRUNKBLACKT; ULRIK, 2013). Descrita na década de 1980 (SEIDELL et al.,1986) somente nos anos 1990 é que tais conexões foram consideradas de interesse.

Subsequentemente, estudos identificaram que a obesidade pode preceder a asma (BEUTHER; SHORE; JOHNSTON, 2006; SUTHERLAND, 2007). Neste contexto, observa-se a influência que a obesidade exerce sobre a mecânica pulmonar, nas alterações de calibre das vias aéreas e na perda do efeito broncoprotetor durante a inspiração profunda. Considerando que, a obesidade pode causar um quadro de inflamação sistêmica, elevar a geração de citocinas próinflamatórias e reduzir aquelas com atividade anti-inflamatória, reforça se a existência de interação da asma com obesidade (BOULET, 2013). Esta interação sugere maior complexidade e indica que o local de deposição de tecido adiposo é mais importante (como fator de predisposição à asma) do que o alto índice de 
massa corporal (IMC). Realmente, a deposição de tecido adiposo no abdômen (obesidade abdominal) é mais preocupante para indução da asma do que o aumento da massa de gordura geral. Nesta linha de raciocínio, os estudos indicam maior risco de desenvolvimento/piora de asma em mulheres com deposição abdominal de gordura, mas não com índice de massa corporal aumentado (VON-BEHREN et al., 2009). A consequência disto é que o IMC pode não ser parâmetro representativo e fiel de risco de desenvolvimento da asma. De fato, estudos conduzidos por Brumpton et al., (2013), mostraram que homens e mulheres obesas têm risco similar para desenvolver asma. Todavia, a obesidade abdominal em mulheres mostrou ser fator de risco adicional. Nesse contexto, é interessante notar que dos diversos estudos que investigam a correlação asma e obesidade em mulheres não avaliam o tipo de participação que os hormônios sexuais femininos podem exercer. Soma-se a isto, que está bem estabelecida a complexa interação do estradiol e da progesterona na modulação da asma (ERZURUM et al, 2015; TAM et al., 2011; TOWNSEND et al., 2012; WANG et al., 2015;). Tomados em conjunto, estes dados permitem supor a existência de algum mecanismo endógeno modulados pelos hormônios sexuais femininos, de maneira a mediar a conexão obesidade/asma. Em reforço a estas observações, células do sistema imune e da musculatura lisa das vias aéreas são sensíveis aos efeitos dos hormônios sexuais femininos (OERLELT-PRIGIONE, 2012) existem estudos mostrando que o estradiol induz liberação de leptina (GEBER et al., 2012).

Como mencionado, os mecanismos orquestradores desta interação (obesidade/asma) não são totalmente conhecidos. Apesar disso, existem dados sugerindo que ambas as condições (asma e obesidade) compartilham etiologias similares. Demais, a obesidade reduz a capacidade do volume residual e do volume corrente, o que compromete a qualidade da mecânica pulmonar. Sob o ponto de vista inflamatório, é digno de nota que o tecido adiposo do indivíduo obeso aumenta a geração de citocinas pró-inflamatórias (IL-1 $\beta$, IL-6, IL-8, TNF- $\alpha$ ) e de leptina, em detrimento da síntese de citocinas anti-inflamatórias (IL-10) e de adiponectina (LUMENG; SHORE, 2007; SALTIEL, 2011). De interesse, é que a hiperreatividade das vias aéreas em animais obesos se relaciona com o grau de aumento de massa corpórea. Nesse sentido, os estudos mostram que animais que incrementam $45 \%$ de massa corpórea desenvolvem hiperreatividade das vias aéreas. Embora identificada, 
os mecanismos subjacentes à indução desta hiperreatividade em animais obesos ainda não foram totalmente elucidados. Nesse sentido, e tendo em mente o papel da leptina na obesidade, existem estudos indicando que esta adipocitocinas medeia a hiperreatividade das vias aéreas (CAPELO et al., 2015; DIXON et al., 2016; HANCOX et al., 2014; JOHNSTON et al., 2007; SHORE et al., 2008). Shore et al., (2005) demonstraram que a leptina medeia a indução da hiperreatividade das vias aéreas na vigência da inflamação alérgica pulmonar em animais não obesos. Hancox et al., 2014 demonstraram que a leptina é diretamente proporcional ao nível de obesidade, mostrando que o lavado broncoalveolar de indivíduos asmáticos e obesos tem níveis aumentados de leptina. De acordo com estes autores, a leptina estabelece conexão entre a obesidade e a asma. Porém, o mecanismo como isto ocorre ainda não foi definido.

No contexto da interação obesidade/asma, Calixto et al., (2010), usando modelo murino de inflamação pulmonar alérgica, mostraram que, a obesidade aumenta o número de eosinófilos na medula óssea e prolonga o seu tempo de permanência na região brônquica e bronquiolar. Este evento foi associado à redução do número de eosinófilos recuperados no líquido de lavado broncoalveolar (LBA) e é aparentemente mediado por eotaxina, TNF e IL-10. Vale lembrar que animais obesos alérgicos tiveram aumento da concentração no soro de leptina e redução de adiponectina. Lintomen et al., (2012), obtiveram dados similares em camundongos obesos (ob/ob) alérgicos. Neste sentido, estes autores mostraram que camundongos ob/ob alérgicos apresentam marcante aumento de trânsito de eosinófilos da medula óssea para o espaço brônquico e um atraso para o compartimento alveolar. Ye et al., (2012), reforçaram que a obesidade se associa à indução de doença respiratória. Estes autores mostraram que camundongos neonatos com dietas em excesso de lipídios, desenvolveram hiperreatividade das vias aéreas na fase adulta, além de remodelamento pulmonar e aumento da geração de citocinas inflamatórias no pulmão. Portanto, a obesidade pode aumentar a suscetibilidade à doença pulmonar, notadamente a asma. Aparentemente estes eventos decorrem da produção exacerbada de citocinas inflamatórias por macrófagos pulmonares (FARZAN, 2013; HALDAR, 2008).

Haldar et al., (2008) mostraram que mulheres obesas asmáticas apresentam piora de alguns parâmetros associados a asma. Neste contexto, estes autores 
observaram desenvolvimento ainda tardio de asma e redução da concentração de NO exalado. Ainda moderada hiperreatividade brônquica, reversibilidade de fluxo expiratório forçado em 1 segundo (FEV1). De interesse, esta piora dos sintomas da asma se associou a um perfil inflamatório neutrofílico. Apesar deste estudo, de maneira geral, os dados existentes referem-se a análises retrospectivas e prospectivas e tendências de risco para o desenvolvimento de asma em mulheres obesas (SOOD et al., 2012). Estudos sugerem que a asma e a obesidade parecem estar ligadas por dois fenótipos: um fenótipo definido como asma primária (atópica) que é agravada pela obesidade e um segundo fenótipo definido como asma grave de início tardio (não atópica). A asma não atópica é conhecida na clínica como a asma de difícil controle e afeta predominantemente mulheres. Este fenótipo se associa a inflamação neutrofílica e com os efeitos da obesidade no pulmão (KAZUYUKI, et al., 2012; RASMUSSENA, et al., 2014). É digno de nota, a alta prevalência de obesidade em mulheres com a asma neutrofílica. Estudos experimentais que investigam a patogênese da asma na obesidade sugerem que a obesidade medeia um tipo de asma com menor perfil Th2 e maior perfil Th1. Como consequência observa-se um tipo de asma com fenótipo diferente da asma alérgica. Admite se que o perfil Th1 na asma é determinado por um fenótipo diferente daquele observado na asma de perfil TH2, mais comum em mulheres, com início tardio e baixos níveis de marcadores alérgico atópica de inflamação (CALIXTO et al., 2013). Vale lembrar que, os eosinófilos ocupam lugar de destaque na asma atópica enquanto na asma não atópica, os neutrófilos exercem efeitos moduladores relevantes. A asma atópica (alérgica) é caracterizada como uma resposta imunitária de perfil Th2, no qual a IL-4, IL-5 e IL-13 são potentes mediadores de fenótipos como, eosinofilia, muco, lesão epitelial e/de remodelamento brônquico. Em contraste, linfócitos Th17 parecem mediar os eventos associados ao fenótipo da asma não atópica (ou asma neutrofílica). Nesta condição a resposta Th1 medeia a geração de citocinas tais como IL-8 e IL-17 (KIM et al., 2013). Aliás, quantidades exuberantes de IL-17 são detectáveis no pulmão de pacientes com asma neutrofílica. Soma-se a isto que, a IL-17 pode aumentar o número de células epiteliais e a geração de eotaxina. É interessante notar que, a eotaxina exerce importante papel na indução do recrutamento e ativação de eosinófilos (CHESNE et al., 2014). Portanto, a IL-17 regularia o equilíbrio eosinófilo/neutrófilo presentes no 
pulmão de indivíduos asmáticos. Apesar do mencionado, neutrófilos medeiam a patogênese da asma não atópica. A IL-8 também recruta neutrófilos, e sua expressão nas células da musculatura lisa das vias aéreas pode induzir aumento de migração de neutrófilos nos asmáticos (TAKAGl et al., 2014).

No contexto dos moduladores da asma, a oscilação da concentração circulante de hormônios sexuais femininos durante o ciclo sexual ocupa lugar de destaque. O grau de interferência dessas interações sobre a asma depende da faixa etária em que se desencadeia a puberdade ou a pós-menopausa. Estudos sugerem que os hormônios sexuais femininos possam estar envolvidos na regulação de receptores $\beta_{2}$ adrenérgicos, e que estes receptores possam ser regulados por estradiol e progesterona, modulando a resposta broncodilatadora, no entanto, no período da menopausa estes hormônios cessam ocorrendo uma piora na asma (ERZURUM et al., 2015). A percepção de que os hormônios sexuais femininos modulam a asma é também identificada em modelos experimentais, notadamente de inflamação pulmonar alérgica. Os dados disponíveis sugerem que o estradiol e a progesterona medeiam ações protetoras ou indutoras dos sintomas da asma (DE OLIVEIRA et al., 2007; LIGEIRO DE OLIVEIRA et al., 2013; RIFFO-VASQUEZ et al., 2007; TAKEDA et al., 2013). De forma geral, nestes estudos o papel dos hormônios sexuais femininos é avaliado por meio da remoção dos ovários (OVx) em roedores (camundongos e ratos) tornado alérgicos. Basicamente, os animais são sensibilizados com um determinado antígeno e posteriormente submetidos ao desafio antigênico.

Estudo realizado por 25 anos demonstrou que, a obesidade é um forte preditor de asma em mulheres. Neste estudo observou-se que há diferenças significativas na gravidade da asma entre indivíduos obesos e não obesos. Em essência, á contagem de neutrófilos no lavadobroncoalveolar e os percentuais de neutrófilos no escarro foram maiores em pacientes obesos quando comparados com os de asmáticos não obesos (CAPELO, et al., 2015). Ainda, observou se que o aumento nos percentuais de neutrófilos no escarro correlacionou, positivamente, com índices de massa corporal nas mulheres asmáticas. Ainda, a prevalência de asma neutrofílica foi significativamente maior em mulheres obesas quando comparada com a de pacientes não obesas (KIM, et al., 2014). À luz destas evidências, os estudos que ora propomos, considera investigar a interação da 
obesidade com a inflamação pulmonar neutrofílica, visando a contribuir para a compreensão da asma de difícil controle em mulheres obesas. Para tanto, o fio condutor deste estudo foi investigar o curso da inflamação pulmonar neutrofílica, na vigência da obesidade, em camundongos fêmeas. Nesse sentido, o estudo poderá fornecer subsídios para a compreensão dos mecanismos que medeiam a piora da inflamação pulmonar neutrofílica em mulheres obesas. 


\section{JUSTIFICATIVA}

A obesidade é uma condição que se associa ao desenvolvimento da asma e aparentemente mulheres obesas são mais suscetíveis. A obesidade atingiu patamares elevados no mundo e, no Brasil vem recebendo atenção especial das autoridades, visto a crescente elevação de suas taxas.

No cenário da asma, mulheres com IMC acima de 30 relatam piora dos sintomas da asma durante o período pós-menopausa. Notadamente, esta piora é denominada asma neutrofílica, conhecida como asma de difícil controle, e caracterizada por ineficácia dos corticoides e altas doses de broncodilatadores inalatórios

Estudos recentes indicam a obesidade como um dos fatores envolvidos com fenótipo que caracteriza a asma. Todavia, dados sobre a interação da obesidade com asma neutrofílica ainda são escassos ou não estão disponíveis.

A presente proposta visa apresentar em primeiro lugar um enfoque adicional à investigação da obesidade em camundongos fêmeas com asma neutrofílica. Os estudos terão como base a avaliação da repercussão da obesidade induzida por uma dieta rica em lipídios e a inflamação pulmonar tardia (ou asma de difícil controle) previamente instalada em camundongos fêmeas obesas.

Nesse sentido, o estudo poderá fornecer subsídios para a compreensão dos mecanismos que medeiam à asma neutrofílica e obesidade em mulheres. O impacto social da proposta recai sobre sua potencial contribuição para inserção de alternativas terapêuticas para o controle da asma não atópica em mulheres obesas. 


\section{HIPÓTESE}

A interação da obesidade com a asma acarreta um fenótipo de asma conhecido como asma neutrofílica que se associa à piora da inflamação pulmonar. 


\section{OBJETIVOS}

\subsection{Objetivo Geral:}

Avaliar o fenótipo da inflamação pulmonar e a mecânica respiratória em camundongos fêmeas obesas na vigência da asma experimental neutrofílica.

\subsection{Objetivo Específico}

1. Caracterizar o modelo de obesidade.

2. Caracterizar o modelo de asma neutrofílica.

3. Validar farmacologicamente o modelo de asma neutrofílica.

4. Estabelecer o papel da obesidade sobre a inflamação neutrofílica, mecânica respiratória e geração de mediadores no pulmão de animais obesos e não obesos submetidos a asma experimental. 


\section{MATERIAIS E MÉTODOS}

\subsection{ANIMAIS}

Foram utilizados camundongos Balb/C fêmeas (20-25 g), provenientes do Biotério do Departamento de Farmacologia do ICB/USP. Os animais foram mantidos em ciclo claro/escuro de 12 horas, em condições padrão de alimento e água ad libitum. Os animais foram mantidos no Biotério em gaiolas de polipropileno, medindo $30 \times 19 \times 13 \mathrm{~cm}$, forradas com maravalha, alojadas em estantes. O estudo foi iniciado após aprovação da Comissão de Ética no Uso de animais do Instituto de Ciências Biomédicas da Universidade de São Paulo ICB/USP (015/2014/CEUA). 


\subsubsection{Regime alimentar com dieta hiperlipídica e determinação do ganho de massa}

Os animais do grupo controle receberam ração convencional (Nuvilab CR-1) contendo milho integral moído, farelo de soja, farelo de trigo, carbonato de cálcio, fosfato bicálcico, cloreto de sódio, premix vitamínico mineral e aminoácidos.

Os animais do grupo obeso receberam dieta hiperlipídica (Pragsoluções Biociências) por 10 semanas com a seguinte composição (g) para cada 1 quilo de ração conforme ilustrado na tabela abaixo. Os animais foram pesados e o consumo de ração calculado semanalmente para a avaliação da evolução ponderal.

Tabela 1 - Tabela nutricional com quantidade de calorias, proteínas e lipídios para ração convencional e ração hiperlipídica.

\begin{tabular}{|c|c|c|c|c|}
\hline \multirow{2}{*}{ INGREDIENTES } & \multicolumn{2}{|c|}{ Dieta Convencional } & \multicolumn{2}{|c|}{ Dieta Hiperlipídica } \\
\hline & $\mathrm{g} / \mathrm{KG}$ & Kcal & $\mathrm{g} / \mathrm{Kg}$ & Kcal \\
\hline Amido de milho & 415,0 & 1.660 & 14,3 & 57,2 \\
\hline Farelo de Soja & 305,0 & 1.281 & 410,0 & 1.722 \\
\hline Sacarose & 80,0 & 320 & 80,0 & 320 \\
\hline Maltodextrina & 70,0 & 280 & 60,0 & 280 \\
\hline Banha & 0,0 & 0 & 302,0 & 2.718 \\
\hline Óleo de Soja & 0,0 & 0 & 0,0 & 0 \\
\hline Ac. Graxo & 50,0 & 350 & 45,0 & 300 \\
\hline Celulose micro. & 31,7 & 0 & 25,4 & 0 \\
\hline L-Cistina & 1,8 & 7,2 & 1,8 & 7,2 \\
\hline Cloreto colina & 1,5 & 0 & 1,5 & 0 \\
\hline $\begin{array}{l}\text { Butil- } \\
\text { hidroxitolueno }\end{array}$ & 0,014 & 0 & 0,028 & 0 \\
\hline Mix Vit. & 10,0 & 40 & 10,0 & 30 \\
\hline Caseína & 0 & 0 & 5,0 & 10 \\
\hline Mix. Mineral & 35,0 & 0 & 35,0 & 0 \\
\hline Sacarose & 0 & 0 & 10 & 50 \\
\hline Total & 1000,0 & 3.938 & 1000,00 & 5.494 \\
\hline $\begin{array}{l}\text { Fonte } \\
\text { Carboidratos }\end{array}$ & \multicolumn{2}{|c|}{$73,9 \%$} & \multicolumn{2}{|c|}{$26,13 \%$} \\
\hline Fonte Proteína & \multicolumn{2}{|c|}{$14,8 \%$} & \multicolumn{2}{|c|}{$14,4 \%$} \\
\hline Fonte Lipídio & \multicolumn{2}{|c|}{$9,8 \%$} & \multicolumn{2}{|c|}{$57,6 \%$} \\
\hline
\end{tabular}




\subsubsection{Avaliação da quantidade de tecido adiposos retro peritoneal e tecido adiposo gonadal}

Ao término da $10^{\underline{a}}$ semana, os animais foram anestesiados com cetamina (100 mg/kg) e xilazina $(20 \mathrm{mg} / \mathrm{kg}$ ) por via intraperitoneal e abertos pela região peritoneal de modo a permitir exposição e retirada do tecido adiposo retroperitoneal e gonadal (FILHO et al., 2004). Após retirada, o total de tecido adiposo foram quantificado em balança eletrônica, Marte (modelo ASF11).

\subsubsection{Avaliações Séricas}

Os animais permaneceram em jejum de 12 horas, e então foram anestesiados e o sangue foi coletado por meio da veia jugular. A partir das amostras de sangue foram avaliados os níveis séricos de colesterol total (CT), (colesterol Liquiform, Labtest Diagnóstica S.A., Brasil), HDL-colesterol (HDL LE, Labtest Diagnóstica S. A., Brasil) e Triglicérideos (TG) (Triglicerideos Liquiform, Labtes Diagnóstica S. A., Brasil), de acordo com o método estabelecido pelo fabricante. 


\subsection{Modelo de inflamação pulmonar}

\subsubsection{Indução da inflamação pulmonar neutrofílica}

Os animais foram sensibilizados pela injeção subcutânea de ovoalbumina (OVA, Grau V, Sigma Co. St.Louis) adsorvida em adjuvante completo de Freund). Após 21 dias da sensibilização os animais foram desafiados por via intranasal (i.n) 1 vez ao dia, durante 3 dias consecutivos com ovoalbumina grau II (OVA, Grau II, Sigma Co. St.Louis). Como controle foram utilizados animais submetidos à falsa imunização e desafio com PBS pelas mesmas vias do grupo experimental.

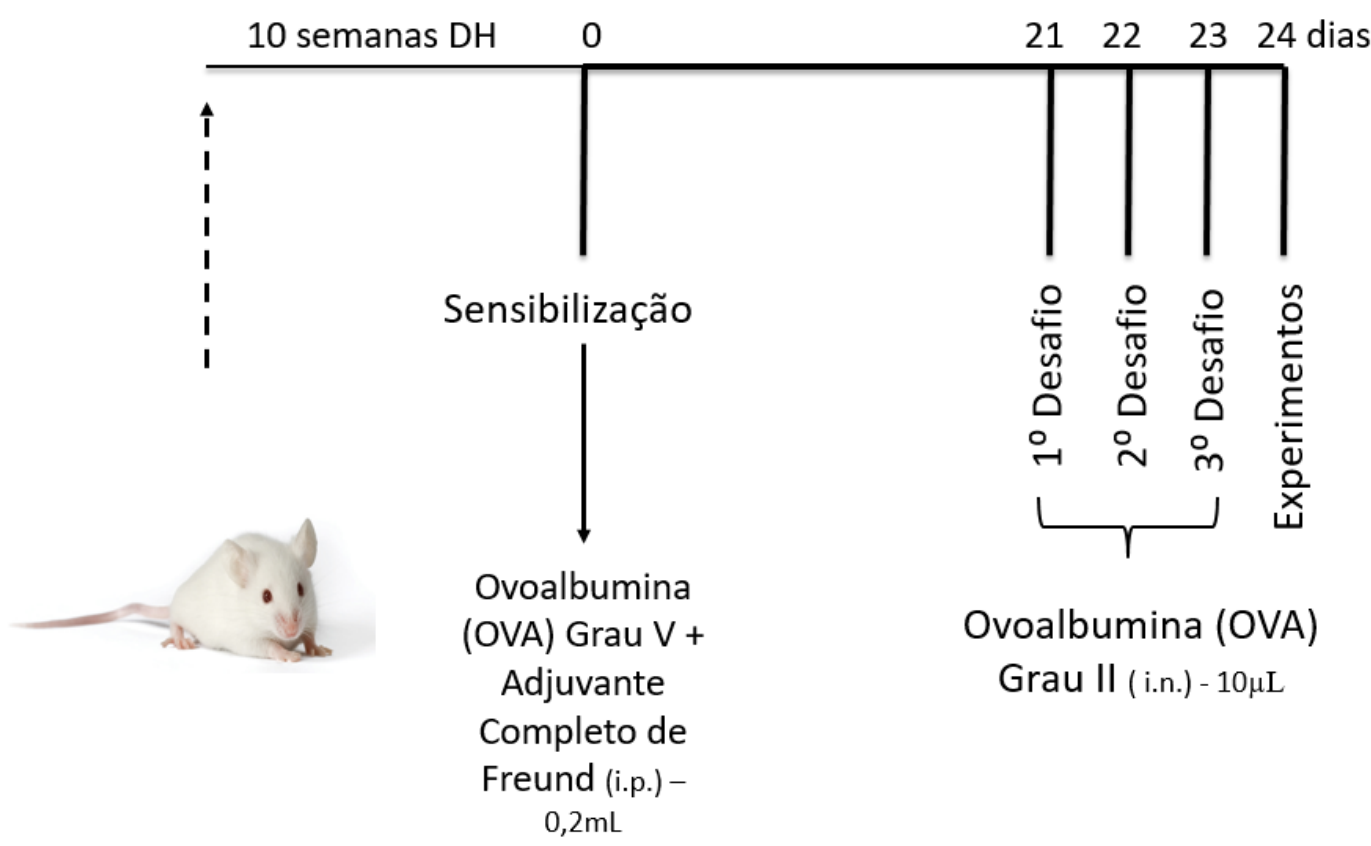

Figura 1 - Os grupos consistiram de animais que receberam dieta convencional (DC) proveniente do Biotério do Departamento de Farmacologia do Instituto de Ciências Biomédicas da Universidade de São Paulo e animais que receberam dieta hiperlípidica (DH), ambas por 10 semanas. Após estes períodos, foram divididos em animais não sensibilizados e não desafiados para o grupo controle, animais sensibilizados e desafiados com ovoalbumina (OVA + Adjuvant de Freund para asma neutrofílica) $(0,2 \mathrm{~mL}$ i.p), foi realizado 3 desafios com 24 horas de intervalo com 
OVA Grau II (10 $\mu \mathrm{L}$ i.n.) e após 24 horas do último desafio experimentos foram realizados, para tanto foram utilizados camundongos femeas.

\subsubsection{Indução da inflamação pulmonar eosinofílica}

Os animais foram sensibilizados pela injeção subcutânea de ovoalbumina (OVA, Grau V, Sigma Co. St.Louis) adsorvida em hidróxido de alumínio, $\left(\mathrm{Al}(\mathrm{OH})_{3}\right)$ $0,2 \mathrm{~mL}$. Após 7 dias da sensibilização os animais receberam reforço por via subcutânea com respectivas soluções de OVA e $\mathrm{Al}(\mathrm{OH})_{3}, 0,2 \mathrm{~mL}$. Decorrido 14 dias após da primeira sensibilização os animais foram desafiados por via intranasal com

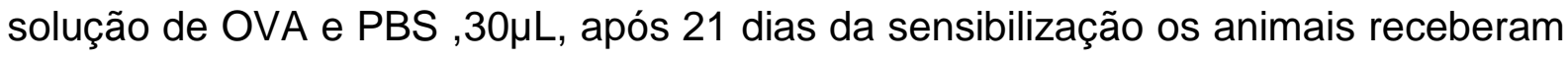
um $2^{\circ}$ desafio e após 1 dia um $3^{\circ}$ desafio por via (i.n.) com OVA e PBS, 30 $\mu$ L (i.n.). Como controle foram utilizados animais submetidos a falsa imunização e desafio com PBS pelas mesmas vias do grupo experimental.

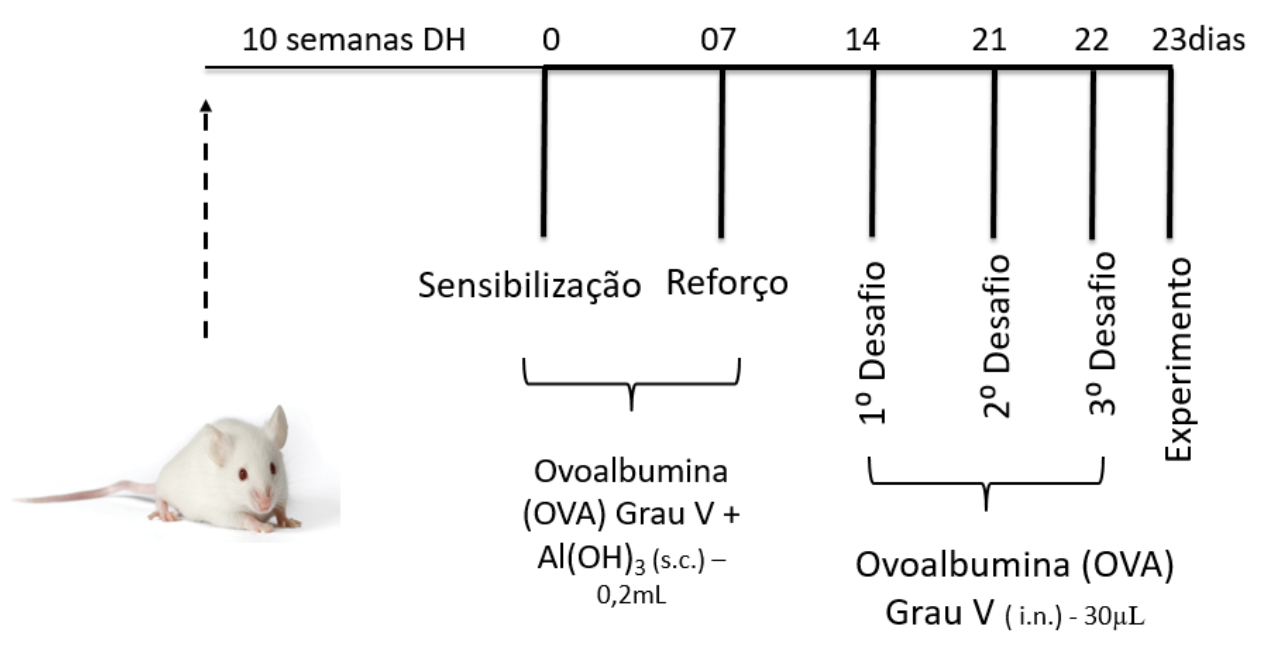

Figura 2 - Os grupos consistiram de camundongos fêmeas, após ambientalização de 10 semanas no biotério os animais foram sensibilizados por injeção subcutânea de ovoalbumina OVA adsorvida em hidróxido de alumínio, $\mathrm{Al}(\mathrm{OH})_{3}$ 0,2 $\mathrm{mL}$. Após 7 dias da sensibilização os animais receberam reforço por via subcutânea com respectivas soluções de OVA e $\mathrm{Al}(\mathrm{OH})_{3}, 0,2 \mathrm{~mL}$. 14 dias após a primeira sensibilização os animais foram desafiados por via i.n. com solução de OVA e PBS , 
$30 \mu \mathrm{L}$, após 21 dias da sensibilização os animais receberam um $2^{\circ}$ desafio e após 1 dia um $3^{\circ}$ desafio por via (i.n.) com OVA e PBS, $30 \mu \mathrm{L}$ (i.n.) Os experimentos foram realizados após 24 horas do último desafio.

\subsubsection{Tratamento Farmacológico}

Os animais foram tratados previamente 01 hora aos desafios com budesonida (Pulmicort, Astra Zeneca, 0,25 mg/mL). Foram administrados $100 \mu \mathrm{g} / \mathrm{Kg}$ por via intranasal, sob anestesia com isoflurano (Cristália, 5\% de isoflurano em $50 \%$ de oxigênio) por via inalatória utilizando anestesiador para pequenos animais (Vaporizer for isoflurane anesthetic, model 100 vaporizer - Surgi Vet). Como controle foram utilizados animais submetidos a falso tratamento farmacológico com PBS pelas mesmas vias do grupo experimental.

\subsection{Determinação do número de células recrutadas para o pulmão}

\subsubsection{Lavado broncoalveolar (LBA)}

As células presentes no espaço broncoalveolar foram obtidas a partir do LBA (Riffo-Vasquez et al., 2000). Para tanto, 24 h após o último desafio, os animais foram anestesiados com excesso de cetamina (300 mg/kg) e xilazina $(60 \mathrm{mg} / \mathrm{kg}$ ) ip. A cavidade peritoneal foi exposta para realização da exsanguinação por meio da secção da aorta abdominal. A seguir, foi feita incisão longitudinal na região cérvicoventral, a traquéia foi exposta e canulada com um tubo de polietileno acoplado a uma seringa de plástico. O LBA foi realizado injetando 1,6 $\mathrm{ml}$ de PBS fracionando 2 vezes. A amostra foi centrifugada, por $10 \mathrm{~min}$ a $1500 \mathrm{rpm}$. O sobrenadante desprezado e o botão celular ressuspenso em $1 \mathrm{ml}$ de PBS.

A contagem do número total de células foi realizada em câmara de Neubauer e a contagem diferencial feita por microscopia óptica comum e contadas no mínimo 400 células, diferenciando-as segundo o tipo celular (células mononucleares, neutrófilos e eosinófilos). A contagem total foi feita em alíquotas da amostra (90 $\mu \mathrm{l})$ acrescidas de $10 \mu \mathrm{l}$ de cristal violeta $(0,2 \%)$ dissolvidos em ácido acético (30\%). Para a contagem diferencial das células, alíquotas da amostra (100 $\mu \mathrm{l}$ ) foram colocadas em Citospin ${ }^{\circledR}$ (Fanem) e centrifugadas a 1.000 rpm por 5 min. As lâminas obtidas foram coradas com Instant Prov (Neuprov $\left.{ }^{\circledR}\right)$. 


\subsubsection{Avaliação da atividade pulmonar de mieloperoxidase (MPO) e eosinoperoxidase (EPO)}

Decorridas $24 \mathrm{hs}$ do último desafio, os animais foram anestesiados com excesso de anestésicos, submetidos à laparotomia mediana e feita a exsanguinação pela secção da aorta abdominal. A cavidade torácica foi aberta e o leito vascular pulmonar perfundido com $5 \mathrm{ml}$ de PBS por meio de uma cânula inserida na artéria pulmonar. As amostras do tecido pulmonar foram extraídas, pesadas e homogeneizadas em $1 \mathrm{ml}$ de tampão fosfato $\mathrm{pH} 6.0$ contendo $0.5 \%$ de brometo de hexadecil-tri-metil-amônio (HTAB) e $5 \mathrm{mM}$ de ácido etilenodiamino tetra-acético (EDTA) em homogeinizador tecidual (Medic Tools ${ }^{\circledR}$ ) durante 20 s. A seguir as amostras foram centrifugadas a $12.500 \mathrm{rpm}$ durante $10 \mathrm{~min}$ a $4 \stackrel{\circ}{\circ} \mathrm{e}$ o sobrenadante obtido utilizado para determinar a atividade de MPO. O ensaio da atividade da enzima mieloperoxidase pulmonar foi realizado adicionando-se, em duplicata, $10 \mu \mathrm{l}$ da amostra em cada poço dum uma placa de 96 poços. Em seguida, a reação foi iniciada pela adição de $200 \mu \mathrm{l}$ de tampão substrato, composto por tampão fosfato pH 6.0, peróxido de hidrogênio $(0.1 \%$ ) e Orto-dianisidina (1.25\%). Decorridos $5 \mathrm{~min}$, a reação foi interrompida adicionando-se $50 \mu \mathrm{l}$ de azida sódica (1\%). A leitura da absorbância foi realizada em leitor de ELISA (Bio-Tek Instruments ${ }^{\circledR}$ ) em comprimento de onda de $450 \mathrm{~nm}$ e os valores de absorbância expressos em atividade de MPO por mg de tecido.

Para determinar atividade de eosinoperoxidase (EPO), o pulmão dos animais foi removido e seu leito vascular perfundido como descrito anteriormente. A seguir, as amostras foram homogeneizadas em solução tamponada com fosfato (PBS) $5 X$ (1,9 ml/100mg de tecido). Isto feito, as amostras foram centrifugadas (12.000 rpm) durante 10 min a $4{ }^{\circ} \mathrm{C}$. O sobrenadante foi descartado e o botão celular processado. Inicialmente traços de sangue serão eliminados adicionando tampão lise $(1,5 \mathrm{ml}$ para cada $100 \mathrm{mg}$ de tecido) composto de solução de $\mathrm{NaCl}(0,2 \%$, tampão lise hipotônico), seguido por uma adição (30 s) de igual volume de solução contendo $\mathrm{NaCl}(1,6 \%$ e $5 \%$ de glicose). Esta solução foi homogeneizada novamente. Feita a homogeneização a amostra foi centrifugada (12.000 rpm) durante 10 min a $4{ }^{\circ} \mathrm{C}$. $\mathrm{O}$ sobrenadante novamente foi desprezado e o botão celular ressuspenso em brometo de hexadecil-tri-metil-amónio (0,5\%) em PBS pH 7,4 (em 1: 1,9 ml para cada $100 \mathrm{mg}$ de tecido). Uma nova homogeneização foi realizada. A seguir, foi feita a 
transferência de $500 \mu \mathrm{l}$ da amostra homogeneizada para um tubo plástico de 1,5 ml. Uma vez no tubo plástico, a amostra passou por 3 ciclos de congelamento nitrogênio $\left(\mathrm{N}_{2}\right)$ líquido e descongelamento em água corrente e armazenada a $-20{ }^{\circ} \mathrm{C}$. O ensaio foi realizado de acordo com o que segue: As amostras congeladas foram novamente centrifugadas (12.000 rpm) durante $10 \mathrm{~min}$ a $4{ }^{\circ} \mathrm{C}$ e o sobrenadante foi utilizado para realização do ensaio. O ensaio foi realizado adicionando $75 \mu \mathrm{l}$ de cada amostra +75 ul de substrato à placa plástica de 96 poços. Incubado a temperatura de $20{ }^{\circ} \mathrm{C}$ durante $30 \mathrm{~min}$ em local escuro. Paralisou-se a reação pela adição de $50 \mu \mathrm{l}$ de $\mathrm{H}_{2} \mathrm{SO}_{4} 1$ M (Tampão Stop"). A leitura da absorbância das amostras foi realizada em leitor de ELISA (492 nm).

\subsubsection{Determinação da concentração de $\lg G$ e $\lg E$}

Amostras de LBA e de soro foram utilizadas para determinação das concentrações de imunoglobulinas ( $\lg G$ e $\lg E$ ) por meio de "kits" (affymetrix eBioscience $\AA^{\circledR}$,Vienna, Austria). Os ensaios foram conduzidos seguindo orientação do fabricante. A leitura da absorbância foi realizada em leitor de ELISA (Bio-Tek Instruments ${ }^{\circledR}$ ) em comprimento de onda de $450 \mathrm{~nm}$ e os valores de absorbância expressos em concentração de $\lg G$ e $\lg E$.

\subsubsection{Quantificação de mediadores inflamatórios}

As citocinas em analise foram extraídas do (LBA) dos animais e foram quantificadas por MULTIPLEX, por meio de Kits Duo Set disponíveis comercialmente (R \& D System). Em síntese, o filtro de placa de 96 poços foi lavado com Bioplex Assay Buffer (Bio Rad, Hercules, CA). Em seguida foram adicionadas as "beads" conjugadas com anticorpos anti citocinas, lavadas com "Bioplex Wash Buffer", sendo posteriormente adicionadas as amostras. Seguido de uma incubação de $2 \mathrm{~h}$, a placa foi novamente lavada com o "Bioplex Wash Buffer", sendo então adicionado a cada poço o anticorpo de detecção biotinilado para um epítopo diferente da citocina, formando então um sanduiche de anticorpos, incubados por $1 \mathrm{~h}$. Após esse período, novas lavagens com o "Bioplex Wash Buffer" foram realizadas, sendo então adicionadas etreptavidina conjugada com PE, que se liga ao anticorpo biotinilado, por $30 \mathrm{~min}$. Novas lavagens foram realizadas e as "beads" foram resuspensas com 
Bioplex Assay Buffer e analisadas no Bioplex 200 Suspension Array System/ Luminex (Bio Rad, Hercules, CA) por meio de software Bioplex Manager, versão 4.1 (Bio Rad, Hercules, CA). Os dados apresentados são referentes no mínimo 100 beads por citocinas. Os ensaios foram conduzidos seguindo as especificações do fabricante.

\subsection{Análise histológica e morformétricos do pulmão}

Estes estudos foram realizados em colaboração com a Dra. Carla Máximo Prado do Departamento de Ciências Biológicas Universidade Federal de São Paulo (UNIFESP/DIADEMA). Os pulmões foram fixados em solução de formaldeído a 10\% por $24 \mathrm{hs}$ e, posteriormente foram transferidos para uma solução de etanol $70 \%$. 0 material foi então submetido às técnicas histológicas habituais com parafina para obtenção de cortes de $4 \mu \mathrm{m}$ de espessura e foram submetidos às seguintes colorações:

5.4.1 Coloração de Picro-Sírius - Estas colorações foram utilizadas para a contagem das fibras colágenas e elásticas, respectivamente, na parede das vias aéreas e no tecido pulmonar. A quantificação de fibras colágenas e elásticas no pulmão foi realizada no analisador de imagens, onde a medida de densidade óptica é o método empregado para detecção das fibras. Os resultados foram expressos em porcentagem de área de fibras positivas em relação à área da parede da via aérea ou no tecido pulmonar (PRADO et al.,2006).

5.4.2 Hematoxilina e Eosina - Esta coloração foi utilizada para avaliação do espessamento da camada muscular lisa e também da área de epitélio brônquico. Por análise de imagem, como descrito anteriormente, foi manualmente delimitado a área de parede da via aérea e também a área de epitélio brônquico. Estes valores foram corrigidos pelo comprimento da membrana basal que também foi medido no analisado de imagens. Foram analisados de 3 a 5 vias aéreas escolhidas aleatoriamente. 


\subsection{Avaliação da mecânica pulmonar}

Os animais foram anestesiados com cetamina $(144 \mathrm{mg} / \mathrm{kg})$ e xilazina $(13,8$ $\mathrm{mg} / \mathrm{kg}$ ), por via intraperitoneal e permaneceram nesta condição durante todo o procedimento. A cirurgia consistiu de uma incisão na região centro-escapular para posterior traqueostomia com uma cânula metálica de $0,838 \mathrm{~mm}$ de diâmetro interno e 12,7 mm de comprimento. A veia jugular direita também foi dissecada para inserção de cateter de polietileno. Encerrado o procedimento cirúrgico, o animal foi conectado ao aparelho de ventilação mecânica para pequenos animais (flexiVent, SCIREQ ${ }^{\circledR}$ Montreal, Kebec, Canadá) e submetido aos seguintes parâmetros de ventilação pulmonar: volume corrente, $10 \mathrm{ml} / \mathrm{kg}$; frequência, 150 ciclos/ minuto e PEEP (positive end-expiratory pressure), $3 \mathrm{~cm} / \mathrm{H}_{2} \mathrm{O}$. Em seguida o animal recebeu uma dose de pancurônio (Pancuron®), $1 \mathrm{mg} / \mathrm{kg}$, por via intraperitoneal.

Após sete minutos da injeção de pancurônio foi injetado, pela cânula inserida na veia jugular direita, $20 \mu \mathrm{L} / 10 \mathrm{~g}$ de peso de camundongo de uma solução de Phosphate-buffered saline (PBS) e em seguida foi realizada uma curva doseresposta para metacolina (MCh), um agonista de receptor muscarínico, nas seguintes doses: 30, 100, 300 e 1000 $\mathrm{g} / \mathrm{kg}$ (através da cânula inserida na veia jugular direita). Os parâmetros avaliados foram: resistência de vias aéreas, resistência do parênquima e elastância do parênquima pulmonar. Para a obtenção dos dados de resistência das vias aéreas, resistência de parênquima e elastância do sistema respiratório total, foi utilizado 0 modelo de fase constante (multicompartimental), descrito por Hantos et al., (1992), considera o sistema respiratório como dois compartimentos (via aérea e tecido pulmonar), onde se permite avaliar a resistência e elastância do tecido pulmonar e das vias aéreas separadamente. Para o modelo de fase constante foi utilizada a equação proposta por Hantos:

$$
Z_{r s}(f)=R_{a w}+i \cdot 2 \cdot \pi \cdot f \cdot I_{a v}+\frac{G_{t i s}-i \cdot H_{\text {tis }}}{(2 \cdot \pi \cdot f)^{\propto}}
$$

onde $Z_{r g}(f)$ é a impedância da via aérea em função da frequência, $R_{\text {av }}$ é a resistência das vias aéreas, $i$ é a unidade imaginária, $f$ é a frequência, $I_{\text {aw }}$ é a inertância das vias aéreas, $G_{\text {tis }}$ caracteriza a dissipação de energia no tecido pulmonar (resistência do tecido pulmonar), $H_{\text {tis }}$ caracteriza a energia acumulada no tecido pulmonar (elastância do tecido pulmonar) e 


$$
\alpha=\frac{2}{\pi} \cdot \arctan \left(\frac{H_{t i s}}{G_{t i s}}\right)
$$

onde é o arco-tangente. Neste estudo avaliamos, pelo modelo de fase constante, a $R_{\text {avs }}$ (resistência das vias aéreas sem interferência do tecido pulmonar), $G_{\text {tis }}$ (resistência do tecido pulmonar) e $H_{\text {tiss }}$ (elastância do tecido pulmonar).

Findo o experimento, o animal foi submetido à eutanásia por meio da secção da aorta abdominal (dessangramento) e então desconectado do aparelho. Os dados foram capturados e analisados pelo software flexiVent, versão 5.2.

Figura 3 - Fotografias do flexi-Vent para protocolo de MCh via i.v. e aquisição de dados
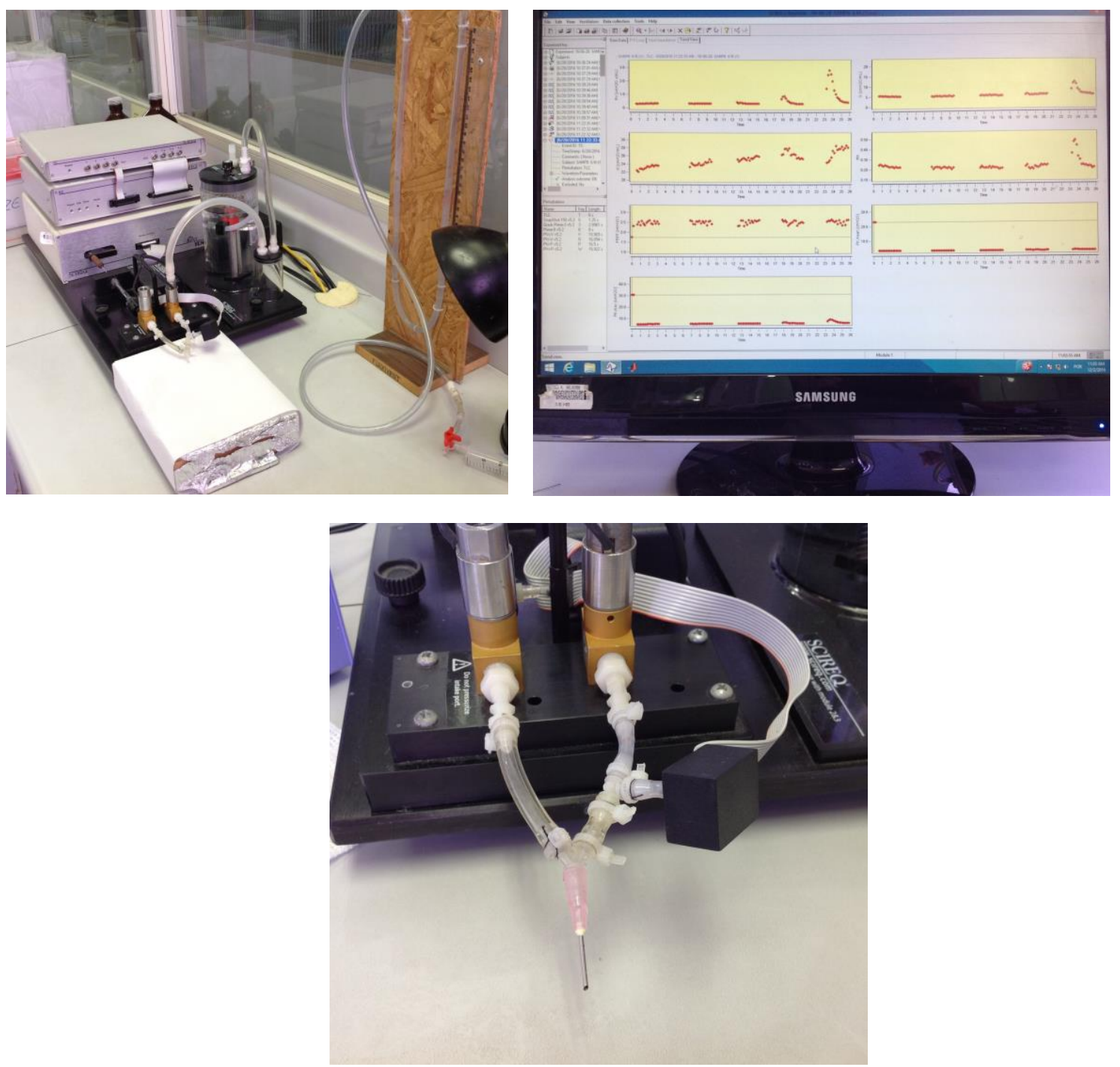

Fotografias do flexi Vent. Pode ser observado o aparelho (SCIREQ®), ao lado, imagem do sistema para captura de dados e a baixo sistema para respiração artificial. Fonte: arquivo próprio. 


\section{ANÁLISES ESTATİSTICAS}

As análises estatísticas, escolhidas de acordo com o desenho experimental, foram conduzidas utilizando GraphPad Prism 6.0 (2015). Os dados obtidos foram expressos como média \pm EPM. De forma geral, foram utilizados testes "T" de Student e Análise de Variantes (ANOVA) de uma e duas vias quando pertinentes seguidos pós-testes. Valores de $p<00,5$ foram considerados significativos. 


\section{RESULTADOS}

\subsection{Caracterização modelo de obesidade}

\subsubsection{Evolução ponderal}

A figura 4 (painéis $A$ e $B$ ) representa a evolução ponderal de camundongos ao longo de 10 semanas (painel A) e a média semanal de consumo de ração (painel B). Os camundongos foram mantidos sob dieta convencional (DC) ou dieta hiperlipídica (DH). Como pode ser observado (Painel A) camundongos mantidos com dieta convencional tiveram consumo significativamente maior de ração quando comparados aos que mantidos com dieta hiperlipídica. Este aumento mostrou-se significativo na segunda semana de $(p<0,05)$. No painel B representa a média semanal do consumo de dieta convencional e dieta hiperlipídica dos animais no período das 10 semanas. Observa se aumento do consumo da dieta convencional em relação ao consumo da dieta hiperlipídica. 
A
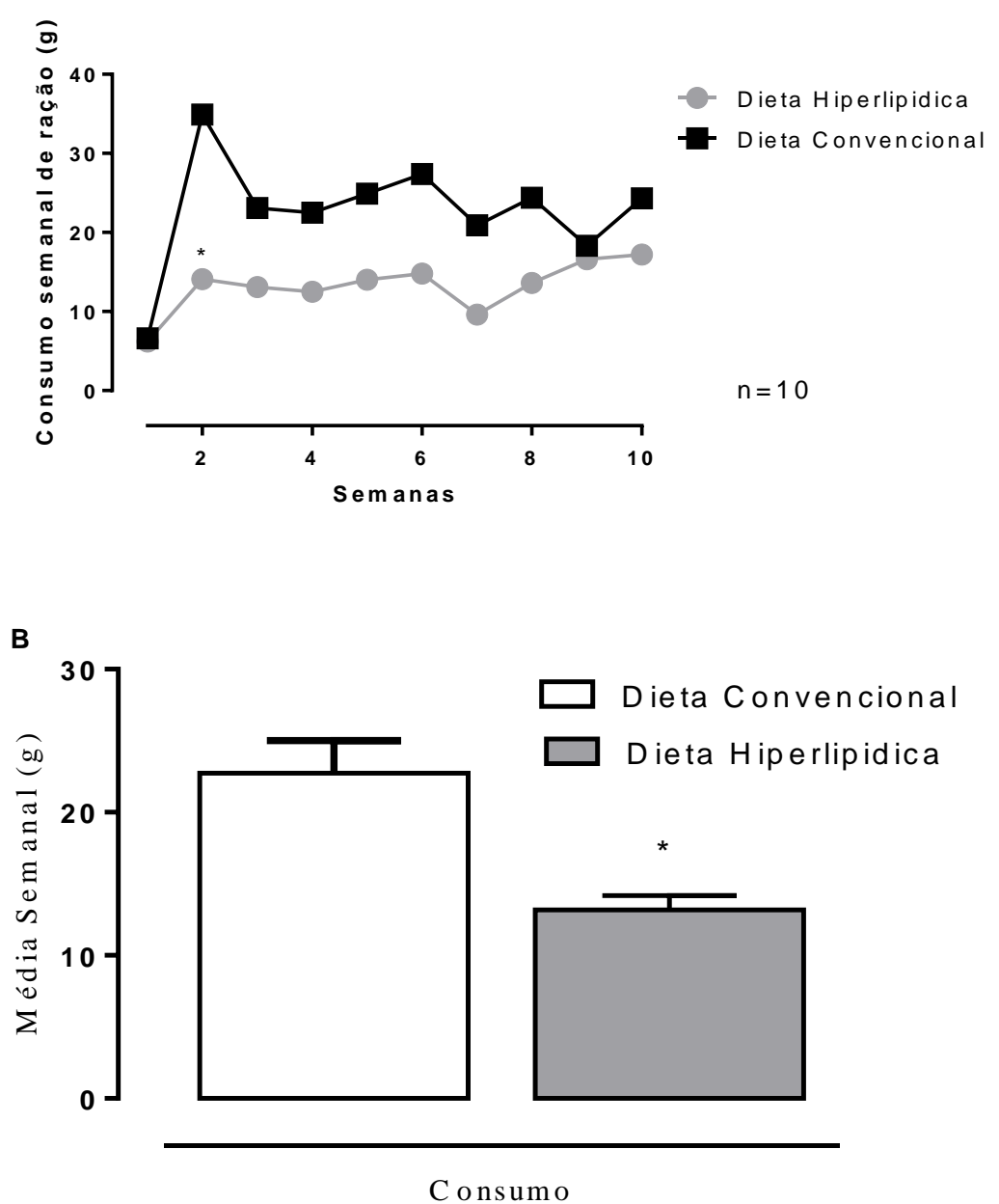

Figura 4 - Evolução ponderal de camundongos sob dieta convencional ou dieta hiperlípidica. A) Consumo semanal de ração ao longo de 10 semanas. B) Média semanal do consumo de ração entre dieta convencional e dieta hiperlípidica. Cada ponto representa média \pm epm de massa corpórea. ANOVA duas-vias: * $p<0,05 \mathrm{em}$ relação aos animais que consumiram dieta convencional, $n=10$ animais por grupo. 


\subsubsection{Ganho de Massa, tecido adiposo retroperitoneal e gonadal}

Podemos observar na figura 5, que camundongos mantidos com dieta hiperlípidica apresentaram massa corpórea maior do que os que receberam dieta convencional (painel A). Ainda, camundongos alimentados com dieta hiperlípidica apresentaram maior peso de tecido adiposo retroperitoneal (painel B) e gonadal (painel C) do que os camundongos alimentados com ração convencional.

A

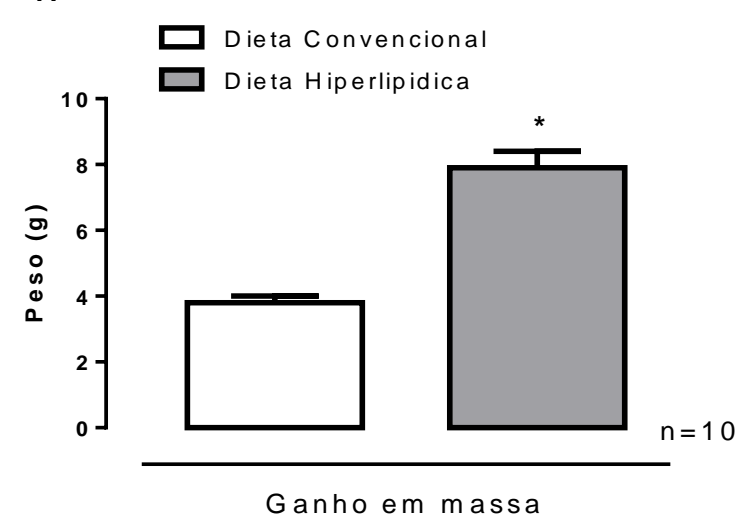

B

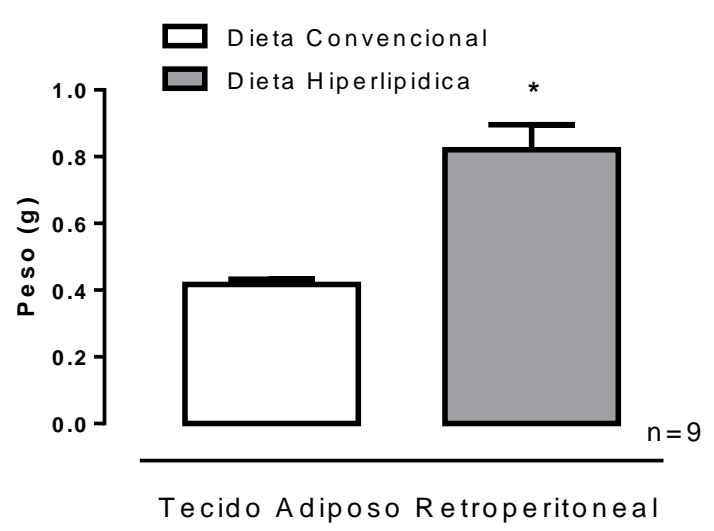


C

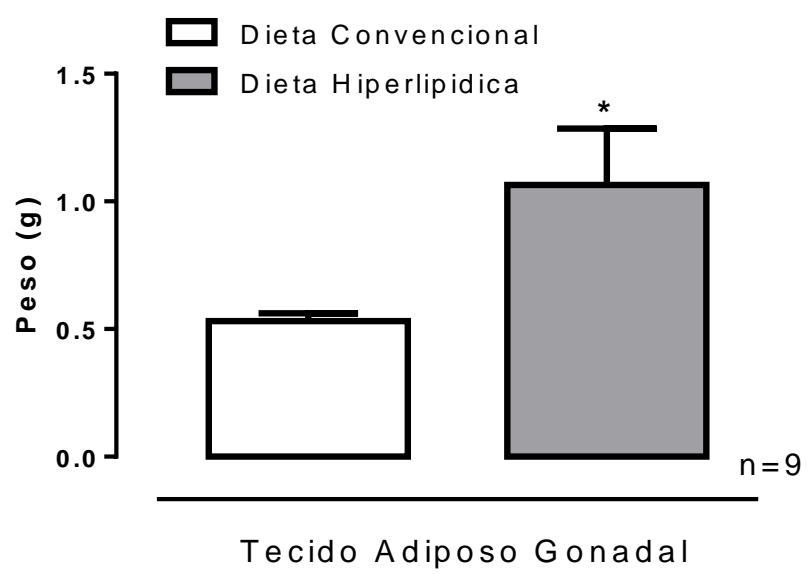

Figura 5 - Efeito da dieta hiperlípidica em camundongos fêmeas sobre a massa corporal (A), depósito de tecido adiposo retroperitoneal (B) e tecido adiposo gonadal (C). Os animais foram mantidos com dieta hiperlipídica ou convencional por 10 semanas. Os dados representam a média \pm EPM de 10 animais por grupo, ${ }^{*} p<0,05$ em relação aos animais mantidos com dieta convencional. 


\subsubsection{Concentração sérica de glicose, colesterol, HDL e triglicerídeos}

A figura 6 (painéis $A-D$ ) representam as concentrações séricas de glicose (painel A), HDL (painel B), Colesterol (painel C) e triglicerídeos (painel D) de animais sob dieta hiperlipídica (DH) ou dieta convencional (DC). Como pode ser observado, animais mantidos com a dieta hiperlipídica elevaram os índices de glicose, colesterol, HDL e triglicerídeos, em relação aos animais mantidos sob dieta convencional.
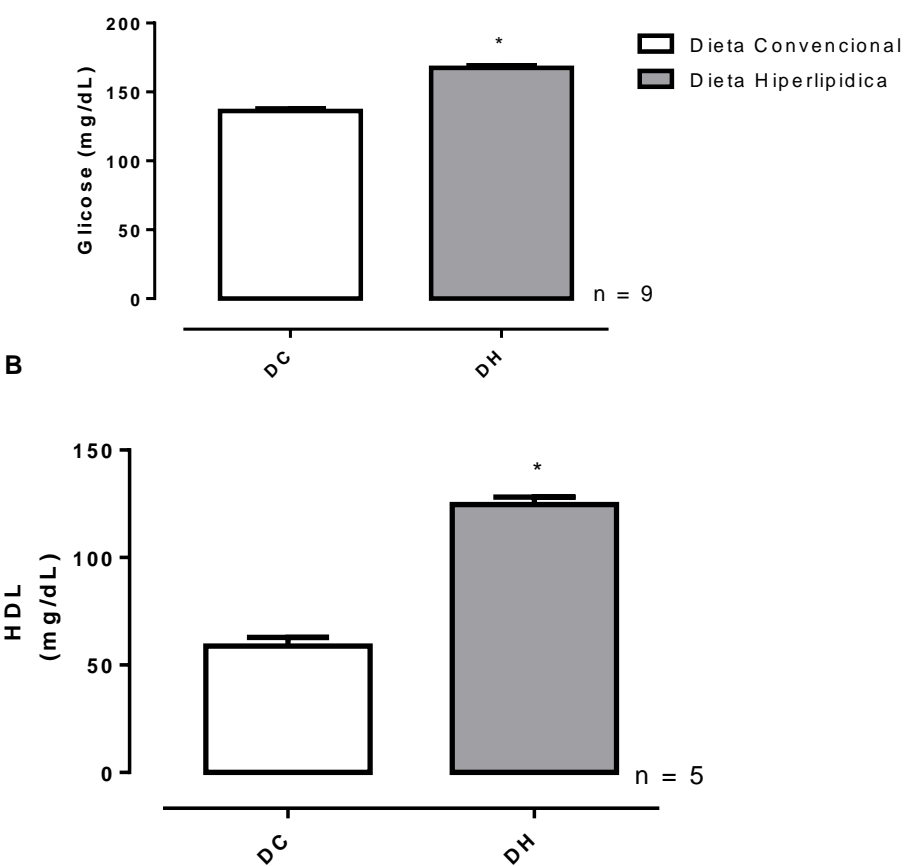

C

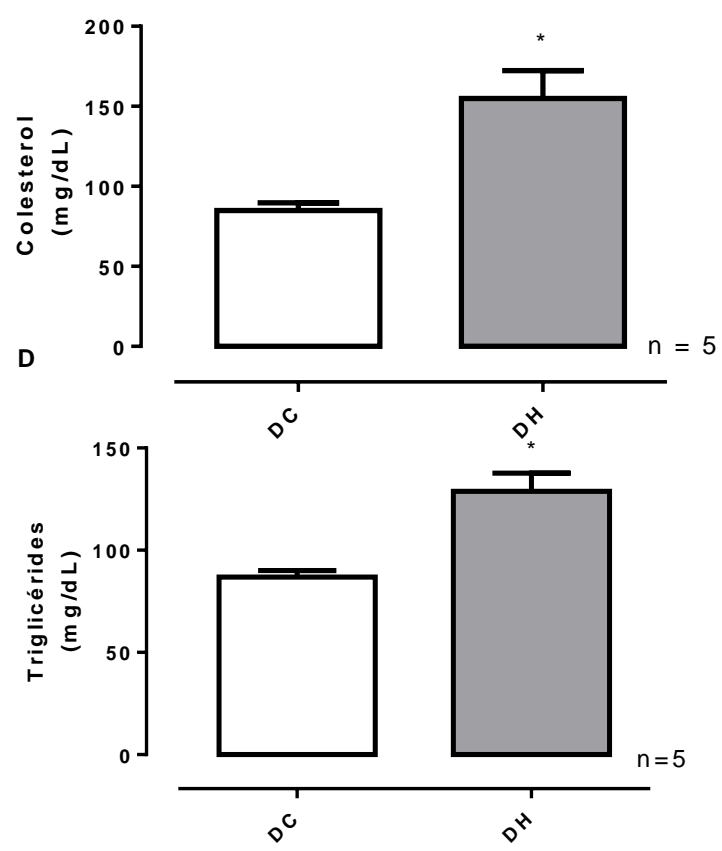

Figura 6 - Efeito do consumo de dieta hiperlipídica após 10 semanas sobre a concentração sérica de glicose (A), HDL (B), Colesterol (C) e triglicerídeos (D). Os dados representam a média EPM de 10 semanas. * $p<0,05$ em relação aos animais mantidos com dieta convencional. 


\subsection{Caracterização da asma neutrofílica experimental}

\subsubsection{Células totais do lavado bronco alveolar (LBA)}

A figura 7 representa o número total de células recuperadas do LBA de animais sensibilizados e desafiados com ovoalbumina (OVA), mantidos com dieta hiperlipídica ou convencional. Como pode ser visto animais sensibilizados e desafiados (OVA), apresentaram aumento significativo no número de células recuperadas no LBA em relação ao respectivo grupo controle. Por fim observa-se que animais do grupo controle mantidos com dieta hiperlipídica apresentaram aumento no número de células recuperada no LBA em relação ao observado no LBA de animais mantidos com dieta convencional.

LB A

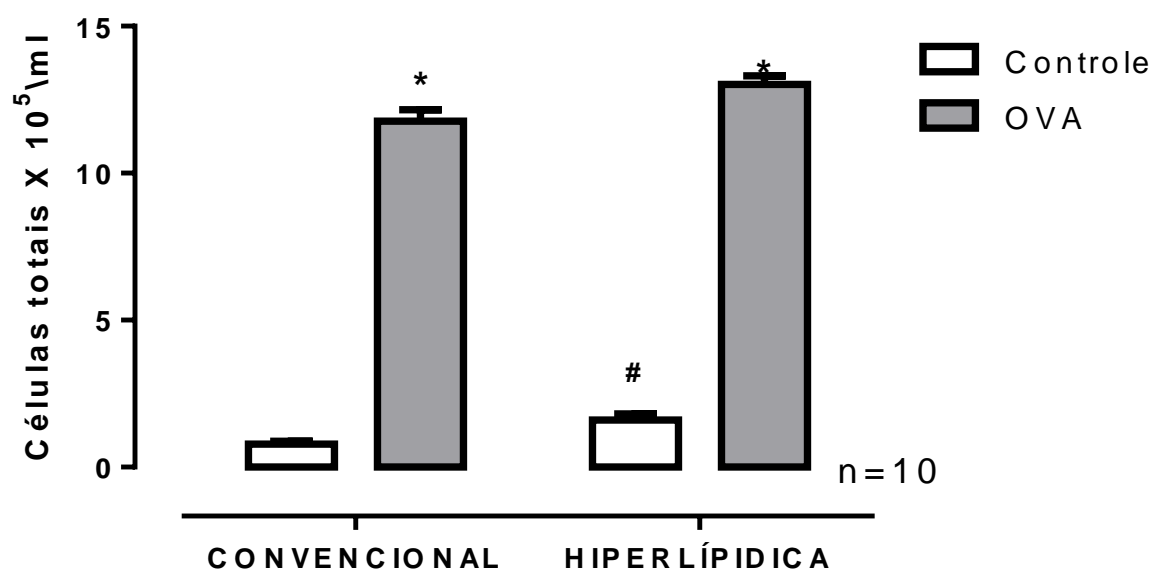

Figura 7 - Efeito do tipo de dieta sobre o número de células recuperados no lavado broncoalveolar de camundongos fêmeas sensibilizados e desafiados com ovoalbumina (OVA). Após 10 semanas de dieta hiperlipídica ou convencional os animais foram sensibilizados com OVA. Os dados representam a média \pm EPM de 10 semanas.

${ }^{*} p<0,05$ em relação aos grupos controles mantidos com dieta convencional e dieta hiperlipídica.

$\# p<0,05$ em relação ao grupo controle mantido com dieta convencional (DC). 


\subsubsection{Eosinófilos}

Em relação aos eosinófilos (figura 8), observa - se aumento significativamente maior no LBA dos animais do grupo OVA mantidos com dieta hiperlipídica em relação ao grupo OVA mantidos com dieta convencional. Não foram observadas alterações no número de eosinófilos no LBA dos animais do grupo controle, mantidos com as dietas hiperlipídica e convencional.

LB A

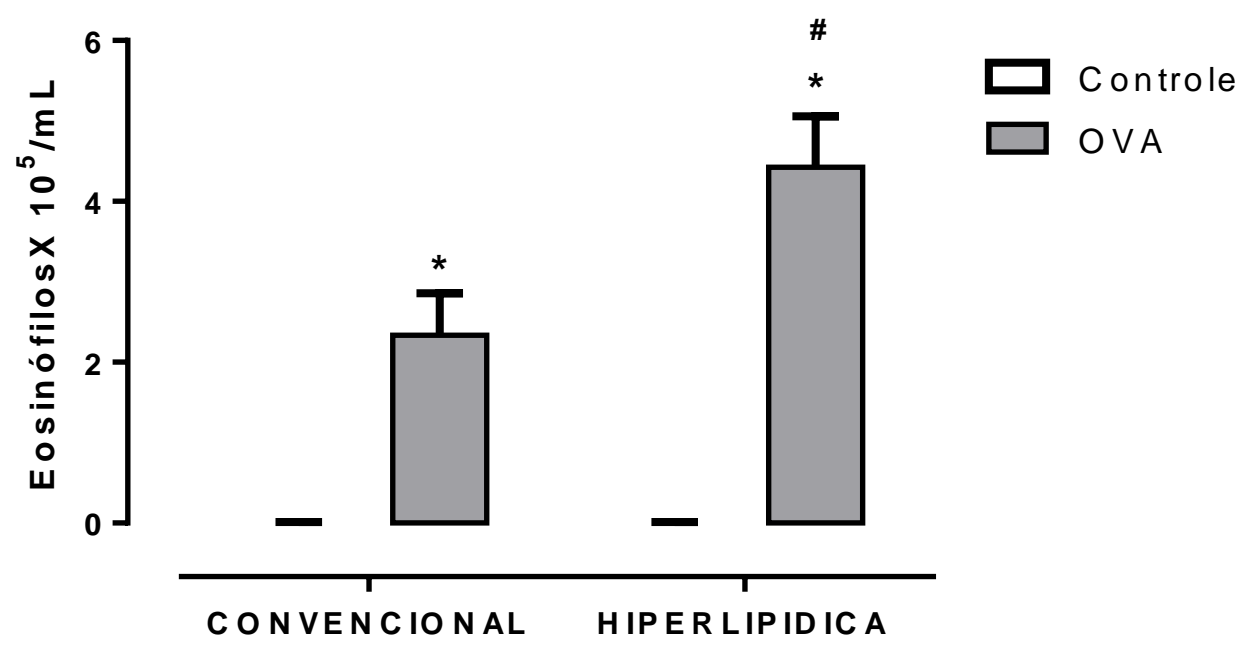

Figura 8 - Efeito do tipo de dieta sobre a quantidade de eosinófilos recuperados no lavado broncoalveolar de camundongos fêmeas sensibilizados e desafiados com ovoalbumina (OVA). Após 10 semanas de dieta com ração hiperlipídica ou convencional os animais foram sensibilizados com OVA. Os dados representam a média \pm EPM de 10 semanas e $n=10$ animais por grupo.

${ }^{*} p<0,05$ em relação aos grupos controles mantidos com dieta convencional e dieta hiperlípidica.

$\# p<0,05$ em relação ao grupo OVA mantido com dieta convencional. 


\subsubsection{Neutrófilos}

A figura 9, representa a quantidade de neutrófilos quantificados no LBA de animais do grupo controle e sensibilizados e desafiados com OVA mantidos com dieta convencional ou hiperlipídica. Como pode ser visto, o desafio com OVA elevou significativamente o número de neutrófilos no LBA, de animais mantidos com dietas hiperlipídica ou convencional, em relação ao seu respectivo grupo controle.

LB A

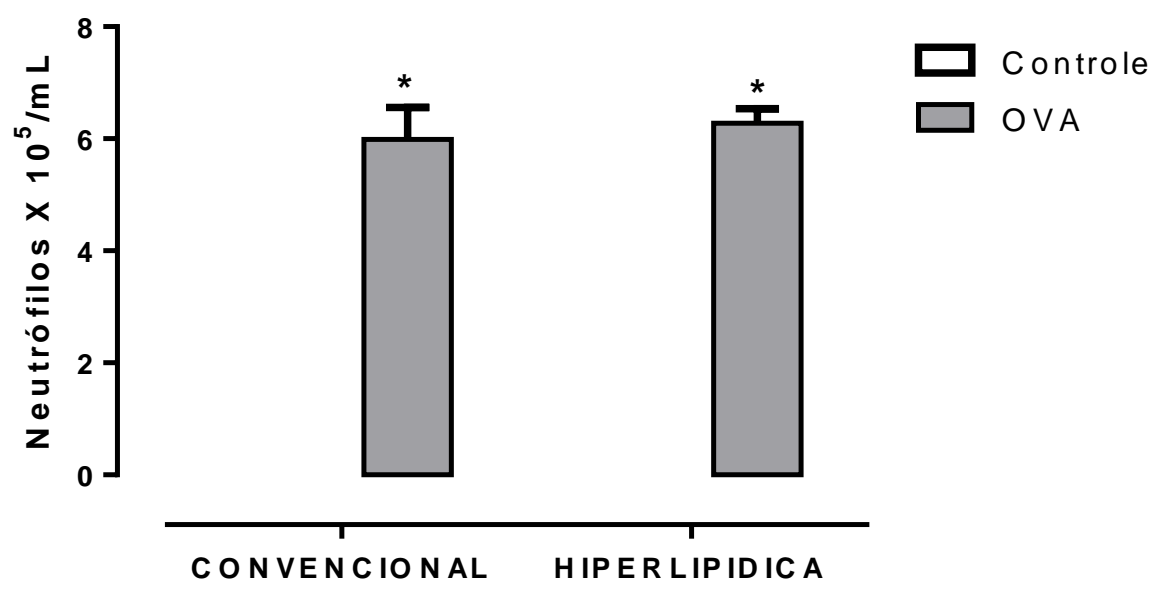

Figura 9 - Efeito do tipo de dieta sobre a quantidade de células neutrofílica no lavado broncoalveolar de camundongos fêmeas sensibilizados e desafiados com ovoalbumina (OVA). Os dados representam a média \pm EPM de 10 semanas.

* $p<0,05$ em relação aos grupos controles mantidos com dieta convencional e dieta hiperlipídica. 


\subsubsection{Mononucleares}

Por fim, a figura 10 representa o número de células mononucleares, recuperadas do LBA, onde observa - se aumento de forma significativa dos animais do grupo controle sob dieta hiperlipídica em relação aos seus respectivos grupos mantidos com dieta convencional. Além do mais, foram observadas reduções significativas entre os animais do grupo OVA mantidos com dieta hiperlipídica comparada com animais mantidos com dieta convencional não sensibilizados.

LB A

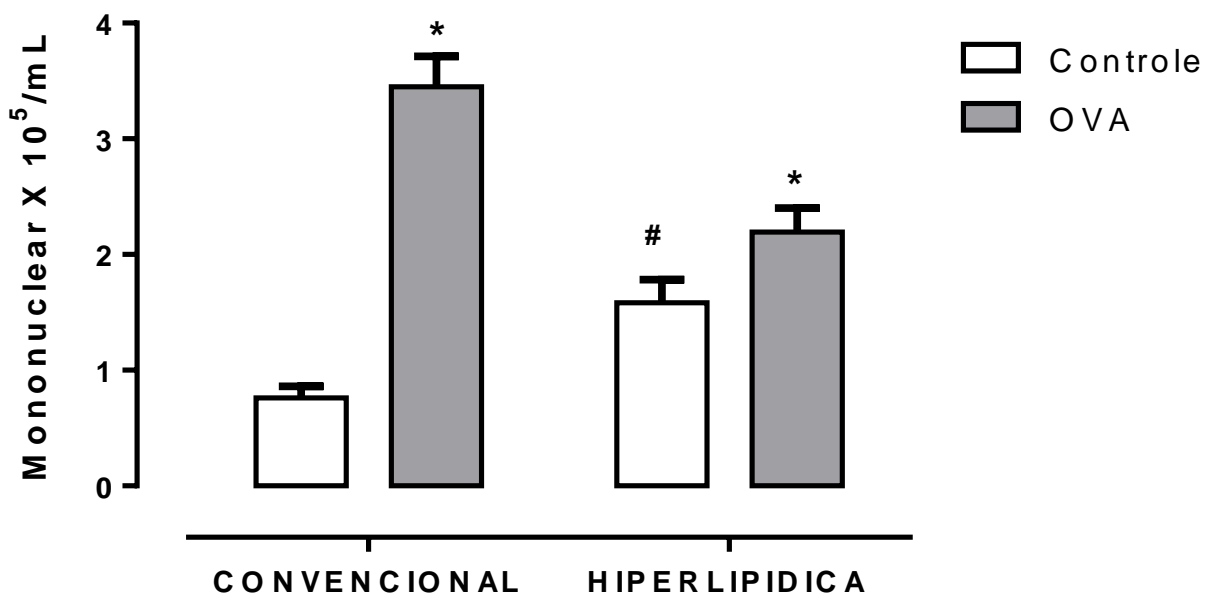

Figura 10 - Efeito do tipo de dieta sobre a porcentagem de mononucleares recuperados no lavado broncoalveolar de camundongos fêmeas sensibilizados e desafiados com ovoalbumina (OVA). Após 10 semanas de dieta com ração hiperlipídica ou convencional os animais foram sensibilizados com OVA. Os dados representam a média \pm EPM de 10 semanas. * $p<0,05$ em relação aos grupos controles mantidos com dieta convencional e dieta hiperlípidica.

\# $p<0,05$ em relação aos grupos controle mantidos com dieta convencional. 


\subsubsection{Atividade das enzimas eosinoperoxidase (EPO) e mieloperoxidase (MPO) no pulmão}

A figura 11 (painéis $A$ e $B$ ) representam as atividades das enzimas eosinoperoxidase (EPO) e mieloperoxidase (MPO) respectivamente, no pulmão dos animais mantidos com as dietas hiperlipídica e convencional e posteriormente sensibilizados e desafiados com OVA. Como pode ser visto no painel $A$ houve significativo aumento de EPO no pulmão dos animais dos grupos sensibilizados e desafiados com OVA, em relação aos seus respectivos controles. No grupo controle onde, os animais foram mantidos com dieta hiperlípidica não houve aumento de EPO comparado ao dos animais mantidos com dieta convencional. No painel B observamos que houve aumento significativo da enzima MPO no pulmão dos grupos sensibilizados e desafiados com OVA comparado aos respectivos grupos controle. Ainda notamos aumento da atividade de MPO no pulmão dos animais do grupo controle mantidos com dieta hiperlipídica comparado com o dos animais do grupo controle mantidos com dieta convencional.

A

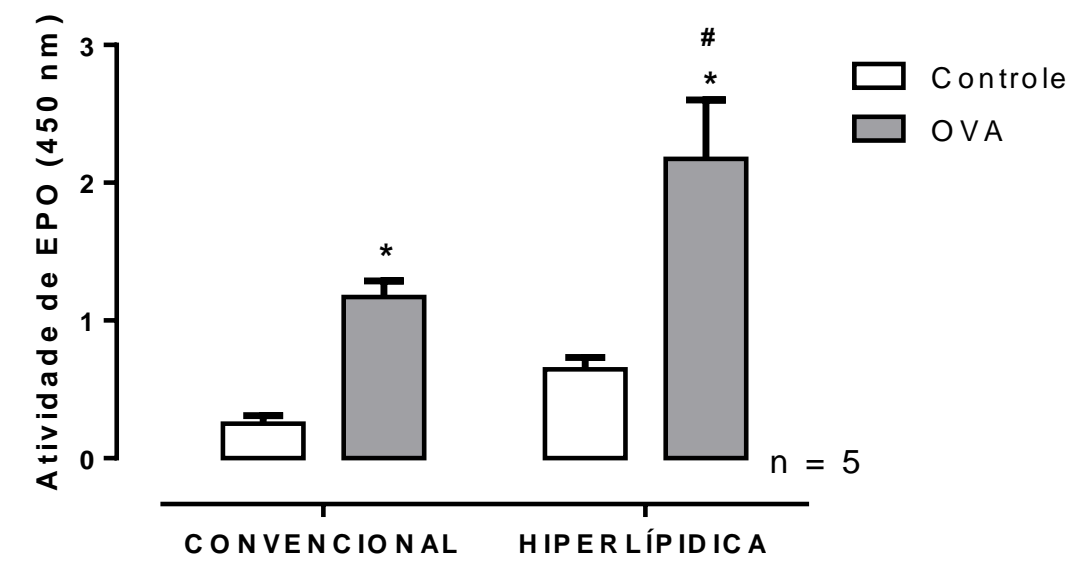




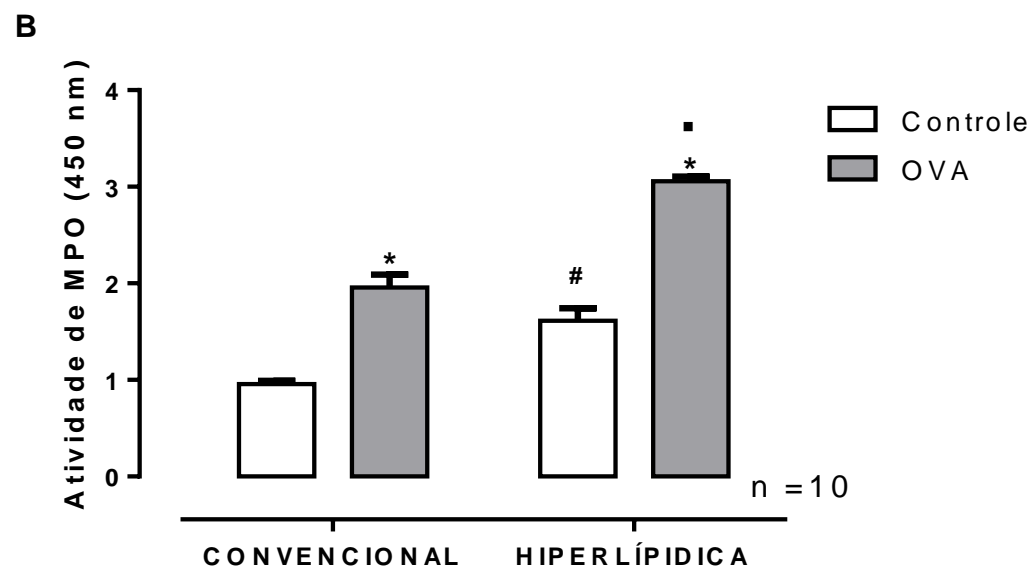

Figura 11 - Efeito do tipo de dieta sobre a atividade das enzimas eosinoperoxidase (EPO) e mieloperoxidase (MPO) em pulmão de camundongos fêmeas sensibilizados e desafiados com ovoalbumina (OVA). Após 10 semanas de dieta hiperlipídica ou convencional os animais foram sensibilizados com OVA. Os dados representam a média \pm EPM de 10 semanas. * $p<0,05$ em relação aos grupos controles mantidos com dieta convencional e dieta hiperlipídica. \# $p<0,05$ em relação aos grupos controle mantido com dieta convencional. - $p<0,05$ em relação aos grupos OVA mantidos com dieta convencional. 


\subsubsection{Concentração das Imunoglobulinas (IgG) e (IgE) no lavado broncoalveolar e no soro}

A figura 12 (painéis $A$ e $B$ ) representa as atividades das imunoglobulinas $G$ e e respectivamente no lavado broncoalveolar dos animais controle e dos animais sensibilizados e desafiados com OVA. Os painéis (C e D) representam as mesmas imunoglobulinas, porém no soro. Como pode ser visto nos painéis ( $A$ e $B$ ) houve aumento significativo da $\lg$ e $\lg E$ no LBA dos animais sensibilizados e desafiados com OVA, em relação ao grupo controle.

Com respeito aos valores obtidos no soro, nossos dados mostraram que houve aumento significativo da concentração das imunoglobulinas $G$ no soro dos animais sensibilizados e desafiados com OVA comparada com a do grupos controle (painel C). No entanto no painel D observamos que não houve aumento significativo da concentração de lgE entre os grupos.

A

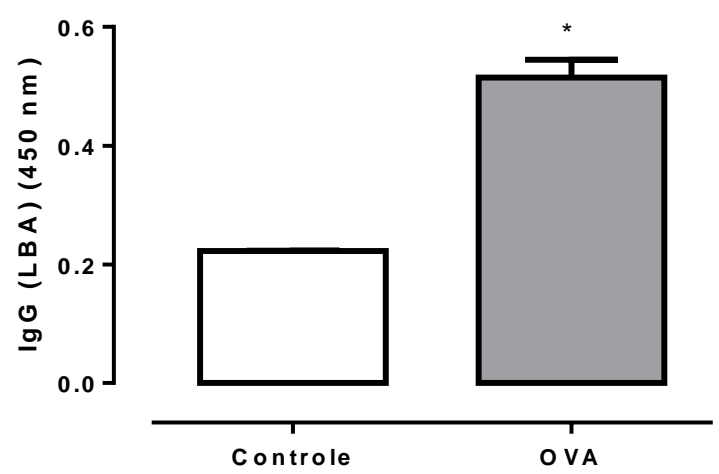

B

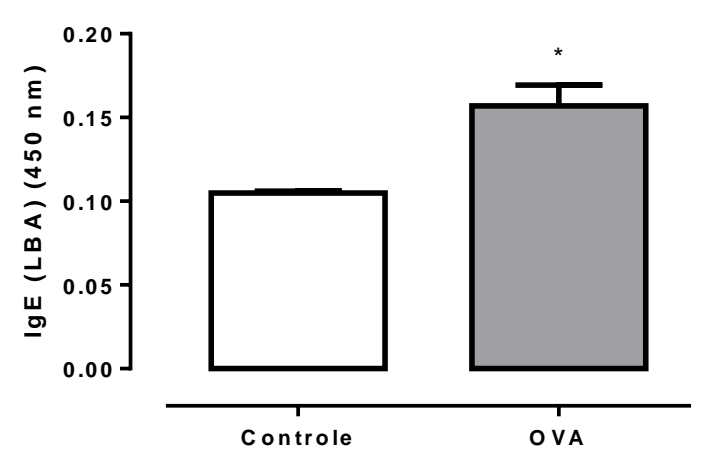


C

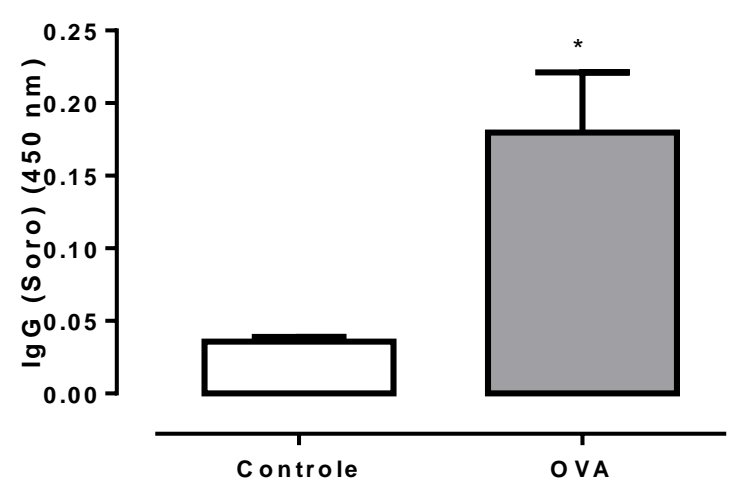

D

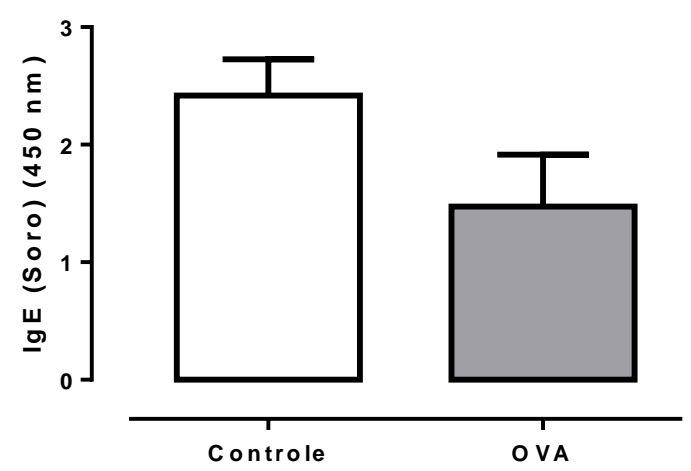

Figura 12 - Concentração das imunoglobulinas $\mathrm{G}$ e E, em pulmão de camundongos fêmeas, falsamente sensibilizadas e desafiadas com PBS (grupo controle) e sensibilizados e desafiados com ovoalbumina (grupo OVA). Os dados representam a média \pm EPM de 10 semanas. * $p<0,05$ em relação aos grupos controles. 


\subsubsection{Perfil de células recuperadas no lavado broncoalveolar de animais com Inflamação neutrofílica e eosinofílica}

A figura 13 apresenta o número de eosinófilos, neutrófilos e mononucleares recuperados no LBA de animais sob dieta convencional com asma neutrofílica ou eosinofílica. Como pode ser observado, animais com asma neutrofílica, apresentaram aumento significativo no número de neutrófilos em relação ao número de eosinófilos. No entanto, animais com asma eosinofílica apresentam número maior de eosinófilos em comparação ao número de neutrófilos.

Inflam ação neutrofílica

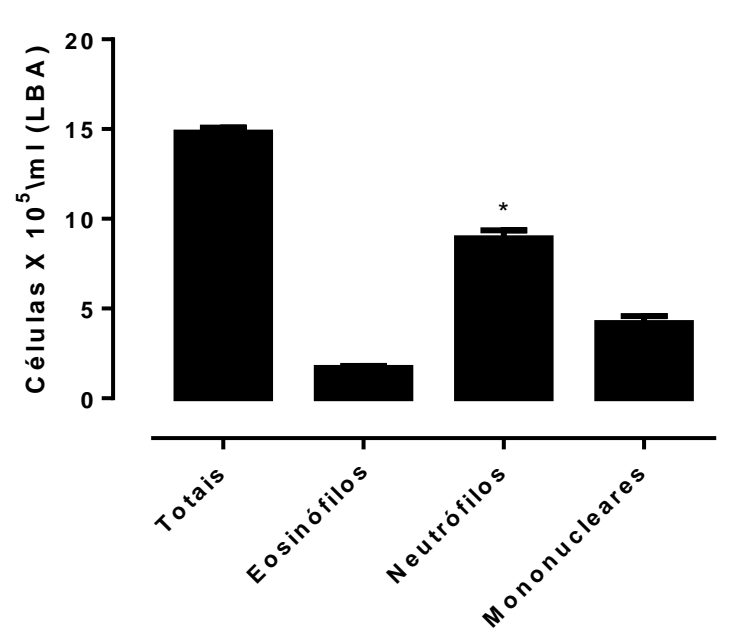

In flam ação e o sin ofílica

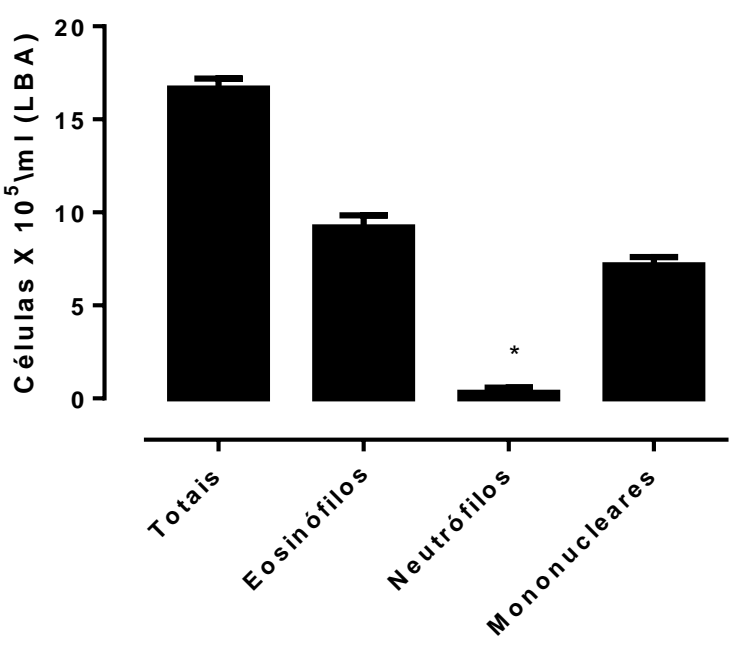

Figura 13 - Diferença entre o número de eosinófilos e neutrófilos recuperados no lavado broncoalveolar de camundongos fêmeas sensibilizados e desafiados com ovoalbumina (OVA) com inflamação neutrofílica e eosinofílica. Os dados representam a média \pm EPM de 10 animais. ${ }^{*} p<0,05$ em relação à quantidade de eosinófilos e neutrófilos. 


\subsubsection{Avaliação da mecânica pulmonar de animais com asma neutrofílica ou eosinofílica tratados com budesonida}

Nestes estudos, investigamos o efeito da budesonida na asma neutrofílica e eosinofílica desencadeada em animais mantidos sob dieta convencional. De forma a investigar a resistência das vias aéreas ( $\mathrm{Rn}$ painel $A)$, resistência do parênquima pulmonar ( $G$ painel $B$ ) e elastância do parênquima pulmonar (H painel $C$ ). Nossos dados indicaram redução significativas de ( $R n$ painel $A)$, ( $G$ painel $B)$ e $(H$ painel $C)$ dos animais com asma eosinofílica (OVA EOS + BUD), em relação ao grupo não tratado (OVA EOS). No entanto em, animais com asma neutrofílica tratados com budesonida (OVA NEUT + BUD) não foi observado redução significativa de (Rn painel $A)$, (G painel B) e (H painel $C$ ) em relação ao grupo não tratado (OVA NEUT).

A

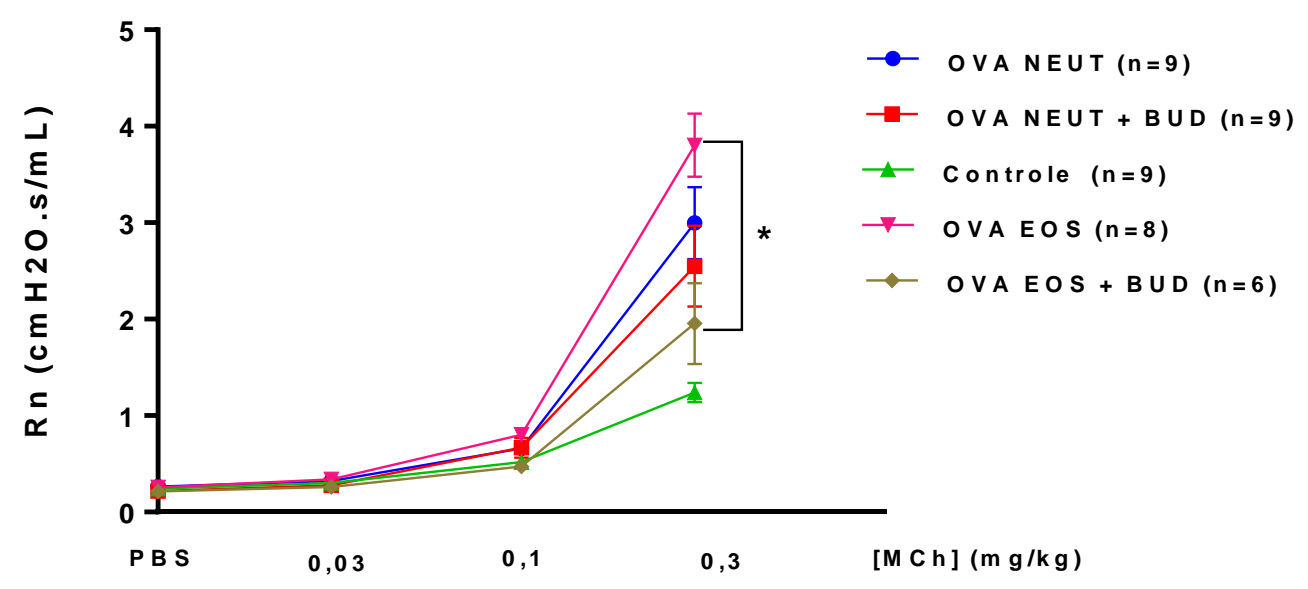


B
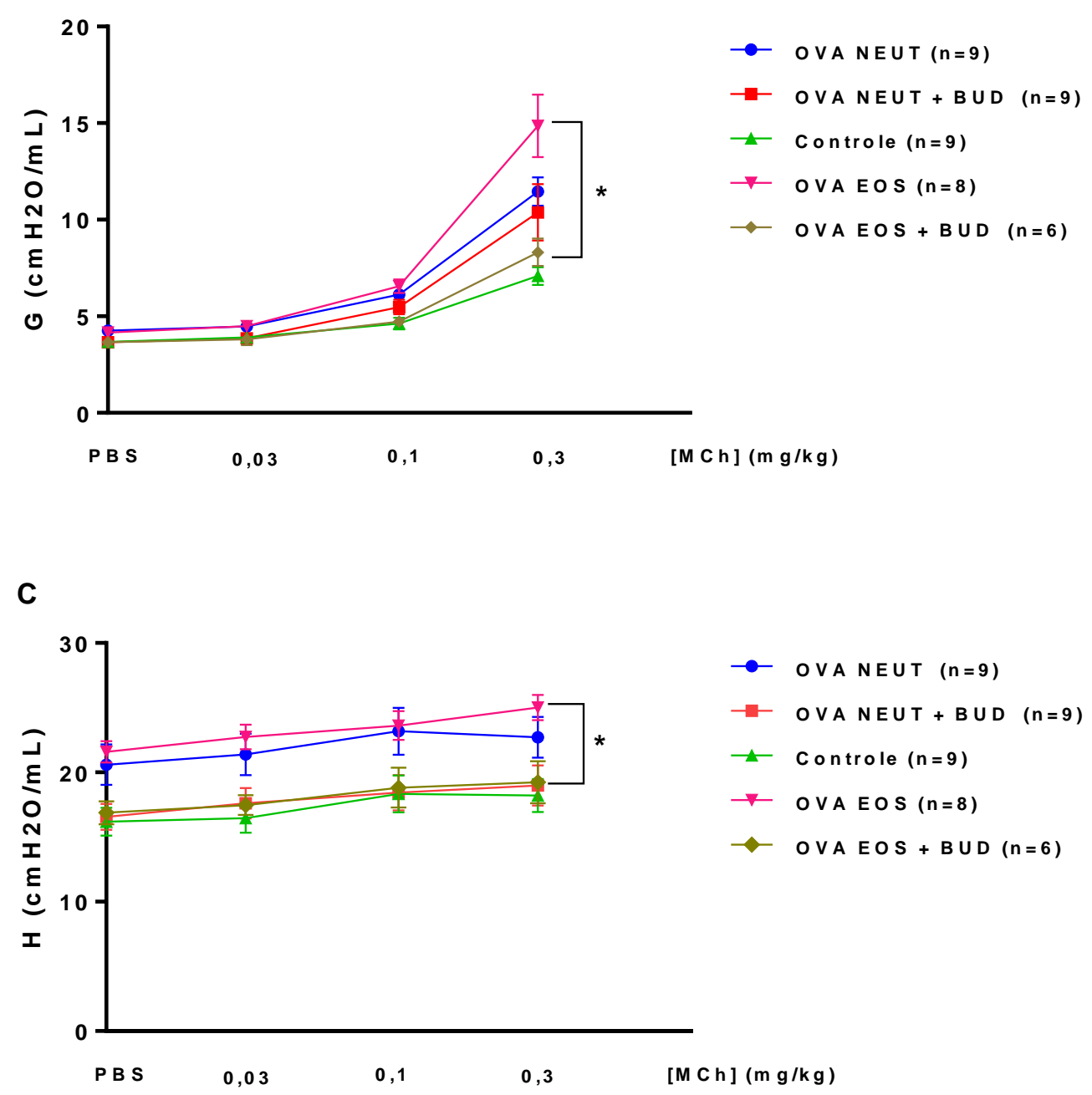

Figura 14 - Avaliação da mecânica pulmonar de animais com asma neutrofílica e eosinofílica tratados com budesonida. Os dados representam a média \pm EPM de $6-$ 9 animais. Os dados foram analisados pela ANOVA de duas vias, seguido de teste de Bonferroni. * $p<0,05$ em relação ao grupo OVA EOS não tratado. 


\subsubsection{Efeitos do tratamento dos animais com budesonida sobre os números de células recuperadas do lavado broncoalveolar}

A figura 15 representa o número total de células recuperadas do LBA de animais sensibilizados e desafiados com ovoalbumina (OVA), com asma neutrofílica ou eosinofílica tratados com budesonida (BUD) e mantidos com dieta convencional. Como pode ser visto, animais sensibilizados e desafiados com inflamação eosinofílica, apresentaram aumento significativo no número de células recuperadas no LBA em relação ao respectivo grupo de animais com inflamação neutrofílica. Por outro lado, observa-se que animais com inflamação eosinofílica tratados com BUD apresentaram diminuição no número de células recuperada no LBA em relação aos animais com inflamação neutrofílica. Além disso, animais com inflamação neutrofílica que receberam o tratamento farmacológico com BUD não apresentaram alterações significativas no número de células recuperadas no LBA em relação ao grupo não tratado.

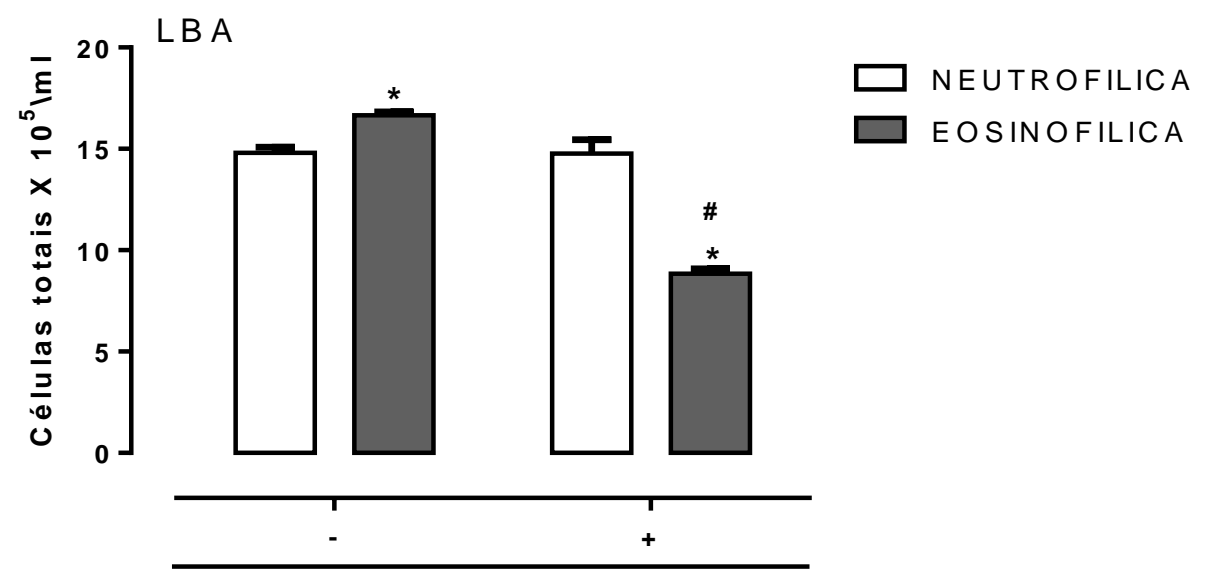

BUDESONIDA

Figura 15 - Efeito do tratamento com budesonida (BUD) sobre o número de células recuperados no lavado broncoalveolar de camundongos fêmeas sensibilizados e desafiados com ovoalbumina (OVA) com inflamação neutrofílica e eosinofílica. Os dados representam a média \pm EPM de 10 animais. ${ }^{*} p<0,05$ em relação aos grupos de animais com inflamação neutrofílica. \# $p<0,05$ em relação ao grupo de animais com inflamação eosinofílica. 


\subsubsection{Efeitos do tratamento dos animais com budesonida sobre os números de células diferenciais recuperadas do lavado broncoalveolar}

A figura 16 representa o número de células diferenciais (painéis $A-C$ ) recuperadas do LBA de animais sensibilizados e desafiados com OVA, com asma neutrofílica (OVA NEUT) ou eosinofílica (OVA EOS) tratados com budesonida (BUD) e mantidos com dieta convencional. Como pode ser observado, animais sensibilizados e desafiados com (OVA NEUT) e (OVA EOS) tratados com (BUD) apresentaram redução no número de eosinófilos recuperadas no LBA, em relação aos respectivos grupos não tratados (painel $A$ ). Por outro lado, observa-se que animais com asma eosinofílica (OVA EOS) tratados com (BUD) apresentaram redução no número de eosinófilos recuperada no LBA em relação aos animais do grupo não tratado, no entanto animais com asma neutrofílica (OVA NEUT) tratados com (BUD) não apresentaram alteração significativa dos eosinófilos em relação aos animais com (OVA NEUT) não tratados (painel B). O mesmo foi observado com o número de mononucleares recuperados no LBA de animais com (OVA EOS) tratados com (BUD) estes apresentaram redução significativa de mononucleares em comparação com animais com (OVA EOS) não tratados, e não se observou alterações nos animais com (OVA NEUT) tratados (BUD) em relação aos animais com asma neutrofilica não tratados (painel C). 
A

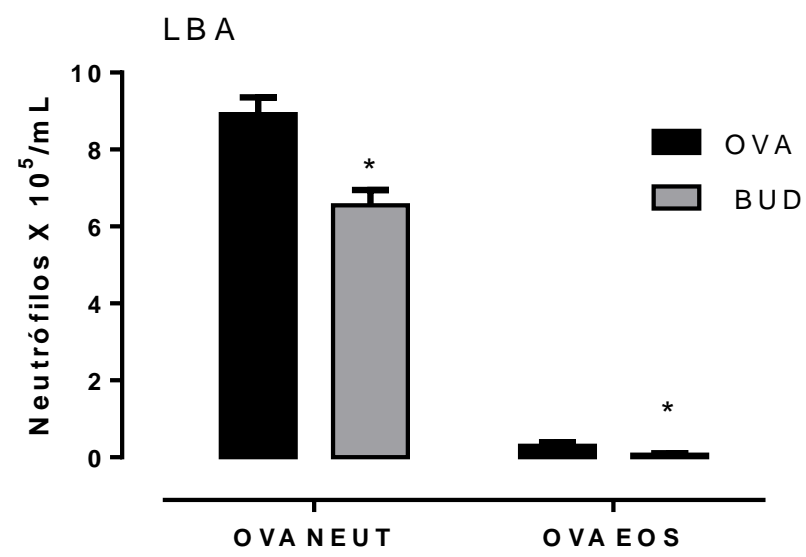

B LB A

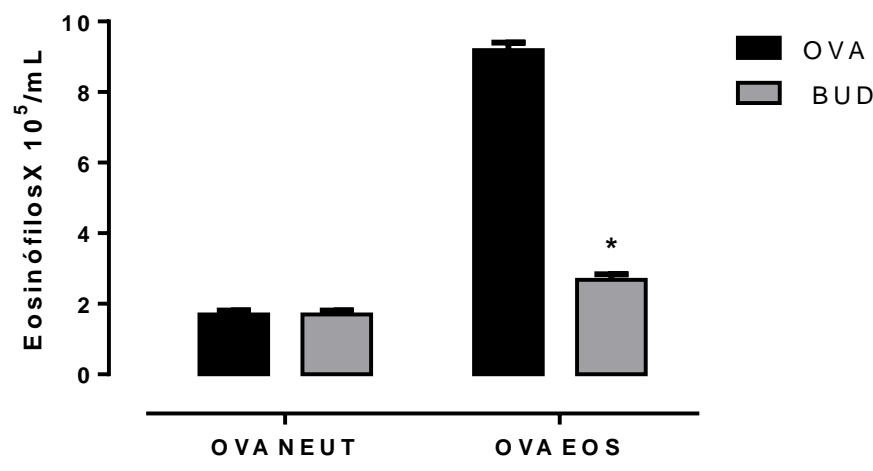

C

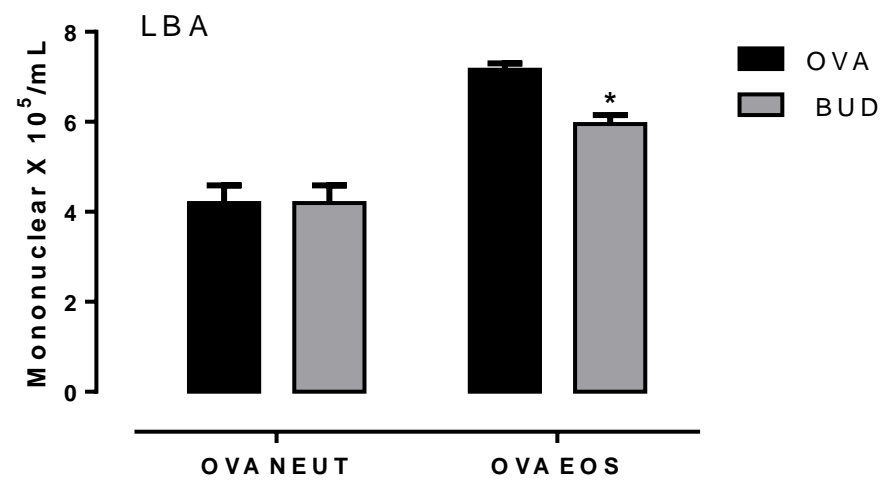

Figura 16 - Efeito do tratamento com budesonida (BUD) sobre o número de células diferenciais recuperados no lavado broncoalveolar de camundongos fêmeas sensibilizados e desafiados com ovoalbumina (OVA) com asma neutrofílica e 
eosinofílica. Os dados representam a média \pm EPM de 10 animais. * $p<0,05$ em relação aos grupos de animais com asma neutrofílica e asma eosinofílica não tratados. 


\subsection{Asma e Obesidade}

\subsubsection{Avaliação da mecânica pulmonar (MCh via i.v.)}

Nestes estudos, investigamos a resistência das vias aéreas (Rn painel $A$ ), resistência do parênquima pulmonar ( $G$ painel $B$ ) e elastância do parênquima pulmonar ( $\mathrm{H}$ painel $\mathrm{C}$ ) dos animais. Nossos dados não revelaram diferenças significativas entre animais mantidos com dieta hiperlipídica (DH) sensibilizados e desafiados com OVA (asma neutrofilica) em relação aos animais sensibilizados e desafiados com OVA que consumiram dieta convencional (DC). Ainda, não detectamos diferenças entre animais do grupo controle que receberam dieta hiperlipídica(DH) quando comparados aos animais do grupo controle que receberam dieta convencional (DC).

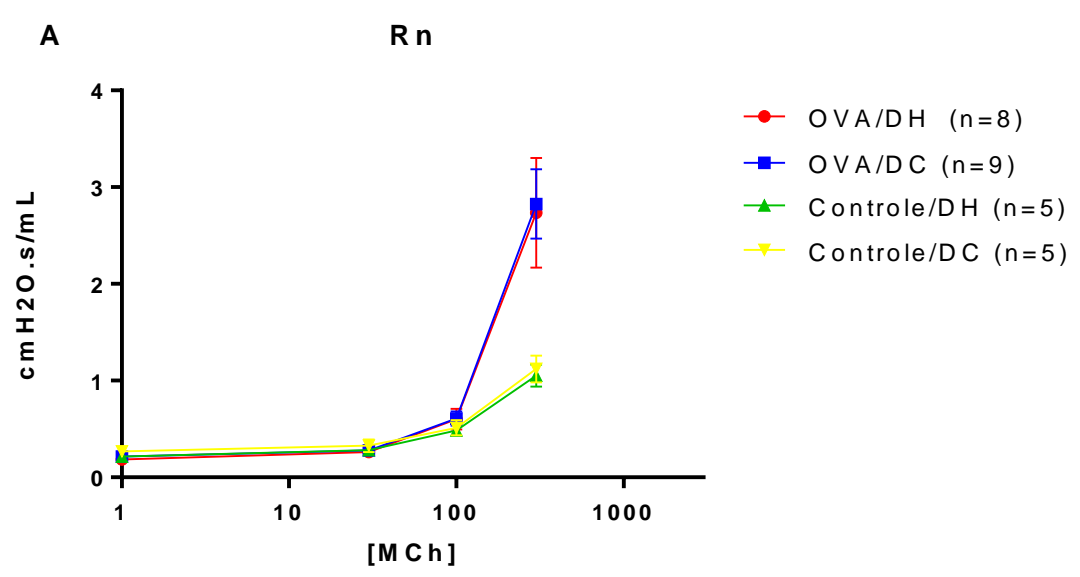

B

G

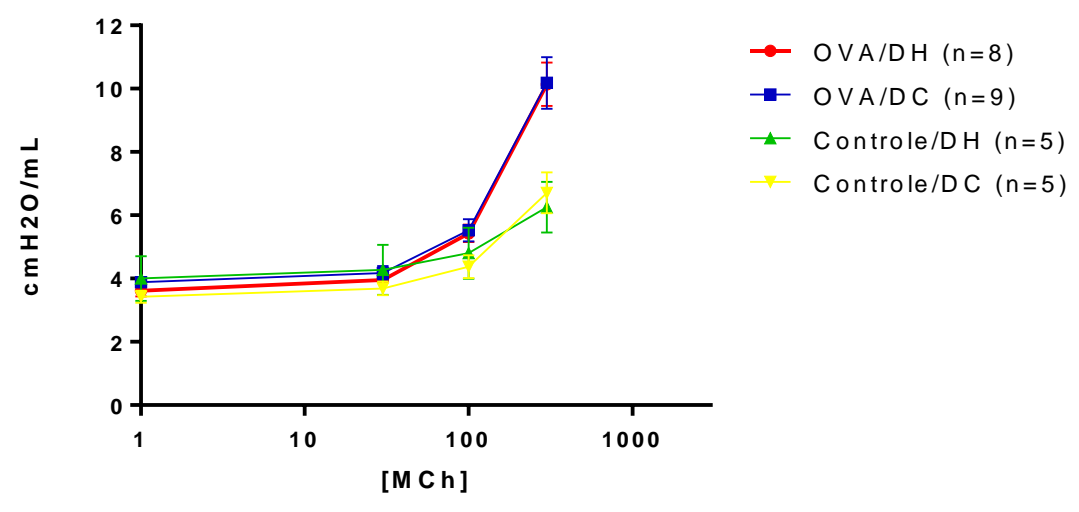


c

H

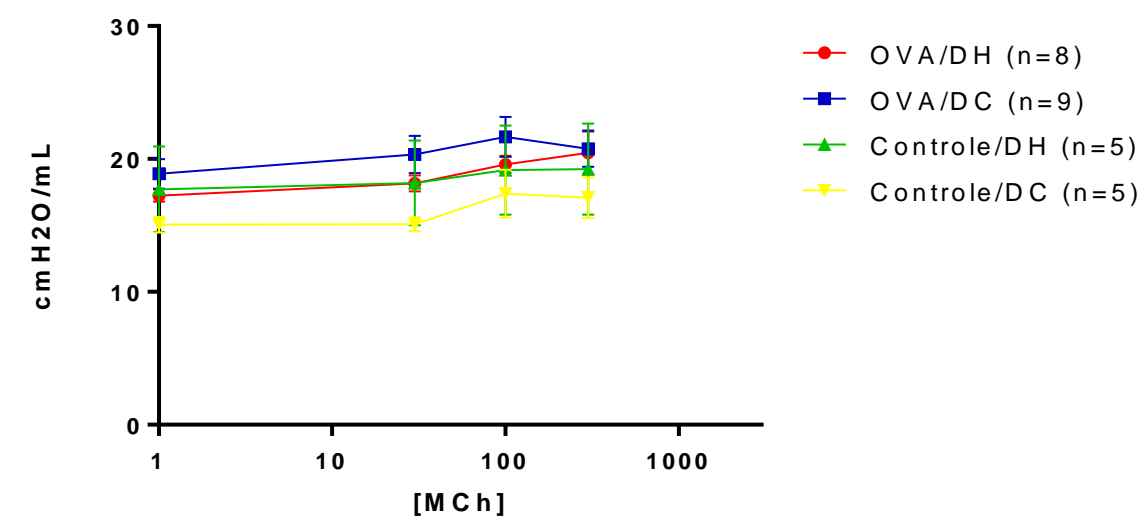

Figura 17 - Grupos experimentais decorrido 1 dia após o último desafio. )Os animais foram submetidos à avaliação da mecânica pulmonar no flexi Venti à MCh via i.v. Os painéis demonstram a resposta máxima de $\mathrm{Rn}, \mathrm{G}$ e $\mathrm{H}$. Os dados representam a média \pm EPM de $5-9$ animais. Os dados foram analisados pela ANOVA de duas vias seguido de teste de Bonferroni. 


\subsubsection{Avaliação de citocinas no lavado broncoalveolar}

A figura 18 revelou aumento na liberação de TNFa, no lavado broncoalveolar de animais sensibilizados e desafiados com OVA mantidos com dieta convencional ou dieta hiperlípidica em relação aos animais do grupo controle em ambas as dietas. Também observamos um aumento significativo da liberação de TNFa no LBA dos animais sensibilizados e desafiados com OVA mantidos sob dieta hiperlípidica em relação aos animais sensibilizados e desafiados com OVA mantidos sob dieta convencional. O mesmo ocorreu entre os animais do grupo controle mantido com dieta hiperlipídica em relação aos animais do grupo controle mantidos com dieta convencional.

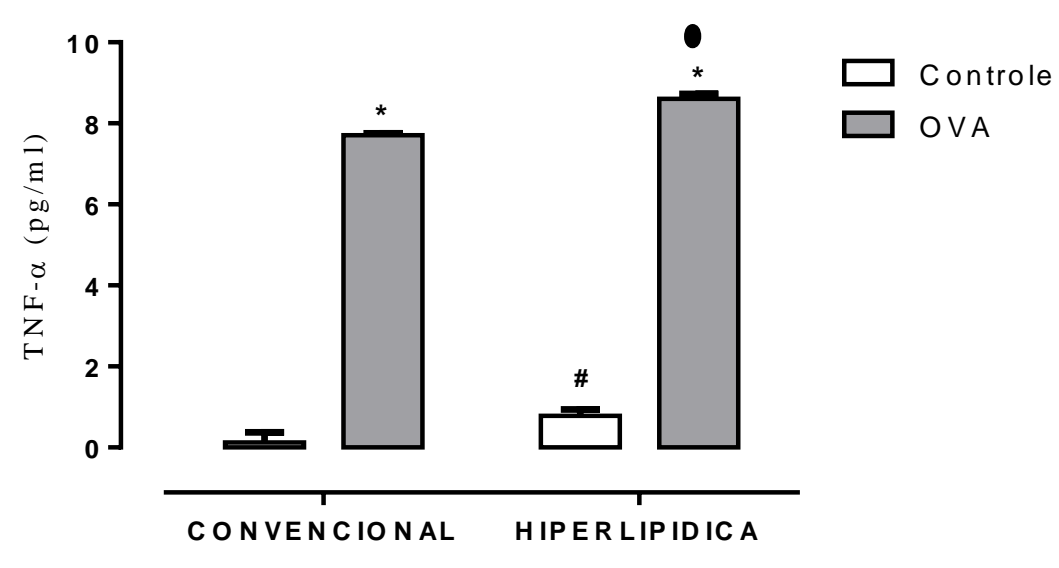

Figura 18 - Os grupos experimentais consistiram em animais mantidos com dieta controle e animais mantidos com dieta hiperlípidica por 10 semanas, também utilizamos animais controle e animais sensibilizados e desafiados com OVA. Posteriormente, após o último desafio, os animais foram submetidos a eutanásia e recolhido o lavado bronco alveolar para análise. Os dados representam a média \pm EPM de 10 animais. * $p<0,05$ em relação aos animais do grupo controle mantidos com ambas dietas. \# $p<0,05$ em relação aos animais que consumiram ração convencional do grupo controle. $\Theta p<0,05$ em relação ao animais sensibilizados e desafiados com OVA mantidos com dieta convencional. 
Os dados referentes à IL1- $\beta$ estão representados na figura 19. Podemos observar que os animais do grupo sensibilizados e desafiados com OVA tiveram aumento da liberação de IL1- $\beta$, quando comparados com os dados obtidos em LBA de animais do grupo controle de ambas as dietas. Ainda observamos aumento na liberação de IL1- $\beta$ entre os animais sensibilizados e desafiados com OVA mantidos com dieta hiperlipídica em relação aos animais do mesmo grupo mantidos com dieta convencional. No entanto, não observamos diferenças no grupo controle de animais mantidos com dieta hiperlipídica em relação ao grupo de animais controle mantidos com dieta convencional.

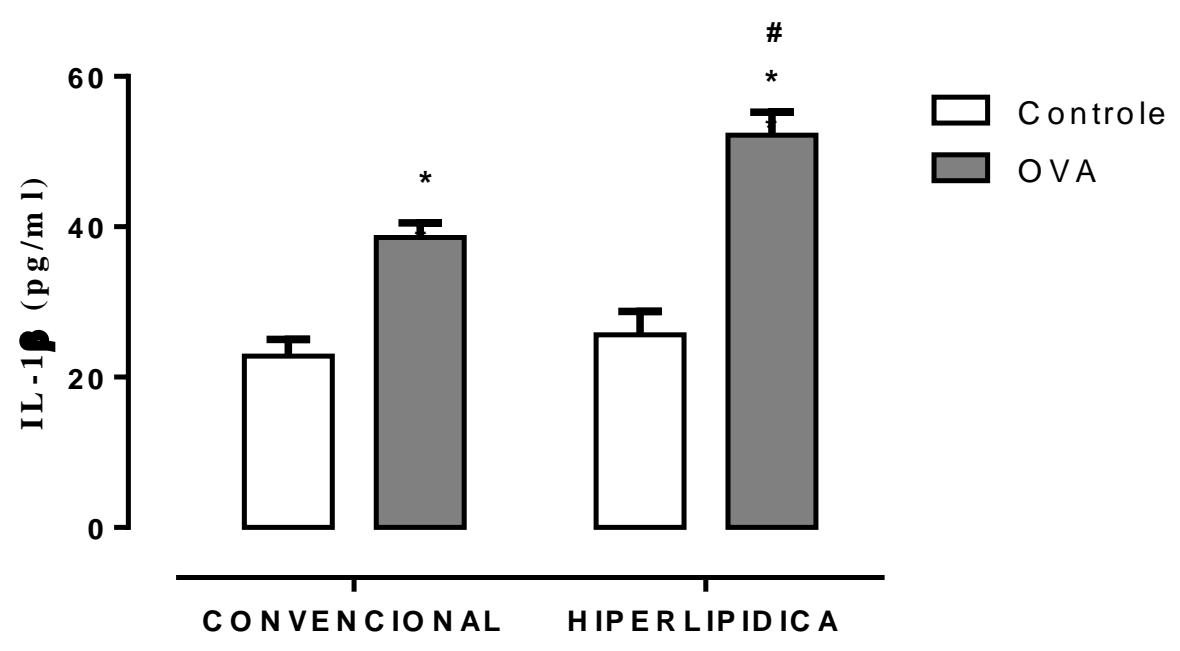

Figura 19 - Os grupos experimentais consistiram em animais mantidos com dieta convencional e animais mantidos com dieta hiperlípidica por 10 semanas, também utilizamos animais controle e animais sensibilizados e desafiados com OVA. Posteriormente, após o último desafio, os animais foram submetidos a eutanásia e recolhido o lavado bronco alveolar para análise. Os dados representam a média \pm EPM de 10 animais. * $p<0,05$ em relação aos grupos de animais controle mantidos em ambas dietas. \# $p<0,05$ em relação aos animais sensibilizados e desafiados com OVA mantidos com dieta convencional. 
A figura 20 representa a concentração de INF presente em amostras de lavado bronco alveolar obtidas dos grupos investigados. Como podemos observar, o LBA do grupo de animais sensibilizados e desafiados com OVA aumentou a liberação de INF, quando comparado com o LBA de animais do grupo controle em ambas as dietas. Ainda observamos que, a dieta hiperlipídica eleva a concentração de INF entre animais do grupo controle em relação ao grupo controle mantidos com dieta convencional. Não observamos diferenças na concentração de INF no LBA dos animais sensibilizados e desafiados com OVA.

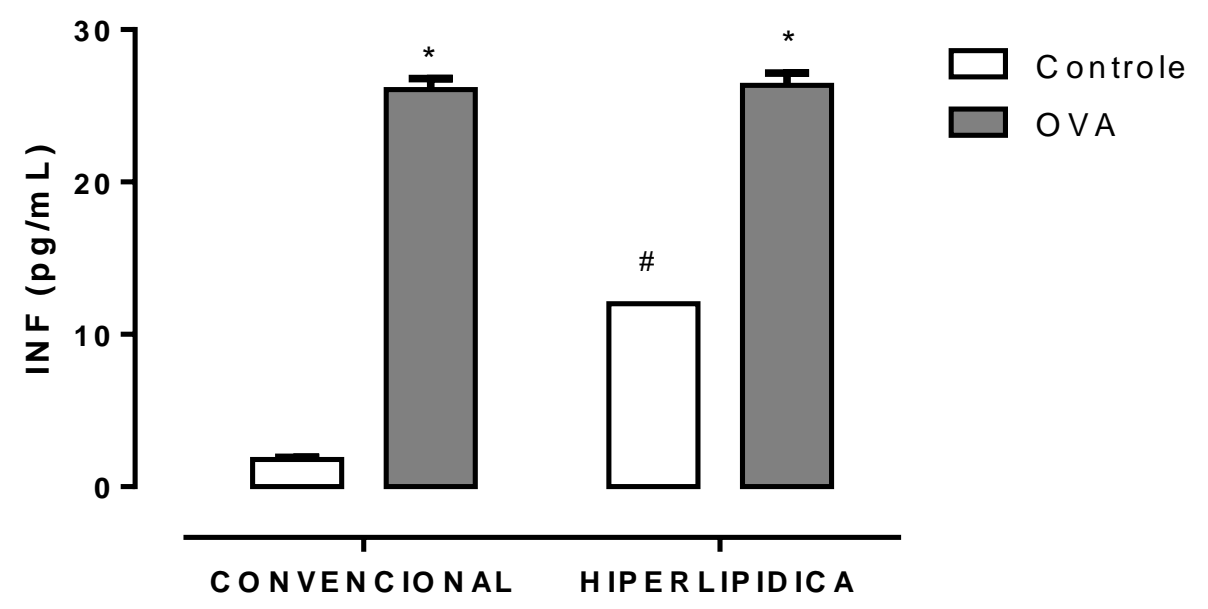

Figura 20 - Efeito do tipo da dieta sobre a concentração de INFY em LBA de camundongos fêmeas de animais controle e animais sensibilizados e desafiados com OVA. Os dados representam a média \pm EPM de 10 animais. * $p<0,05 \mathrm{em}$ relação ao grupo controle. \# $p<0,05$ em relação ao grupo controle sob dieta convencional. 
Em relação a IL-2 (figura 21) nossos dados indicaram que o LBA de animais sensibilizados e desafiados com OVA tiveram aumento da liberação de IL-2, quando comparados com o LBA dos animais do grupo controle em ambas as dietas. Por outro lado, não observamos alterações nas concentrações de IL-2 do grupo controle sob dieta hiperlípidica e convencional.

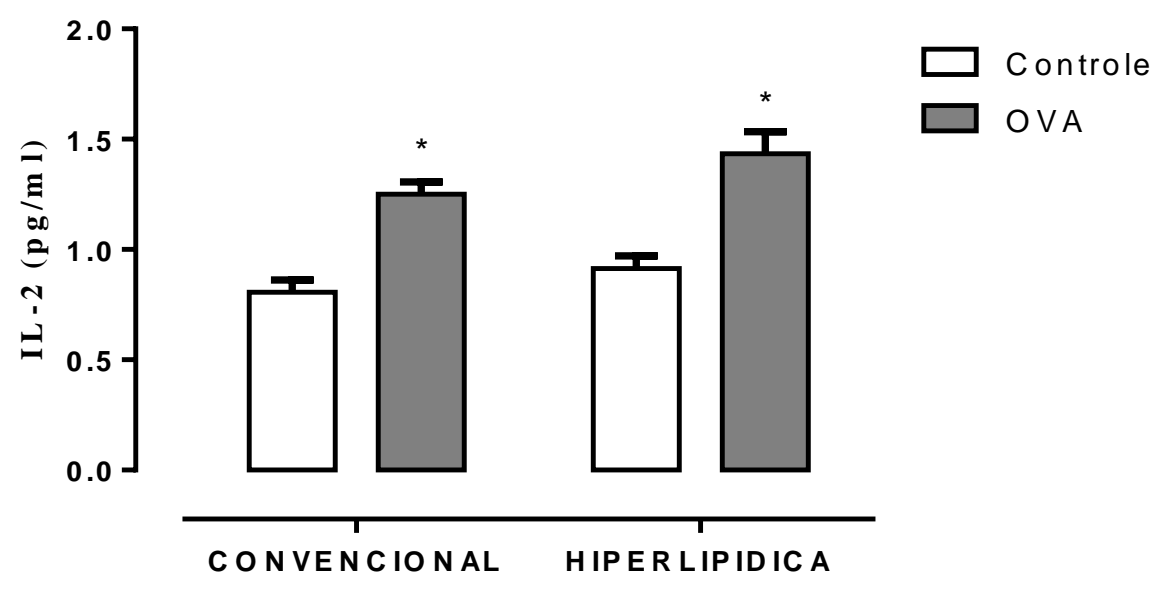

Figura 21 - Efeito do tipo da dieta sobre a concentração de IL-2 em LBA de camundongos fêmeas de animais controle e animais sensibilizados e desafiados com OVA. Os dados representam a média \pm EPM de 10 animais. ${ }^{*} p<0,05$ em relação aos grupos controle. 
Com respeito à IL-10 observamos que, os animais dos grupos sensibilizados e desafiados com OVA tiveram aumento da liberação desta citocina quando comparado com os dados nos animais dos grupos controle mantidos em ambas dietas. Ainda, observamos aumento significativo de IL-10 no grupo controle sob dieta hiperlipídica em relação aos sob dieta convencional. Por fim, observamos um aumento na liberação de IL-10 no LBA dos animais sensibilizados e desafiados com OVA mantidos sob dieta hiperlípidica em relação aos animais sensibilizados e desafiados com OVA mantidos sob dieta convencional.

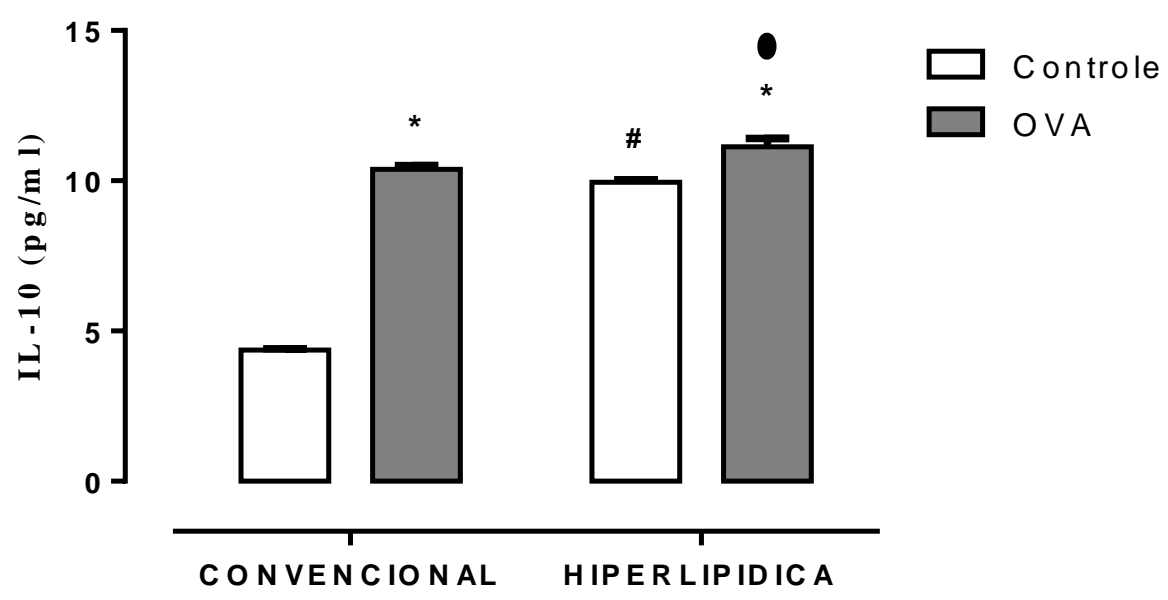

Figura 22 - Efeito do tipo da dieta sobre a concentração de IL-10 em LBA de camundongos fêmeas de animais controle e animais sensibilizados e desafiados com OVA. Os dados representam a média \pm EPM de 10 animais. ${ }^{*} p<0,05 \mathrm{em}$ relação aos animais dos grupos controle mantidos com ambas dietas. \#p<0,05 em relação aos animais que consumiram ração convencional do grupo controle. $\Theta p<$ 0,05 em relação aos animais sensibilizados e desafiados com OVA mantidos com dieta convencional. 
A concentração de IL-6 está representada na figura 23 na qual observamos que animais dos grupos sensibilizado e desafiado com OVA tiveram aumento da sua liberação, quando comparados com os valores obtidos no LBA de animais do grupo controle em ambas as dietas. Além disso, houve aumento da IL-6 no grupo controle sob dieta hiperlipídica em relação ao grupo controle sob dieta convencional. Também observamos um aumento na liberação de IL-6 no LBA dos animais sensibilizados e desafiados com OVA mantidos sob dieta hiperlípidica em relação aos animais sensibilizados e desafiados com OVA mantidos sob dieta convencional.

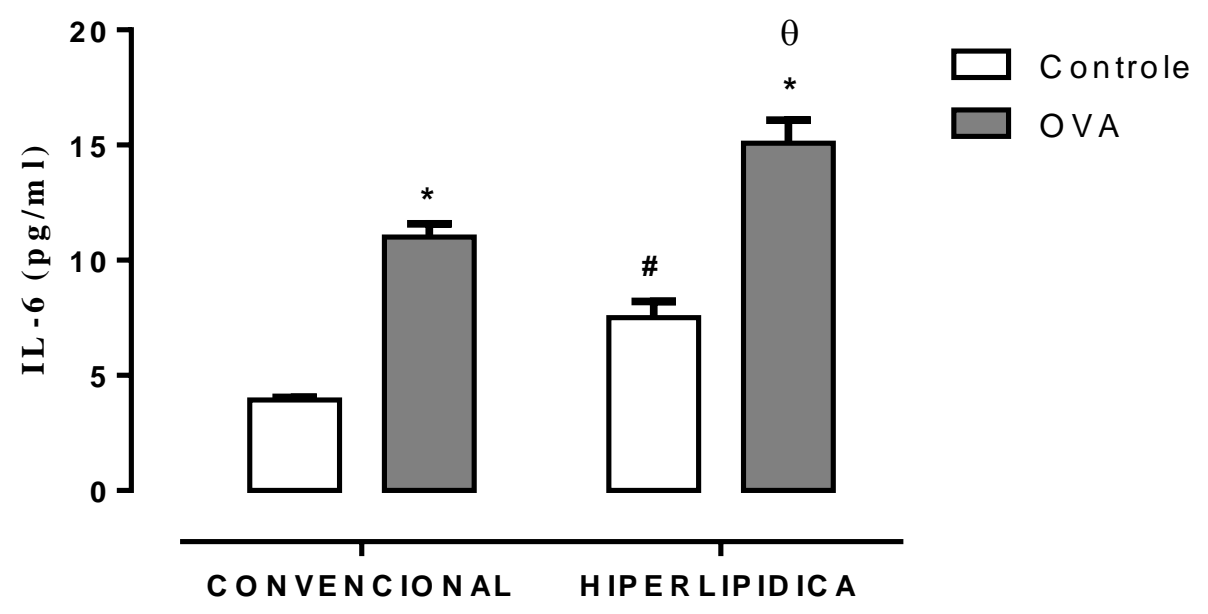

Figura 23 - Efeito do tipo da dieta sobre a concentração de IL-6 em LBA de camundongos fêmeas de animais controle e animais sensibilizados e desafiados com OVA. Os dados representam a média \pm EPM de 10 animais. ${ }^{*} p<0,05 \mathrm{em}$ relação aos animais do grupo controle mantidos com ambas dietas. \# $p<0,05 \mathrm{em}$ relação aos animais do grupo controle sob dieta convencional. $\Theta p<0,05$ em relação aos animais sensibilizados e desafiados com OVA mantidos com dieta convencional. 
Os valores de IL-4 no LBA dos animais estão representados na figura 24. Como pode ser visto, nos grupos OVA mantidos com dieta convencional houve aumento significativo da liberação de IL-4 em relação ao controle. No entanto, no grupo controle mantido sob dieta hiperlípidica houve significativo aumento de IL-4 em comparação com o observado no grupo OVA sob dieta hiperlípidica. Ainda, no grupo mantido com dieta hiperlípidica observamos aumento de IL-4 liberada em comparação com grupo OVA sob dieta convencional.

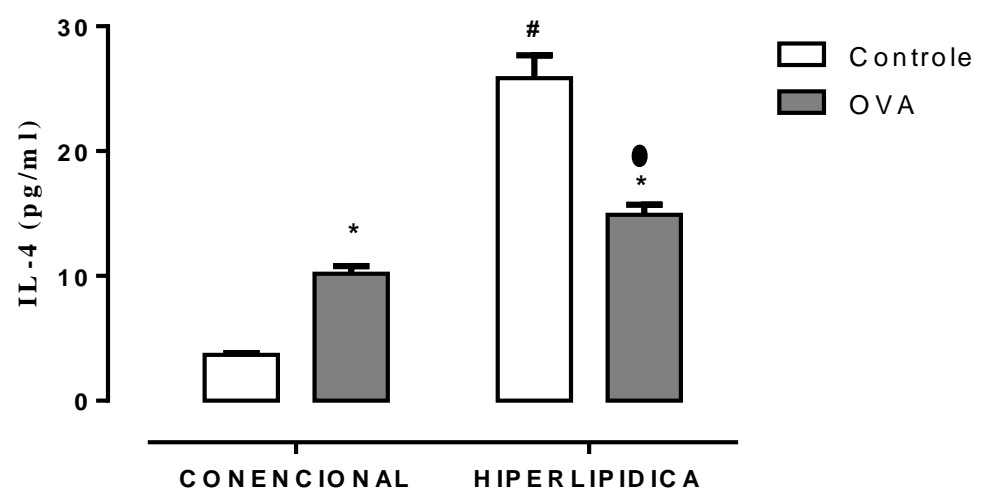

Figura 24 - Efeito do tipo da dieta sobre a concentração de IL-4 em LBA de camundongos fêmeas de animais controle e animais sensibilizados e desafiados com OVA. Os dados representam a média \pm EPM de 10 animais. * $p<0,05$ em relação aos animais do grupo controle mantidos com ambas dietas. \# $p<0,05$ em relação aos animais do grupo controle sob dieta convencional. $\Theta p<0,05$ em relação aos animais sensibilizados e desafiados com OVA mantidos com dieta convencional. 
Com relação à IL-5 (figura 25) observamos aumento significativo no LBA do grupo OVA mantido em ambas dietas. Ainda, observamos diminuição significativa da liberação de IL-5 no grupo controle mantido com dieta hiperlípidica em comparação ao grupo controle mantido com dieta convencional. Por fim, animais do grupo OVA mantidos sob dieta hiperlipídica apresentaram significativa redução de geração de IL-5 em relação aos animais mantidos sob dieta convencional.

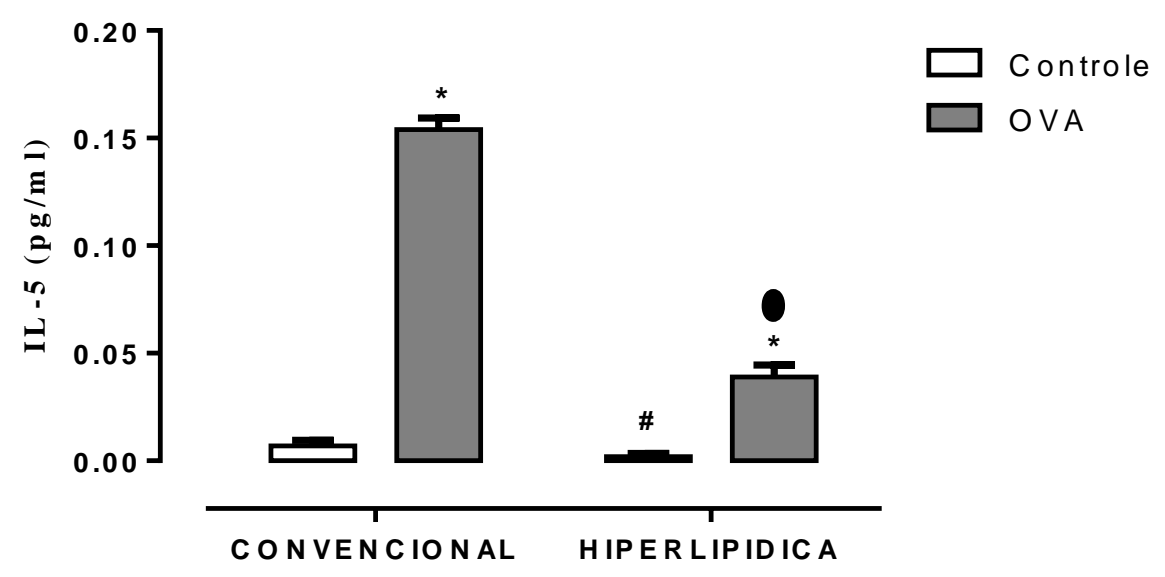

Figura 25 - Efeito do tipo da dieta sobre a concentração de IL-5 em LBA de camundongos fêmeas de animais controle e animais sensibilizados e desafiados com OVA. Os dados representam a média \pm EPM de 10 animais. * $p<0,05$ em relação aos animais dos grupos controles mantidos com ambas dietas. \# $p<0,05$ em relação aos animais do grupo controle sob dieta convencional. $\Theta p<0,05$ em relação aos animais sensibilizados e desafiados com OVA mantidos com dieta convencional. 
$\mathrm{Na}$ figura 26 estão representados os valores obtidos de $\mathrm{IL}-13$. Os dados indicaram aumento da geração desta citocina no LBA dos grupos OVA, mantidos em ambas as dietas. Observa- se também aumento da citocina em relação aos seus respectivos controles no LBA de animais dos grupos controles mantido com dieta hiperlípidica em relação ao grupo controle sob dieta convencional.

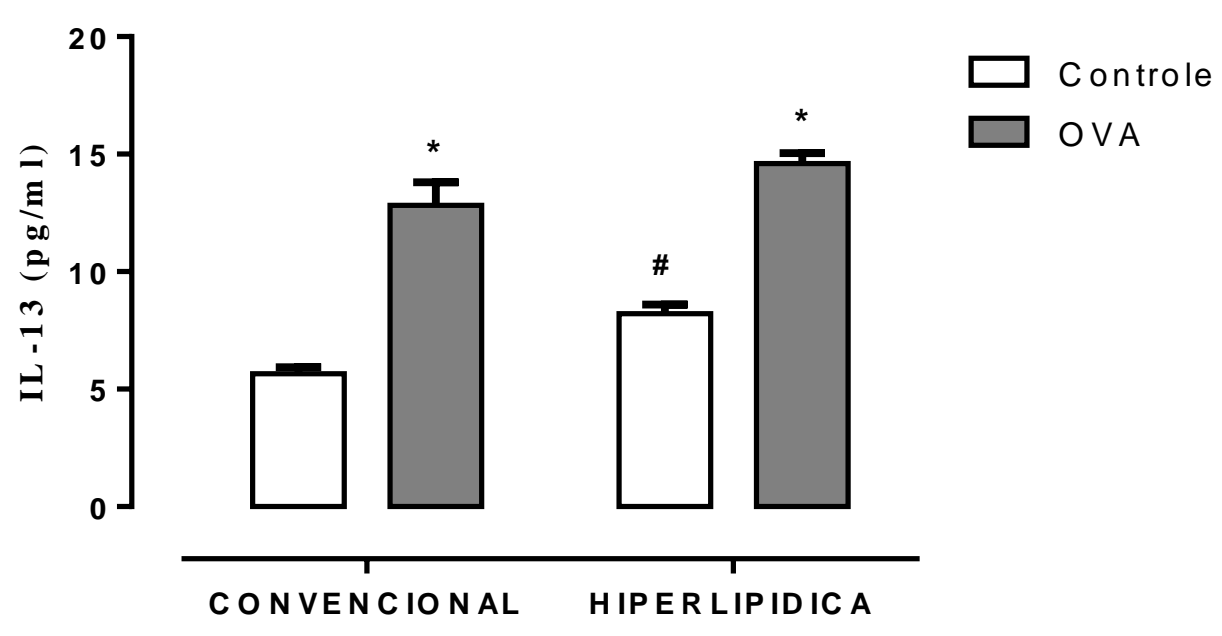

Figura 26 - Efeito do tipo da dieta sobre a concentração de IL-13 em LBA de camundongos fêmeas de animais controle e animais sensibilizados e desafiados com OVA mantidos sob dieta convencional e hiperlipídica. Os dados representam a média \pm EPM de 10 animais. ${ }^{*} p<0,05$ em relação aos animais do grupo controle mantidos com ambas dietas. \# $p<0,05$ em relação aos animais do grupo controle sob dieta convencional. 
Com respeito à IL-17 (figura 27) nossos dados mostraram aumento da geração no LBA dos animais do grupo OVA mantidos com ambas as dietas quando comparados com o observado no respectivo grupo controle. Ainda, o LBA do grupo controle sob dieta hiperlipídica aumentou significativamente a geração de IL-17 em relação ao grupo controle sob dieta convencional. Também observamos aumento da geração de IL - 17 em animais do grupo OVA sob dieta hiperlipídica em relação aos do grupo OVA mantidos sob dieta convencional.

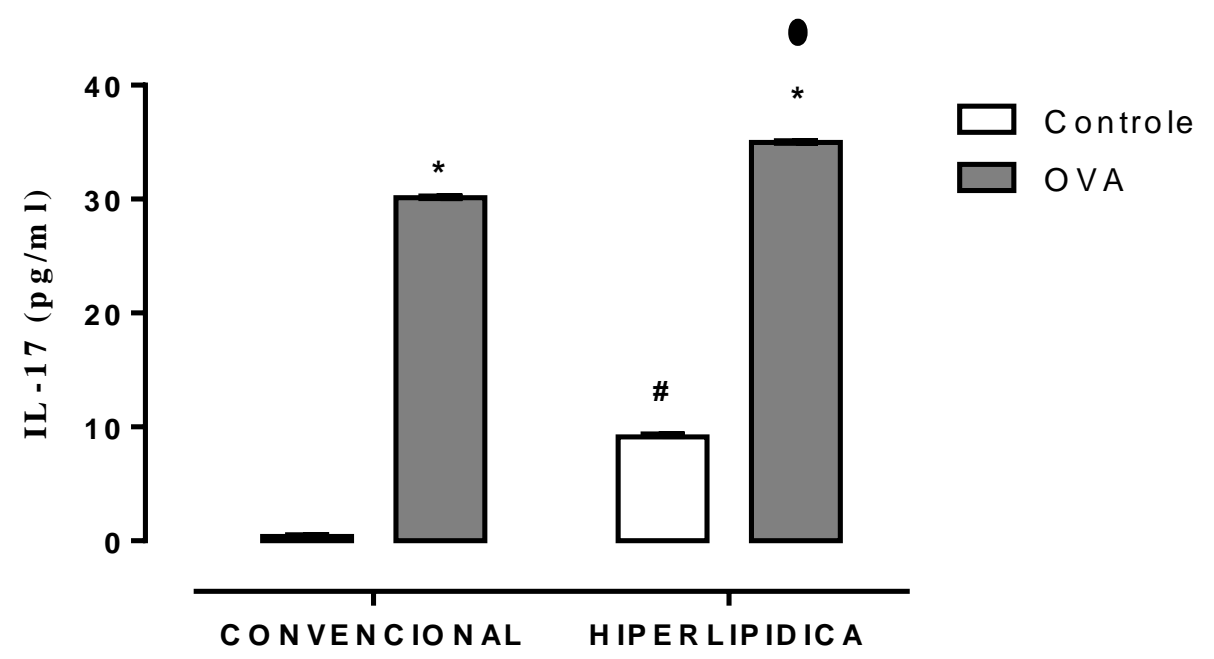

Figura 27 - Efeito do tipo da dieta sobre a concentração de IL-17 em LBA de camundongos fêmeas de animais controle e animais sensibilizados e desafiados com OVA mantidos sob dieta convencional e hiperlipídica. Os dados representam a média \pm EPM de 10 animais. ${ }^{*} p<0,05$ em relação aos animais do grupo controle mantidos com ambas dietas. \# $p<0,05$ em relação aos animais do grupo controle sob dieta convencional. $\Theta p<0,05$ em relação aos animais sensibilizados e desafiados com OVA mantidos com dieta convencional. 


\subsubsection{Análises histológicas e morformétrica do pulmão}

\subsubsection{Coloração de Picro-Sírius}

Nesta parte do estudo (Figura 28) avaliamos a deposição de colágeno nas vias aéreas dos grupos investigados, e observamos aumento significativo da porcentagem de sua deposição nos grupos OVA, em relação aos respectivos grupos controle. Observamos aumento da porcentagem de deposição no grupo controle mantido com dieta hiperlípidica, em relação ao grupo controle mantido com dieta convencional. Por fim, notamos aumento significativo da porcentagem de colágeno no grupo OVA sob dieta hiperlipídica em relação ao seu respectivo grupo sob dieta convencional.

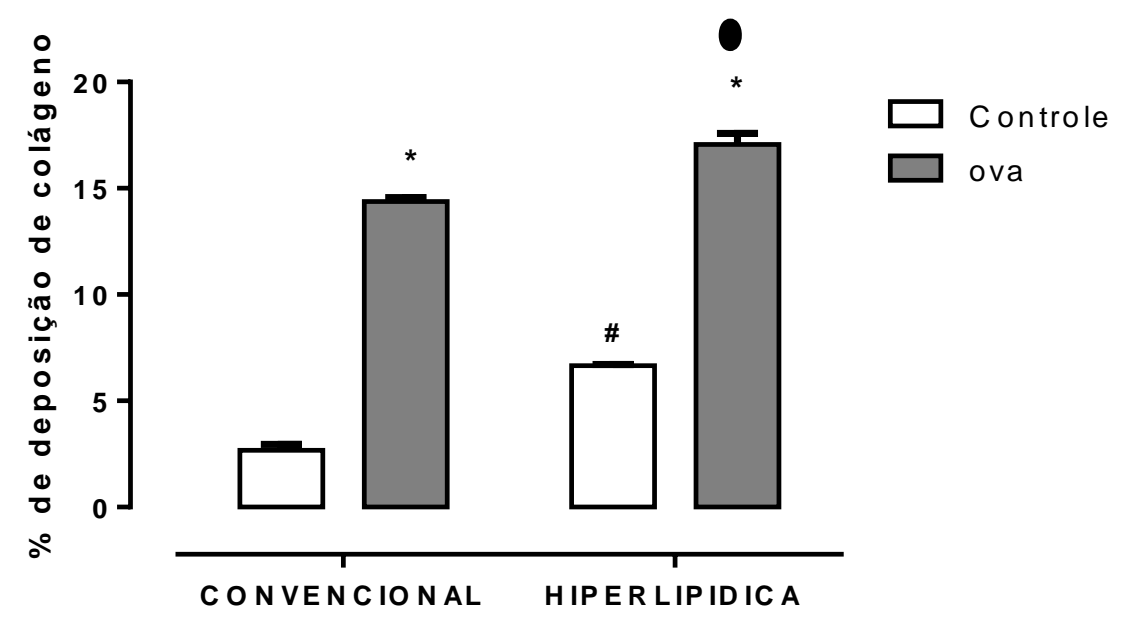

Figura 28 - Efeito do tipo da dieta sobre a porcentagem de deposição de colágeno nas vias aéreas de camundongos fêmeas de animais controle e animais sensibilizados e desafiados com OVA mantidos sob dieta convencional e hiperlipídica. Os dados representam a média \pm EPM de 10 animais. * $p<0,05 \mathrm{em}$ relação aos animais do grupo controle mantidos com ambas dietas. \# $p<0,05 \mathrm{em}$ relação aos animais do grupo controle sob dieta convencional. $\Theta p<0,05 \mathrm{em}$ relação aos animais sensibilizados e desafiados com OVA mantidos com dieta convencional. 
A figura 29 representa corte histológico de pulmão de animais do grupo controle, mantidos sob dieta convencional (A), animais do grupo OVA mantidos sob dieta convencional (B), animais do grupo controle mantidos sob dieta hiperlípidica (C) e animais do grupo OVA mantidos sob dieta hiperlípidica (D). Como pode ser observado, animais do grupo OVA (B e D), possuem maior deposição de colágeno em relação aos animais do grupo controle ( $A$ e $C$ ), ainda animais mantidos sob dieta hiperlípidica ( $C$ e D) possuem um aumento na deposição de colágeno em comparação com animais mantidos com dieta convencional (A e B). 
Figura 29 - Fotomicrografias de cortes histológicos de pulmão corados com Pícro sìrius.

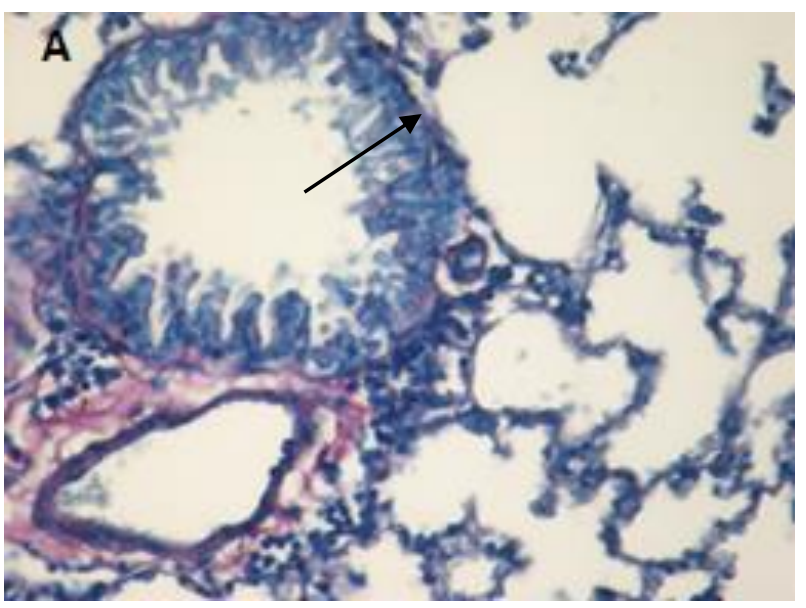

Dieta Convencional - Controle

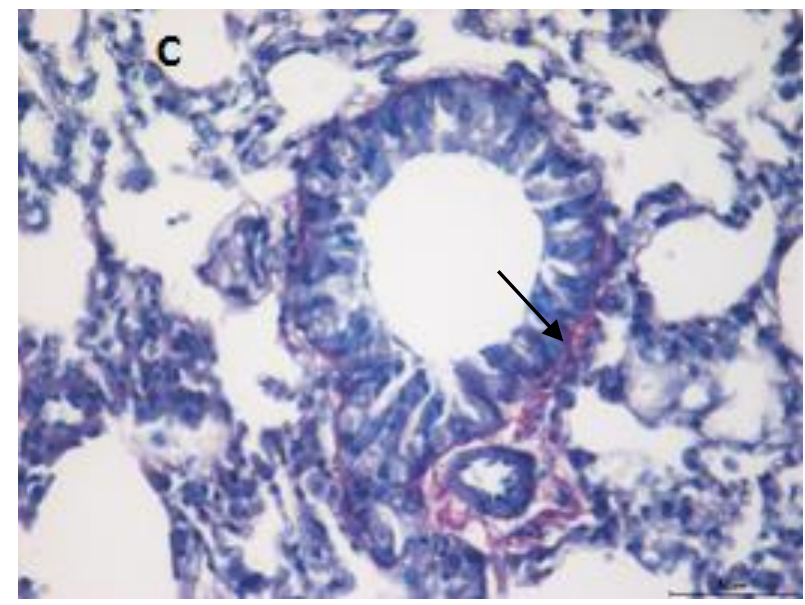

Dieta Hiperlipídica- Controle

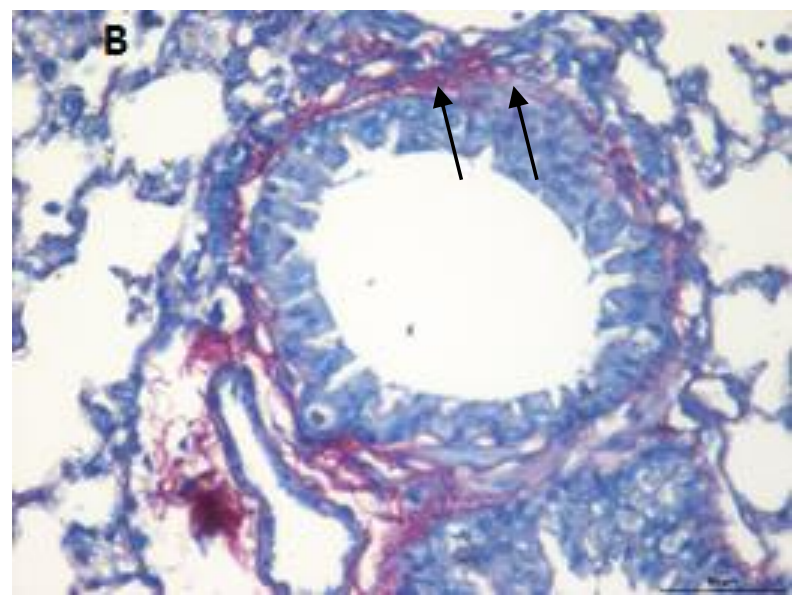

Dieta Convencional - OVA

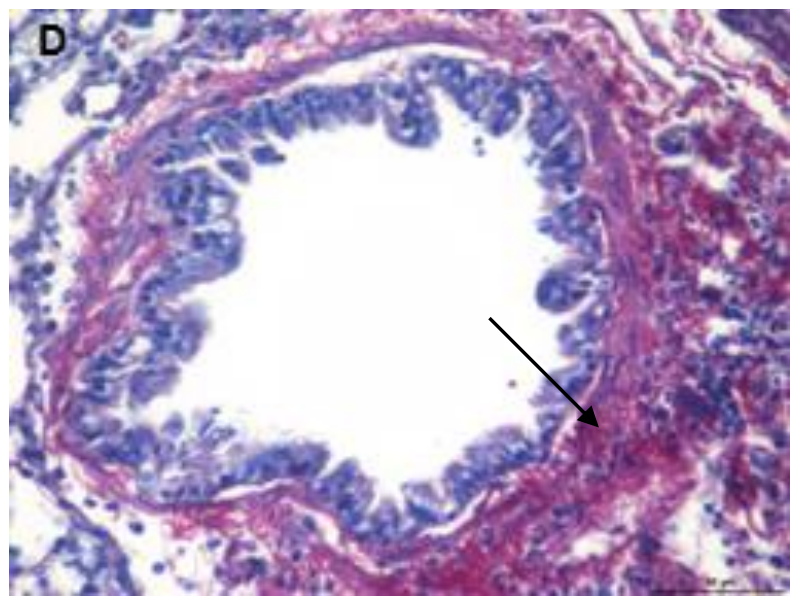

Dieta Hiperlipídica -OVA 


\subsubsection{Coloração de Hematoxilina e Eosina}

A espessura das vias aéreas está representada na figura 30 painel A. Nele observamos aumento significativo de espessura no grupo OVA, mantido em ambas as dietas comparado aos respectivos grupos controle. Ainda, notamos aumento significativo da espessura das vias aéreas no grupo controle mantido com dieta hiperlípidica em relação ao grupo controle sob dieta convencional. Um aumento significativo no grupo OVA mantido com dieta hiperlipídica em comparação com o grupo OVA sob dieta convencional, também foi detectado.

No painel $\mathrm{B}$, da figura 30 observa - se aumento da porcentagem de músculo das vias aéreas de animais do grupo OVA mantidos sob ambas as dietas em relação aos respectivos grupos controle. Também notamos aumento da porcentagem de músculo das vias aéreas em animais do grupo OVA sob dieta hiperlipídica em relação aos animais do grupo OVA sob dieta convencional. Por fim, tiveram aumento da porcentagem de musculo liso animais do grupo controle sob dieta hiperlípidica em relação ao observado no grupo controle mantido sob dieta convencional. 
A

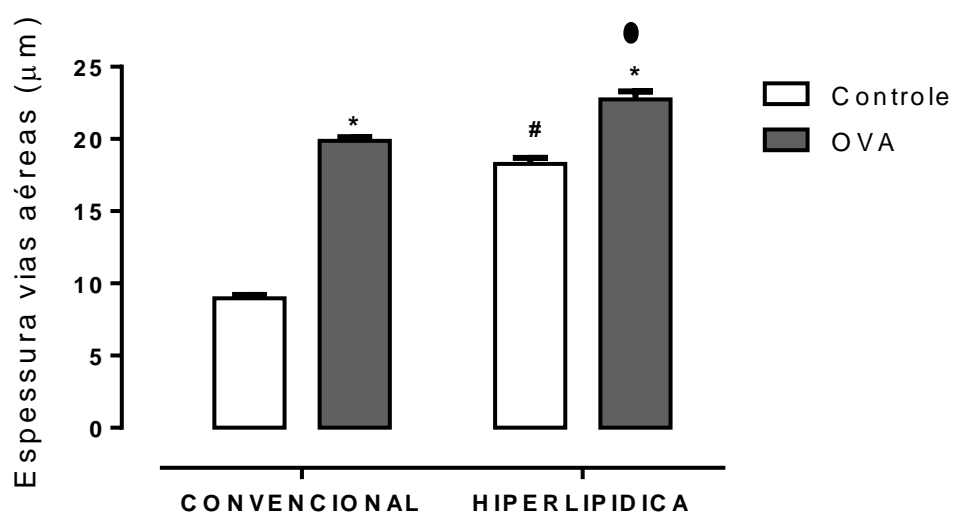

B

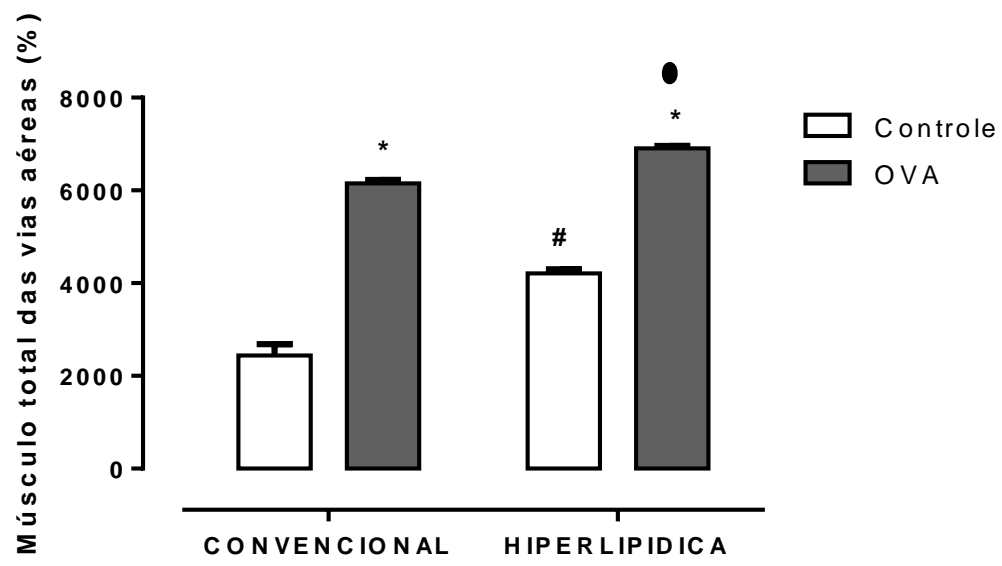

Figura 30 - Efeito do tipo da dieta sobre a espessura das vias aéreas (painel A) e da porcentagem de musculo das vias aéreas (painel B) de camundongos fêmeas de animais controle e animais sensibilizados e desafiados com OVA mantidos sob dieta convencional e hiperlipídica. Os dados representam a média \pm EPM de 10 animais. * $p<0,05$ em relação aos animais do grupo controle mantidos com ambas dietas. \# $p<0,05$ em relação aos animais do grupo controle sob dieta convencional. $\Theta p<$ 0,05 em relação aos animais do grupo OVA mantidos com dieta convencional. 
A figura 31 representa corte histológico de pulmão de animais do grupo controle, mantidos sob dieta convencional (A), animais do grupo OVA mantidos sob dieta convencional $(B)$, animais do grupo controle mantidos sob dieta hiperlípidica (C) e animais do grupo OVA mantidos sob dieta hiperlípidica (D). Como pode ser observado, animais do grupo OVA (B e D), possuem maior espessura e maior porcentagem de músculo liso em relação ao animais do grupo controle $(A$ e $C$ ), ainda animais mantidos sob dieta hiperlipídica ( $C$ e $D$ ) possuem uma maior espessura e maior porcentagem de músculo liso em relação aos animais mantidos sob dieta convencional (A e B).Por fim animais do grupo OVA mantidos sob dieta hiperlipídica (D) possuem uma maior espessura e maior porcentagem de músculo liso em relação aos animais do grupo OVA mantido sob dieta convencional (B).

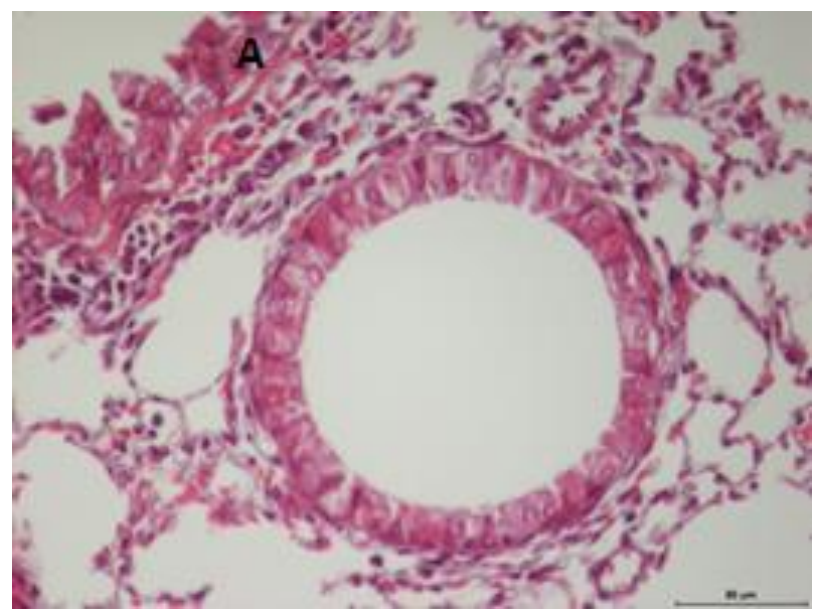

Dieta Convencional - Controle

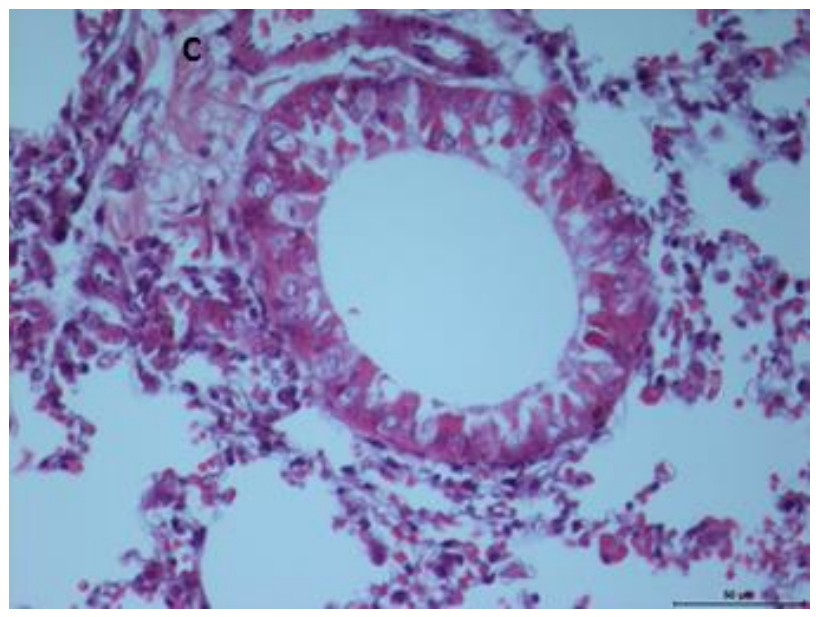

Dieta Hiperlipídica - Controle

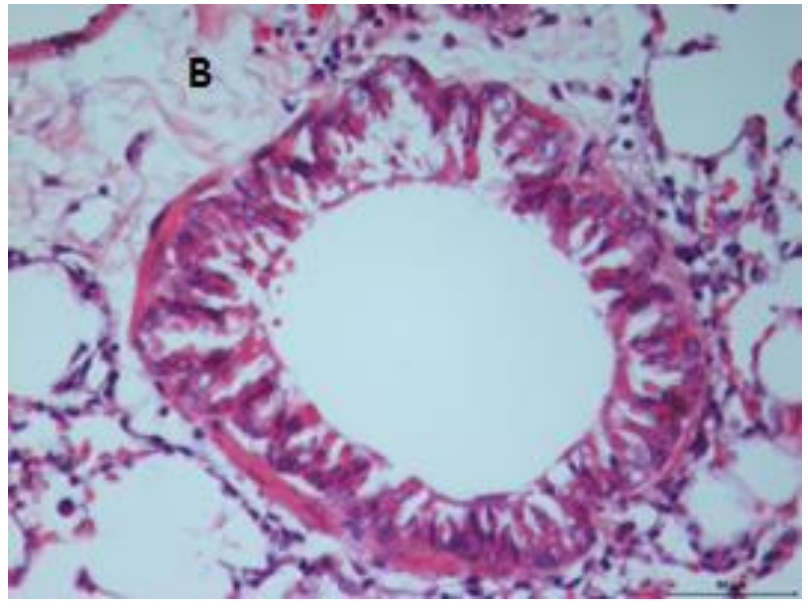

Dieta Convencional - OVA

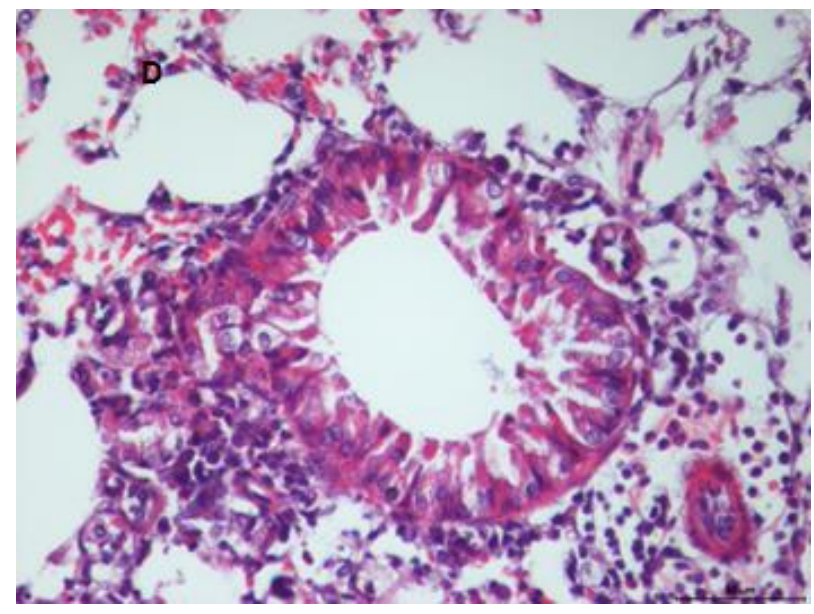

Dieta Hiperlipídica- OVA 


\section{DISCUSSÃO}

Neste estudo, investigamos a interferência da obesidade sobre a inflamação pulmonar em modelo murino de asma experimental com fenótipo neutrofílico. A base deste estudo recai sobre a inflamação de que mulheres obesas desenvolvem asma com um fenótipo neutrofílico a qual é refratária ao tratamento com corticoides (PETERS et al., 2016). Neste sentido, tais aspectos foram essenciais para a condução dos estudos, a saber, desenvolver os modelos de obesidade e o de asma neutrofílica. $O$ modelo de obesidade foi desenvolvido de acordo com os estudos existentes na literatura (BURCELIN et al., 2002; CAMPOS et al., 2014; MALAFAIA et al., 2013; NERY, et al., 2011; PELEGRINI et al., 2013; SENGERS et al., 2011; WHITE et al.; 2013). Por outro lado, o modelo de asma neutrofílica foi determinado em relação com a Dra Yanira Riffo-Vasquez pesquisadora do Institute of Pharmaceutical Science - King's College London.

Induzimos a obesidade por meio do oferecimento a camundongos fêmeas, de uma dieta hiperlipídica e, a seguir, caracterizamos o modelo de asma neutrofílica. A base deste estudo recai sobre a existência de dados na literatura acerca da associação entre obesidade e asma (CALIXTO et al., 2010). Todavia, como será discutido adiante, estudos sobre a asma neutrofílica ainda são escassos.

A obesidade em todo mundo mais que duplicou desde 1980, e de acordo com a Organização Mundial da Saúde, em 2014, mais de 1,9 bilhão de pessoas estão obesas (http://www.who.int/mediacentre/factsheets/fs311/en/). Existem diversos modelos de obesidade induzida por dieta hiperlipídica em animais de experimentação com variações nos protocolos e nas linhagens de animais usados (BURCELIN et al., 2002; CAMPOS et al., 2014; MALAFAIA et al., 2013; NERY, et al., 2011; PELEGRINI et al., 2013; SENGERS et al., 2011; WHITE et al.; 2013). O tempo de indução da obesidade por dieta hiperlipídica varia de 8 a 20 semanas. Todavia, neste estudo, demonstramos que camundongos fêmeas BALB/c, que ingeriram dieta hiperlipídica durante 10 semanas, apresentaram características do quadro de obesidade. De fato, nesses animais observamos aumento da massa corpórea e dos depósitos de gordura retroperitoneal e gonadal quando comparados aos dados obtidos em animais que receberam dieta convencional. Além disso, o consumo de ração hiperlipídica por 10 semanas promoveu alterações metabólicas típicas da 
obesidade, tais como elevação da glicemia, dos níveis séricos de colesterol total, do HDL e triglicérides. Tomados em conjunto, estes dados demonstram a efetividade da dieta hiperlipídica durante 10 semanas. Em reforço aos nossos dados estão as evidências experimentais (BURCELIN et al., 2002; CAMPOS et al., 2014 MALAFAIA et al., 2013; SENGER et al., 2011; WHITE et al.; 2013). No trabalho realizado por NERY, et al., (2011), observou - se também alterações metabólicas após 10 semanas de ingesta de dieta rica em gordura. PELEGRINI et al., (2013) também demonstraram que animais mantidos com dieta hiperlipídica sofrem alterações metabólicas, como aumento de glicemia, aumento de colesterol e ganho de massa corpórea em comparação com animais mantidos sob dieta convencional. Neste estudo, nós avaliamos a presença de inflamação sistêmica, mas existem dados na literatura que confirmam que na obesidade existe inflamação de baixo grau (RASMUSSEM et al., 2014), na qual diversas citocinas são geradas pelo tecido adiposo, podendo atingir a circulação (GRAÇA et al., 2010; KOPELMAN, 2000; PRADO et al., 2009).Estudos induzidos por Peters et al., (2016) demonstraram que aumento de IL-6 pode estar relacionado com a obesidade e agravamento da asma, ainda observa-se aumento de citocinas como TNFa, INF, IL-1 1 , IL-1, IL-2, mediadores originários de adipócitos e macrófagos, ativados no tecido adiposo, que contribui para uma piora na asma em pacientes obesos. Somando-se a isto, tais citocinas inflamatórias podem alterar a função pulmonar ativando células vasculares endoteliais, fibroblastos nas vias aéreas e células musculares lisas das vias respiratórias. Ainda, a IL-17, IL-2 e IL-6 podem influenciar a diferenciação de células Tho em células Th1 (MOORE et al., 2010; PETERS et al., 2016, SINGH et al, 2016; YANG et al., 2007; WENZEL et al., 2010). Em nossos estudos, como descrito por Peters et al., (2016), observamos aumento de citocinas TNFa, INF, IL-1 $\beta$, IL-2 e IL6 , relacionados aos animais mantidos sob dieta hiperlipídica e considerados obesos. Portanto, consideramos que a existência de um grau de inflamação prévia decorrente do estado de obesidade poderia interferir com o curso da resposta inflamatória pulmonar observada na asma. Em estudo, realizado por Shuterland et al., (2007), observou-se que a asma relacionada a pessoas obesas apresenta um perfil inflamatório não eosinofílico característico da resposta $T{ }_{1}$, onde os neutrófilos têm papel de destaque, em lavado broncoalveolar de pacientes obesos, onde observa - se um aumento de neutrófilos em comparação ao de eosinófilos, 
observou-se que asmáticos obesos também apresentam níveis baixos de lgE (SIDELEVA et al., 2012). É interessante notar que o mecanismo base para relação entre obesidade e asma permanece obscuro. Entretanto, fatores mecânicos como redução dos volumes pulmonares, limitação torácica e aspectos da inflamação sistêmica relacionadas com a obesidade, incluindo mudanças na regulação de mediadores inflamatórios podem contribuir para a piora da asma (CAPELO et al., 2015; SHORE, 2008; WANG et al., 2015).

Estudos realizados por Scott et al., (2013) com pacientes asmáticos mostraram que a redução de peso se associa melhora da função pulmonar. Takeda, (2013), também demonstraram que uma dieta de 10 semanas associada a exercícios físicos com redução de peso de 10\% resultou em melhoria clínica de pacientes asmáticos, sugerindo que a redução do tecido adiposo possa estar associada à redução do perfil inflamatório.

As características clínicas da asma são muito variadas e a maioria dos pacientes tem um fenótipo mais leve, o qual é facilmente controlado por fármacos agonistas beta adrenérgicos inalatórios e baixas doses de corticoides. No entanto, existe um subconjunto de pacientes que apresenta a forma mais grave da doença, que se caracteriza por ser resistente à corticoterapia (NAKAGOME et al., 2012; PETERS et al., 2016). De interesse, aparentemente, mulheres obesas na menopausa representam significativo grupo de risco (RASMISSEN et al., 2014). Erzurum et al., (2015) constataram maior prevalência de mulheres obesas na menopausa com asma grave. Entre os fatores envolvidos com a asma estariam os hormônios sexuais femininos dos quais regulam receptores $\beta 2$ adrenérgicos, fazendo com que ocorra uma resposta a broncodilatores (PAIVIMEN et al., 2014). É sabido que receptores de progesterona são expressos no epitélio das vias aéreas e que a progesterona promove inibição da frequência respiratória e dos batimentos ciliares o que pode impactar no transporte muco ciliar durante o ciclo menstrual entre as mulheres (MC-CALISTER et al., 2013). Adicionalmente a redução do estrogênio aumenta a produção de citocinas como IL-4 e IL-13 observados em mulheres asmáticas obesas na menopausa, o que contribui para uma piora da asma (WANG et al., 2015). À luz destas evidências a conexão entre obesidade e asma parecem consistentes estudos realizados por Maniscalco et al., (2008) observaram que mulheres obesas asmáticas apresentaram níveis significativos de mediadores 
inflamatórios no tecido adiposo e no lavado broncoalveolar, em comparação com mulheres asmáticas com peso normal.

De forma geral, os modelos experimentais de asma usados são desencadeados em animais de experimentação utilizando um protocolo de sensibilização que direciona a resposta do sistema imunológico para a geração de citocinas com um perfil conhecido como perfil Th2. Neste perfil, IL-4, IL-5, entre outras citocinas e os eosinófilos ocupam lugar de destaque (NEWCOMB et al., 2013). Admite-se que são os produtos tóxicos derivados dos eosinófilos notadamente a proteína básica principal, que promove a destruição do epitélio brônquico e com isto advém a hiper-reatividade brônquica (FAHY, 2009). JACOBSEN et al., (2016) mostraram que na asma, eosinofílica, a desgranulação de eosinófilos no pulmão contribui para o remodelamento pulmonar e hiperresponsividade das vias aéreas. Para tanto, na prática clínica, pacientes com asma eosinofílica utilizam fármacos como broncodilatadores e/ou corticoides inalatórios, como a budesonida, para alívio e controle com eficácia comprovada. No entanto, alguns pacientes não respondem adequadamente a esses fármacos (VOGEL et al., 2016). O nosso estudo apontou para o outro fenótipo da asma, identificado como asma neutrofílica e que sabidamente é refratária aos corticoides, além disso por ser mais comum em mulheres obesas. Estudos prévios de nosso laboratório revelaram o papel modulador do estradiol no controle da resposta asmática em ratas e em camundongos fêmeas fortalecendo o papel dos hormônios sexuais femininos no controle da resposta asmática (de OLIVEIRA et al., 2010; RIFFO-VASZQUEZ, 2007). Apesar do mencionado, o papel dos esteroides sexuais na asma neutrofílica necessita de mais estudos e mais, modelos experimentais que visem a investigar o perfil Th1 na asma, notadamente, o papel dos neutrófilos até onde pudemos observar ainda não estão disponíveis. É interessante ressaltar que, a literatura clínica revela que o lavado broncoalveolar de pacientes asmáticas resistentes a corticoides é rico em neutrófilos (KIKUCHI et al., 2005; MOORE et al., 2010, WENZEL et al., 2015). Assim, estabelece-se nesses pacientes a conexão entre a resistência da asma ao corticoide com a presença de neutrófilos no pulmão. Os dados existentes na literatura ainda não permitem indicar como os neutrófilos medeiam as alterações na asma tais como a hiper-reatividade brônquica (NEWCOMB et al., 2013). Todavia, o envolvimento dessas células na asma de difícil 
controle (resistente aos esteroides) está bem definido. Apesar do mencionado, recentes estudos indicam que pacientes asmáticos apresentam alteração da atividade funcional de neutrófilos, sugerindo que o controle da asma neutrofílica possa depender do estado funcional dessas células, notadamente em condições de infecção (TANG et al., 2015). A asma neutrofílica caracteriza-se na clínica por números limitados de eosinófilos nas vias aéreas. De fato, os exames de escarro de pacientes com asma grave demonstram aumento no número de neutrófilos em comparação a pacientes com asma alérgica, ainda o lavado broncoalveolar destes pacientes revelam quantidade maior de neutrófilos em comparação a pacientes saudáveis e naqueles com asma eosinofílica (REYNOLD et al., 2016). Os trabalhos de coorte realizados por Haldar et al., (2008) e KIM et al., (2013) observaram que, mulheres obesas, na menopausa, apresentaram perfil mais grave de asma, estes autores indicaram que mulheres com este perfil utilizam mais corticoides inalatórios que mulheres asmáticas com IMC inferior a $30 \mathrm{Kg} / \mathrm{m}^{2}$, ainda detectaram baixa contagem de eosinófilos no lavado broncoalveolar dessas pacientes. Os estudos, portanto, sugerem mais uma vez, a conexão entre a asma e obesidade em mulheres indicando que estudos sobre este tema se revestem de importância adicional. Associada à percepção da relevância da obesidade como uma pandemia, estão os dados acerca do elevado número de pacientes asmáticos, o qual é estimado ser da ordem de 235 milhões de pessoas no mundo (WHO, 2016) e, destas, uma parcela significativa é composta de mulheres.

No presente estudo desenvolvemos um modelo experimental de asma murina que procura mimetizar a asma neutrofílica e sua principal característica que é a refratariedade ao tratamento com corticoide. É bem documentado que o perfil Th2 na asma alérgica está associado a níveis elevados de IgE e não de IgG (BERSTEIN et al., 1964), a qual se encontra mais elevada em um perfil Th1. Nossos dados indicaram aumento da atividade de lgG em animais sensibilizados e desafiados com OVA, o qual revela inflamação pulmonar neutrofílica, em comparação com animais do grupo controle. De maneira a caracterizar melhor o modelo neutrofílico de asma quantificamos a $\operatorname{lgG}$ e $\lg E$ em comparação com o modelo alérgico trivialmente utilizado na literatura. Nossos resultados indicaram aumento da atividade da IgG em comparação com a IgE no LBA de animais sensibilizados e desafiados com OVA. No entanto, nossos estudos demonstram aumento de $\lg E$ no soro de animais 
sensibilizados e desafiados cm OVA em comparação com lgG. Está bem estabelecido na literatura que a $\lg \mathrm{E}$ caracteriza a existência de doença alérgica e asma é uma delas (CHUNG et al., 2015). No presente estudo, após a sensibilização dos animais desafiados com OVA detectamos aumento significativo do número total de células recuperadas no LBA nos animais mantidos com as dietas hiperlipídica (DH) e convencional (DC). Ainda, observamos que animais obesos apresentaram aumento significativo das células recrutadas em relação aos animais com dieta convencional. Estes dados indicaram que em nosso modelo a obesidade reforça 0 estado inflamatório pulmonar, e sugere que indivíduos obesos são mais sensíveis. É interessante notar que a análise do perfil de células inflamatórias recuperadas no LBA dos animais sensibilizados e desafiados com OVA revelaram significativo aumento de neutrófilos e de eosinófilos e redução do número de células mononucleares em ambas as dietas. É interessante notar que houve aumento no número de neutrófilos em relação ao número de eosinófilos de animais sensibilizados e desafiados com OVA, no modelo proposto para estudarmos a asma neutrofilica. Ainda, o LBA de animais obesos sensibilizados e desafiados apresentou quantidade de eosinófilos mais acentuada do que a observada em animais do mesmo grupo mantidos com dieta convencional.

Nossos resultados estão alinhados com evidências clinicas mostrando que, pacientes obesos com asma neutrofílica e com índice de eosinófilos aumentados, podem estar associados à gravidade da asma. Segundo Caar et al., (2016) o recrutamento de neutrófilos pode estar associado com a inflamação eosinofílica. Eosinófilos têm papel no recrutamento de quimiocinas e citocinas inflamatórias, contribuindo assim para o remodelamento das vias aéreas e gravidade da asma. Vale ressaltar que no contexto da interação obesidade/asma, Calixto et al., (2010), usando modelo murino, em machos, de inflamação pulmonar alérgica, mostrou que a obesidade aumenta o número de eosinófilos na medula óssea e que a obesidade prolonga o seu tempo de permanência na região brônquica. Todavia, nossos dados indicaram que o perfil de neutrófilos nos grupos sob dieta hiperlipídica e dieta convencional se sobrepõe ao dos eosinófilos, indicando a existência de asma neutrofílica. Apesar do mencionado, nós não encontramos diferenças no perfil de neutrófilos entre os grupos mantidos com dieta convencional e dieta hiperlipídica, sugerindo que na obesidade o recrutamento de neutrófilos não foi prejudicado. 
Porém, é possível que a obesidade possa afetar a atividade funcional dos neutrófilos. Neste estudo, nós identificamos que a atividade de mieloperoxidase bem como a de eosinoperoxidase estão mais elevadas nos animais obesos sensibilizados e desafiados. Em síntese, estes resultados e aqueles referentes às $\lg G$ e $\operatorname{lgE}$, demonstram a caracterização parcial do modelo de asma neutrofílica. Além disso, existe um componente eosinofílico na obesidade que parece exacerbar na asma experimental. Estes dados devem ser avaliados também à luz da ocorrência do estado pró-inflamatório de baixa intensidade nos animais obesos, 0 qual poderia interferir com a atividade funcional dos eosinófilos e de neutrófilos. Vale lembrar que, a EPO pode também ser tóxica e lesiva para vários tecidos incluindo pulmão (CAAR et al; 2016). Ainda, o pulmão de animais mantidos com dieta hiperlipídica, têm maior atividade de MPO em relação aos não obesos. Como mencionado anteriormente, a asma neutrofílica tem por característica ser resistente a tratamentos com corticoides. De maneira a caracterizar farmacologicamente 0 modelo de asma neutrofílica, os animais foram tratados com budesonida. Nossos dados indicam que, o tratamento com a budesonida não foi eficaz em reduzir o recrutamento de neutrófilos para o pulmão, sugerindo que nesse modelo observamos resistência ao corticoide. Esta sugestão se reforça quando observamos que em modelo de asma alérgica o mesmo protocolo de tratamento foi eficaz em prevenir o aumento de eosinófilos no pulmão após o desafio alérgico. Vale lembrar que estes estudos foram conduzidos para melhor caracterizar o modelo e por esta razão foram realizados em animais não obeso. De acordo com a American Thoracic Society e a European Respiratory Society (ATS/ERS) a asma grave é definida como uma asma a qual os corticoides não a controlam (CHUNG et al., 2014).

Talvez a característica mais importante da asma seja a limitação do fluxo aéreo e suas consequências para a melhora pulmonar. Nesse contexto, as alterações funcionais das vias aéreas no individuo asmático se associam à limitação do fluxo das vias aéreas, na qual pode - se observar mudanças no recolhimento elástico e aumento de resistência das vias aéreas (O’TOOLE, 2016). Assim, nesta fase do estudo investigamos a resistência das vias aéreas $(\mathrm{Rn})$, a resistência do parênquima pulmonar $(\mathrm{G})$ e a elastância do parênquima pulmonar $(H)$ dos animais submetidos à asma neutrofílica. Nossos resultados apontam que, animais obesos e não obesos desenvolveram aumento significativo da resistência das vias aéreas e 
do parênquima pulmonar. Por outro lado, esses animais revelaram redução da elastância pulmonar. No geral, nossos dados indicaram que no modelo de asma neutrofílica, independentemente da obesidade ocorreram alterações na mecânica pulmonar. Estes resultados embora reforcem a caracterização do modelo de asma neutrofílica, sugerem que o componente da obesidade em fêmeas não exerceu papel determinante. Por outro lado, como a literatura clínica revela que mulheres obesas na menopausa podem desenvolver piora da asma, é possível que nossos resultados tenham sido modulados pelos hormônios sexuais femininos, uma vez que os animais utilizados estavam com seus ovários conservados e, portanto, eram hormonalmente ativas. Além disso, os nossos estudos foram conduzidos em animais com inflamação pulmonar contendo eosinófilos, neutrófilos e com remodelamento já instalados. Eventualmente o grau de inflamação crônica tinha sido excessivo obscurecendo o componente modulador da obesidade.

Dando sequência a caracterização do modelo, investigamos os mesmos parâmetros da mecânica pulmonar em animais não obesas submetidos ao modelo de asma neutrofilica e alérgica, e avaliamos o efeito do tratamento com budesonida. Nossos dados indicaram significativa redução da resistência das vias aéreas, da resistência do parênquima e da elastância nos animais com asma eosinofílica tratados com budesonida. Em contraste, a mecânica pulmonar dos animais com asma neutrofílica não foi afetada pelo tratamento com o corticoide. Em conjunto, nossos dados permitem inferir que o modelo de asma neutrofílica se alinha aos parâmetros descritos na literatura clínica da asma (CHUNG et al., 2014).

A percepção que temos do modelo de asma neutrofílica é a de que as citocinas geradas são também moduladoras do fenótipo inflamatório. Além disso, a obesidade por causar uma inflamação de baixo grau, também poderia interferir no perfil de citocinas geradas. Neste contexto, quantificamos citocinas no LBA. Nossos dados indicaram que a obesidade elevou os níveis de TNFa, IL-2, IL-4, IL-6, IL-10, IL-13, IL-17 e INF. Por outro lado, reduzimos os valores de IL-5. Estes dados sugerem que o pulmão dos animais obesos se encontra em um estado inflamatório basal, fato que se alinha aos estudos indicando a obesidade como fator de indução da inflamação sistêmica. De interesse foi observar que no geral e na vigência da asma neutrofílica observamos redução de IL-5, IL-4, aumento de IL-6, TNFa, IL-1 $\beta$, INFY, IL-17 e IL-13. Esses resultados são interessantes pois podem sugerir que o 
balanço Th1/Th2 está sob influência da obesidade, e pode ser desviado para um perfil Th1 na vigência da asma neutrofílica. Vale lembrar que, este perfil não foi acompanhado por um aumento exuberante de neutrófilos no LBA dos animais. Assim, sugerimos que a obesidade pode interferir, como já mencionado com a atividade funcional dos neutrófilos. Adicionalmente, é possível que o balanço $\mathrm{TH} 1$ na asma neutrofílica possa interferir com o remodelamento das vias aéreas. Uma possibilidade de compreender nossos dados baseia - se no fato de que, a obesidade por si, estimula a leptina aumentando a geração TNFa, IL-2, IL-6 (PABON et al., 2016). Ainda, estudos sugerem que tais citocinas por estarem ligadas á síntese de leptina podem modular a gravidade da asma em pacientes obesas (MC-CALLISTER et al., 2009). Neste estudo, investigamos também aumento de IL-1 $\beta$ no LBA de animais obesos com asma neutrofílica. É sabido que a IL-1 é importante agente quimiotáxico para neutrófilos. Some -se a isto que animais obesos têm maior concentração de IL-1ß, e maior gravidade de asma (SIDELEVA, 2012). Então, nossos dados sugerem interação da IL-1 $1 \beta$ com a obesidade e a asma neutrofílica. Estudos realizados por Gao (2015) indicaram aumento significativo de IL-1 $\beta$ e IL-6 em pacientes com asma neutrofílica em comparação com pacientes com asma eosinofílica.

Nossos dados sugerem que a resposta imune desencadeada nos animais sensibilizados com OVA e adjuvante completo de Freund se direciona para o perfil Th1. De fato, a atividade de IgG no LBA dos animais foi maior do que a de $\lg \mathrm{E}$. No soro embora não tenhamos observado níveis maiores de $\lg \mathrm{G}$ do que $\lg \mathrm{E}$, a relação com o grupo controle sugere que o componente Th1 é mais intenso na asma neutrofílica. No geral, esses dados estabelecem a caracterização do modelo. Vale salientar que, a análise comparativa com o modelo alérgico (Th2) com o neutrofílico (Th1) da asma experimental confirmou maior frequência de eosinófilos neutrófilos quando os animais foram sensibilizados e desafiados com ovoalbumina associada a alúmen e adjuvante completo de Freund, respectivamente. Vale salientar que, macrófagos apresentam receptores para lgG (CHUNG, 2015) e nesse sentido poderíamos inferir que macrófagos alveolares podem mediar o desencadeamento da migração pulmonar de neutrófilos. Estas comparações foram conduzidas em dados obtidos de animais não obesos, portanto, não podemos argumentar sobre o papel da obesidade no perfil da resposta imune. Todavia, vale lembrar que a obesidade 
interfere, pelo menos no tecido adiposo, com a população de macrófagos (RASMUSSEN et al., 2014). Além disso, nossos dados de citocinas indicaram aumento significativo de INFY, o qual exerce importante controle no balanço Th1/Th2 inibindo a reposta Th2 (CHUNG, 2015). Ainda, a obesidade per se eleva a concentração de INFY, assim podemos sugerir que em condições básicas a obesidade poderia ter um componente Th1 o qual na vigência da sensibilização poderia ser responsável pelo aumento da resposta inflamatória neutrofilica, refletindo na qualidade da atividade funcional de neutrófilos. É interessante notar que o perfil semelhante ao INFy, foi encontrado para a IL-17. Visto que IL-17 medeia ativação de neutrófilos e aumenta a geração de TNFa, e na obesidade há um "up regulation" de tal citocina (PABON et al., 2016). Então é razoável supor que, na asma neutrofílica, esses mecanismos podem ser subjacentes à ativação de neutrófilos na obesidade. Também merece destaque que a asma associada com obesidade, aumenta a IL-17, a qual desempenha um papel na gravidade da doença e na hiperresponsividade brônquica (NAKAHIR et al., 2014; SUZUKI et al., 2015).

Dados da literatura indicaram que aumento de IL-17 a qual prolonga 0 tempo de vida de neutrófilos e desvia a resposta imune, para um perfil Th1, sugerindo que os neutrófilos possam modular as respostas adaptativas, fornecendo um novo alvo terapêutico para asma de difícil controle (REYNOLD et al.; 2016). Além disso, existem estudos sugerindo que a IL-17 promove a inflamação neutrofílica, e desempenha um papel crucial na asma neutrofílica, uma vez que, demonstrou-se que em lavado broncoalveolar de pacientes com asma grave e em biópsia existe alto índice de interleucina IL-17 (WAN et al., 2016). Aumento de IL-17 também foi encontrado em animais obesos (DIXON et al., 2016).

É bem estabelecido que na asma se observa - se o desenvolvimento do quadro de remodelamento (FAHY, 2009). O remodelamento pode ser identificado através das alterações estruturais das vias aéreas, causando espessamento da membrana e aumento da massa do músculo liso das vias aéreas (NAVEED et al., 2016). Neste estudo nós observamos aumento na porcentagem de deposição de colágeno em animais sensibilizados e desafiados com OVA a qual foi exacerbada pela obesidade. Estes dados estão de acordo com aqueles achados por Dixon et al., (2016), indicando que a dieta rica em gordura associa - se à deposição de colágeno no pulmão, sugerindo ainda que a obesidade altere a estrutura das vias aéreas. 
Também avaliamos espessamento da camada muscular lisa e também da área de epitélio brônquico. Assim, detectamos aumento de espessura do epitélio e de músculo liso das vias aéreas nos animais do grupo OVA obeso os quais ficaram potencializados pela obesidade. Estudos realizados por Saraiva et al., (2011) também observaram aumento de espessura e aumento da porcentagem do músculo total das vias aéreas em modelo de asma eosinofílica, sugerindo que a obesidade induzida por dieta rica em gorduras está associada ao aumento de deposição de colágeno e aumento do espessamento das vias aéreas.

Tomados em conjunto, os dados apresentados neste estudo indicam que o modelo de asma neutrofílica está, sob o ponto de vista inflamatório, caracterizado e que o recrutamento de neutrófilos para o pulmão aparentemente independe da obesidade. Ainda, a obesidade poderia contribuir para uma exacerbação da inflamação pulmonar por induzir maior aporte de eosinófilos para o pulmão. Por fim, considerando as evidências clínicas envolvendo mulheres asmáticas, nossos estudos podem contribuir para a compreensão dos mecanismos que regulam a asma de difícil controle em mulheres obesas. 


\section{CONCLUSÃO}

1) O modelo experimental de obesidade induzido por dieta hiperlipídica foi caracterizado.

2) $O$ modelo de asma experimental neutrofílica foi padronizado visto o aumento de recrutamento de neutrófilos para o pulmão e a resistência da inflamação neutrofilica ao tratamento com corticoides.

3) A obesidade, aparentemente, não interferiu com a mecânica pulmonar nem com a magnitude do recrutamento de neutrófilos para o pulmão na vigência da asma neutrofílica.

4) É possível que, a obesidade altere o estado funcional de neutrófilos, mediando assim a piora da inflamação na asma neutrofílica.

5) A obesidade exacerbou o remodelamento das vias aéreas na asma neutrofílica, notadamente, na deposição de colágeno, espessamento da musculatura lisa e a porcentagem da área total.

6) A geração de citocinas na asma neutrofílica parece estar desviada para um perfil Th1, no qual a obesidade exerce efeito modulador.

Retomando a hipótese original deste estudo, nossos dados sugerem que a obesidade interfere negativamente no curso da asma neutrofílica basicamente por dois mecanismos, alterar o estado funcional de neutrófilos e exacerbar o remodelamento das vias aéreas. Por fim, considerando que mulheres obesas são mais susceptíveis ao desenvolvimento de asma neutrofílica, e que os nossos dados foram obtidos em camundongos fêmeas, os resultados deste estudo podem contribuir para a compreensão dos mecanismos orquestradores da asma neutrofílica em mulheres asmáticas obesas. 


\section{BIBLIOGRAFIA*}

ABALLAY, et al. Overweight and obesity: a review of their relationship to metabolic syndrome, cardiovascular disease, and cancer in South America. Nutr Rev. v. 71, n. 3, p.168-179, 2013.

AHIMA, R. S.; PRABAKARAN, D.; MANTZOROS, C.; QU, D.; LOWELL, B.; MARATOS-FLIER, E.; et al. Role of leptin in the neuroendocrine response to fasting. Nature. v. 382, p. 250-252, 1996.

ALAM, I. N.; LARDI, A. Does inflammation determine whether obesity is metabolically healthy or unhealthy? The aging perspective. Mediators Inflamm. v. 2012 Article ID 456456, 14 pages doi:10.1155/2012/456456.

ARAÚJO, E.P.; MORAES, J.C. Adipocitocinas e Controle da Ingestão Alimentar. CINTRA, D.E.; ROPELLE, E.R.; PAULI, J.R. Obesidade e Diabetes: Fisiopatologia e Sinalização Celular. Editora: Sarvier, 2011. Cap. 7 pág.126.

BALAGOPAL, P.; et al. Reduction of elevated serum retinol binding protein in obese children by lifestyle intervention: association with subclinical inflammation. J. Clin. Endocrinol. Metab. v. 92, n. 5, p. 1971-1974, 2007.

BANERJEE, R. R.; et al. Regulation of fasted blood glucose by resistin, . Science.v. 303, p.1195-1198, 2004.

BEUTHER DA, SUTHERLAND ER. Overweight, obesity, and incident asthma: a meta-analysis of prospective epidemiologic studies.Am J Respir Crit Care Med. v.175, n.7, p.661-666, 2007.

BERG, A. H.; SCHERER, P. E. Adipose tissue, inflammation, and cardiovascular disease. Circ Res. v. 96, p. 939-949, 2005*

\footnotetext{
* ASSOCIAÇÃO BRASILEIRA DE NORMAS TÉCNICAS. NBR 6023. Informação e documentação: referências: elaboração. Rio de Janeiro, 2002.
} 
BERSTEIN, I, L.; MALKIEL, S. A study of diverse humoral antibody systems following a single injection of Freund's incomplete adjuvante.J Allergy. v. 35, p. 390 - 8, 1964.

BHATT, A. N., LAZARUS, A.; Obesity-related asthma in adults. Clinical Focus: Allergies, autoimune disease and immunization Curr Drug Targets. ,2016.

BONDS, R. S.; MIDORO-HORIUTI, T. Estrogen effects in allergy and asthma. Curr Opin Allergy Clin Immunol. v. 13, n.1, p.92-99, 2013.

BOULET, L. P. Asthma and obesity. Clin Exp Allergy. V.43, n.1, p.8-21, 2013.

BROCH, M.; GÓMEZ, J. M.; AUGUET, M. T.; VILARRASA, N.; PASTOR, R.; ELIO, I.; OLONA, M.; GARCÍA-ESPAÑA, A.; RICHART, C. Association of retinol-binding protein-4 (RBP4) with lipid parameters in obese women. Obes Surg. v. 20, n. 9, p.1258-1264, 2010.

BRUMPTON, B.; LANGHAMMER, A.; ROMUNDSTAD, P.; CHEN, Y.; MAI, X. M. General and abdominal obesity and incident asthma in adults: the HUNT study. Eur Respir J. v. 41, n.2, p. 323-329, 2013.

BURCELIN, R.; CRIVELLI, A, C.; TIRELLI, A, R.; B. Heterogeneous metabolic adaptation of C57BL/6J mice to hight - fat diet. Am J Phisiol Endocrinol Metabol. v. 282, p. E834-842, 2002.

CALIXTO, C. M.; LINTOMEN, L.; SCHENKA, A.; SAAD, J. M.; ZANESCO, A.; ANTUNES, E. Obesity enhaces eosinophilic inflammation in a murine model of allergic asthma. Brit. J. of pharmacology. v. 159, p. 617-625, 2010.

CALIXTO, C. M.; et. al. Metformin attenuates the exacerbation of the allergic eosinophilic inflammation in hight fat-diet-induced obesity im mice. Plos one. v. 8, n. 10, p.1-13, 2013. 
CAMPOS, S.H.D.; LEOPOLDO AS.; et al. A obesidade preserva a função do miocárdio durante o bloqueio da via glicolítica. Arq Bras Cardiol., v. 103, n. 4, p. 330-337, 2014.

CAPELO, V. A.; FONSECA, M. V.; PEIXOtO, M. V. A.; CARVAlHO, G. G. L. Central obesity and other factors associated with uncontrolled astham in women. All. As. \& clinic. immunology., v. 11, n. 12, p. 01-08, 2015.

CARR, F. T; SERGEJS, B; SIMON, H. U; BOCHNER, S. B; ROSENWASSER, J. L. Eosinophilic bioactivities in severe asthma. WO. All. Orga. J. v.9, n.21, p.1-7, 2016

CASTRO-RODRIGUEZ, J. A; HOLBERG, C. J.; MORGAN, W. J. Increased incidence of asthma like symptoms in girls who become overweight or obese during the school years. Am J Respiratory Crit Care med. v. 163. P. 1344-349, 2001

CHAN, J. L.; HEIST, K.; DEPAOLI, A. M.; VELDHUIS, J. D.; MANTZOROS, C. S. The role of falling leptin levels in the neuroendocrine and metabolic adaptation to short-term starvation in healthy men. J Clin Invest. v. 111, p. 1409-1421, 2003.

CHANG, Y.; AL-ALWAN, L.; RISSE, P. A.; HALAYKO, A. J.; MARTIN, J. G.; BAGLOLE, C. J.; EIDELMAN, D. H.; HAMID, Q. Th17-associated cytokines promote human airway smooth muscle cell proliferation.FASEB J. v.26, n.12, p.5152-5160, 2012.

CHEN; Y.; CORNIER, Y.; DOSMAN, J. Atopy, obesity, and asthma in adults: the Humboldt study. J Agromedicine., v. 14, n. 2, p. 222-227, 2009.

CHESNE, J.; BRAZA, F.; MAHAY, G.; BROUARD, S.; ARONICA, M.; AGNAM, A. IL17 in severe asthma. Where do we stand? Am J Respir Crit Care Med. V. 190, n. 10, p. 1094-1101, 2014.

CHUNG, F.K. Asthma phenotypes: a necessity for improved therapeutic precision and new target therapies. J. Inter Medicine. p.01-13, 2015. 
CHUNG, K; WENZEL, S. E; BROZEK, J. International ERS/ATS guidelines on definition, evaluation and treatment of severe asthma. Eur Respir J. v.43, p. 343-76, 2014

CORREN, J. Asthma phenotypes and endotype: an evolving paradigm for classification. Discov Med., v. 15, n. 83, p. 243-249, 2013.

de Oliveira, A. P.; et al. Cellular recruitment and cytokine generation in a rat model of allergic lung inflammation are differentially modulated by progesterone and estradiol. Am J Physiol Cell Physiol. v.293, n.3, p.1120-1128, 2007.

de Oliveira, A. P.; et al. Female sex hormones mediate the allergic lung reaction by regulating the release of inflammatory mediators and the expression of lung $E$ selectin in rats. Respir Res. v.24, n.11, 2010.

DIXON, A.; POYNTER, E. M. A common pathaway to obesity and allergic asthma. Am J Respir Crit Care Med. v. 191, n. 7, p. 721-730, 2015.

DIXON, A.; MATTHEW, M.; POYNTER, E. Mechanisms of Asthma in obesity. Am J Respir Cell Mol Biol. v.54, n.5, p.601-608, 2016

ELGAZAR-CARMON, V. et al. Neutrophils transiently infiltrate intra-abdominal fat early in the course of high-fat feeding. J. Lipid Res. V. 49, p. 1894-1903, 2008.

ELMQUIST, J. K.; SCHERER, P. E. The cover. Neuroendocrine and endocrine pathways of obesity. JAMA. v. 308, p. 1070-1071, 2012.

ERZURUMM, S.C.; ZEIN, G.J. Asthma is Different in Women. J. Allergy Asthma. V. 15, n. 28., p. 01-10, 2015.

FARZAN. S. The asthma phenotype in the obese: distinct or otherwise? $\mathbf{J}$ Allergy (Cairo). v. 4, p. 249-260, 2013. 
FAHY, J, V.; Eosinophilic and neutrophilic inflammation in asthma: insights from clinical studies. Proc Am Thorac Soc. v. 3, p. 256-59, 2009. 1

FORD, E. S. The epidemiology of obesity and asthma. J. Allergy Clin Immunol. v.115. p.897-909, 2005.

GAO, P.; GIBBSON, P. G.; BAINNES, J. K.; YANG, I. A.; UPHAN, W. J.; REYNOLDS, N. P.; HODJE, S.; JAMES, L. A.; JENKINS, C.; PETERS, J. M.; ZHANG, J.; SIMPSON, J. L. Anti-inflammatory deficiencies in neutrophilic asthma: reduced galectin-3 and IL-1ß. Respiratory Research. v.16, n. 5, p.1-10, 2015

GEBER, S.; BRANDÃO, A. H.; SAMPAIO, M.Effects of estradiol and FSH on leptin levels in women with suppressed pituitary. Reprod Biol Endocrinol. v.15, p.10-45, 2012.

GRAÇA, J, M.; NOBRE, N.; MARQUES, Y .Obesidade e inflamação. Univ. Atlantica. 2010 .

GRAHAM, T. E.; YANG, Q.; BLÜHER. M.; HAMMARSTEDT, A.; CIARALDI, T. P.; HENRY, R. R.; WASON, C. J.; OBERBACH, A.; JANSSON, P. A.; SMITH, U.; KAHN, B. B. Retinol-binding protein 4 and insulin resistance in lean, obese, and diabetic subjects. N Engl J Med. v. 354, n.24, p. 2552,2563, 2006.

GREGOR, M. F.; HOTAMISLIGIL, G. S. Inflammatory mechanisms in obesity. Annu Rev Immunol. v. 29, p. 415-445, 2011.

GONZALES, D. C. Asma Grave. J. medicina (Buenos Aires). V. 76, p. 19-24, 2016.

HALDAR, P.; et al. Cluster analysis and clinical asthma phenotypes. Am J Respir Crit Care Med. v.178, n.3,p. 218-224, 2008.

HANCOX, J. R.; RASMUSSEN, F. Mechanisms of obesity in asthma. Curr Opin Allergy Clin Immunol.v.14, p.1, 2014. 
HANTOS, Z.; SUKI, B. Viscoelastic properties of the visceral pleura and its contribution to lung impedance..Respir Physiol. v.90, n.3, p.271-281, 1992.

JACOBSEN, A. E.; OCHKUR, I. S; DOYLE, E. W; LESUER, E. W; LE, W; PROTHERONE, A. C; COLBERT, D; ZELLNER R. K; SHEN, H. H; IRVIN, G. C; LEE, J. J; LEE, A. N. Lung pathologies in a chronic inflammation mouse model are independent of eosinophil degranulation. AJRCCM. v.10, n.3, p.1-43 2016.

JOHNSTON, S. L. Overview of virus-induced airway disease. Proc Am Thorac Soc. v.2, n.2, p.150-156, 2005.

JUEL, C.; T.; ULRIK, C. S. Obesity and asthma: impact on severity, asthma control, and response to therapy. Respir Care. v.58, n.5, p.867-873, 2013.

KANNEGANTI, T.D.; DIXIT, V.D. Immunological complications of obesity.Nat Immunol. v.13, n.8, p.707-712, 2012.

KAZUYUKI, N.; MATSUSHITA, SHO.; NAGATA, M. Neutrophilic inflamation in severe asthma. Int Arch Allergy Immunol., v. 158, n. 1, p. 96-102, 2012.

KIKUCHI, S.; KIKUCHI, I.; HAGIWARA, K.; KANAZAWA, M. Association between neutrophilic and eosinophilic inflammation in patients with severe persistentasthma. Int Arch Allergy Immunol., v. 1, p. 77-11, 2005.

KIKUCHI, S.; KIKUCHI, I.; TAKAKU, Y.; KOBAYASHI, T.; KANAZAWA, M.; NAGATA, M. Neutrophilic inflammation and CXC chemokines in patients with refractory asthma. Int Arch Allergy Immunol. v. 149, p. 87-93, 2009.

KIM, S.R; RHEE, Y.K. Overlap Between Asthma and COPD: Where the Two Diseases Converge. Allergy Asthma Immunol Res. v.2, n.4, p. 209-214, 2010.

KIM, Y.M.; KIM, Y. S.; JEON, S. G.; KIM, Y. K.. Immunopathogenesis of allergic asthma: more than the th2 hypothesis. Allergy Asthma Immunol Res. v. 5, n. 4, p. 189-196, 2013. 
KIM, H. S.; SUTHERLAND, R. E.; GELFAND, E. E. Is there a link between obesity and asthma ? Allergy asthma immunol Res. v. 6, n. 3, p. 189-195, 2014.

KIM, T. B; JANG, A. S; KWON, H.S. Identification of asthma clusters in two independent Korean adult asthma cohorts. Eur Respi. v. 41, p. 1308-1314, 2013.

KLOTING, N.; et al. Serum retinol-binding protein is more highly expressed in visceral than in subcutaneous adipose tissue and is a marker of intraabdominal fat mass. Cell. Metab.v. 69, p.79-87,2007.

KOPELMAN, G, P.; Obesity as medical proplem. Nature. V.404, p.635-43, 2000.

KUMAR, R. K.; HERBERT, C.; FOSTER, P. S. The "classical" ovalbumin challenge model of asthma in mice. Curr Drug Targets. v.9, n.6, p. 485-494, 2008.

LEE, G. H.; PROENCA, R.; MONTEZ, J. M.; CARROLL, K. M.; DARVISHZADEH, J. G.; LEE, J. I.; Abnormal splicing of the leptin receptor in diabetic mice. Nature. v. 379, p. 632-635, 1996.

LIGEIRO DE OLIVEIRA, A. P.; et al. Ovariectomized OVA-sensitized mice display increased frequency of CD4(+)Foxp3(+) T regulatory cells in the periphery. PLoS One. v.8, n.6, 2013.

LINTOMEN, L.; CALIXTO, M. C.; SCHENKA, A.; ANTUNES, E. Allergen-induced bone marrow eosinophilopoiesis and airways eosinophilic inflammation in leptindeficient ob/ob mice. Obesity (Silver Spring). v.20, n.10, p.1959-1965, 2012.

LUMENG, C. N.; SALTIEL, A. R. Inflammatory links between obesity and metabolic disease. J Clin Invest. v.121, n.6, p.2111-2117, 2011.

MALAFAIA, B. A; et al. Indução de Obesidade com sacarose em ratos. ABCD Arq Bras Cir Dig., n. 26, v. 1, p. 17-21, 2013. 
MANISCALCO, M; ZEDA, A; FARONE, S. Weight loss and asthma control in severly obese asthmatic female.Respir Med. v.102,n.1, p. 102-108, 2008

MC-CALLISTER, J. W; et al. Sex Differences in asthma symptom profiles and control in the American Lung Association Asthma Clinical. Respir. Med. v.107, n. 10, p. 1491-1500, 2013.

MOORE , E. C; MEYERS, D. A; WENZEL, S.E. Identification of asthma phenotypes using cluster analysis in the severe asthma research program. Am J Respir Crit Care Med. v. 181, n.4, p.315-323, 2010.

MOREL, L. J. F; AZEVEDO, C. B; CONTINI, T. H. S; CARMONA, F; TELES, M. A; RAMALHO, S. F; BERTONI, W. B; FRANÇA, C. C. S; BORGES, C. M; PEREIR, S. M. A. A standardized methanol extract of Eclipta prostrata (L.) L. (Asteraceae) reduces bronchial hyperresponsiveness and production of Th2 cytokines in a murine model of asthma. Journal of Ethnopharmacology. Doi: 10.1016/j.jep.2016.12.008, 2016

MONTEIRO, R.; AZEVEDO, I. I Chronic inflammation in obesity and the metabolic syndrome. Mediators Inflamm. doi: 10.1155/2010/289645, 2010.

NAKAGOME, K.; MATSUSHITA, S.; NAGATA, M.Neutrophilic inflammation in severe asthma. Int. Arch. of Allergy Immunology. s. 1, p.96-102, 2012.

NAKAHIRA, K.; CLONAN, S. M.; MIZUMURA, K.; CHOI, M. A; RYTER, S. W. Autophagy a crucial moderator of redox balance, inflammation and apoptosis in lung disease. Antioxid redox signal. v.20, p. 474, 494, 2014.

CLEMENTS, D. S; JACKSON J. D; NAVEED, S. N; PHILP, C; BILLINDTOL, K. C; SOOMRO, I; REYNOLDS, C; HARRISON, W. T; JOHNSTON, L. S; SHAW, E. D; JOHNSON, R. S. MMP-1 activation contributes to airway smooth muscle growth and asthma severity. AJRCCM. doi: 10.1164/rccm.201604-0822OC, 2016.

NERY, S. C.; PINHEIRO, L. I.; VASCNCELOS, A. A. D.; FRANÇA, P. S.; NASCIMENTO, E. Medidas murinométricas e eficiência alimentar em ratos 
provenientes de ninhadas reduzidas na lactação e submetidos ou não ao exercício de natação. Rev Bras Med Esporte. v. 17, n. 1, p. 49-55, 2011.

NEWCOMB, D. C.; PEEBLES, R. S. JR. Th17-mediated inflammation in asthma. Curr Opin Immunol. v. 25, n. 6, p. 755-760, 2013.

NIJHUIS, J. et al. Neutrophil activation in morbid obesity, chronic activation of acute inflammation. Obesity (Silver Spring). v. 17, p. 2014-2018, 2009.

NISHIMURA, S.; MANABE, I.; NAGASAKI, M.; et al. CD8+ effector T cells contribute to macrophage recruitment and adipose tissue inflammation in obesity. Nat Med. v. 15, n. 8, p. 914-920, 2009.

OERTELT-PRIGIONE, S.The influence of sex and gender on the immune response. Autoimmun Rev. v.11, n.6-7, p.79-85, 2012.

OUCHI, N.; KIHARA, S.; FUNAHASHI, T.; MATSUZAWA, Y.; WALSH, K. Obesity, adiponectin and vascular inflammatory disease. Curr Opin Lipidol. v. 14, p. 561566, 2003.

OUCHI, N.; PARKER, J.L.; LUGUS, J. J.; WALSH, K. Adipokines in inflammation and metabolic disease. Nat Rev Immunol.v. 11, p. 85-97, 2011.

OSBORN, O.; OLEFSKY, J. M. The cellular and signaling networks linking the immune system and metabolism in disease.Nat Med. n. 6, v.3, p. 363,374, 2012.

O'TOOLE, J.; MIKULIC, L.; KAMINSKY, A. D. Epidemiology and pulmonary physiology of severe asthma. Immunologgy clin. v.36, p.425-438, 2016.

PABON, M. A.; MA, K. C; CHOI, K. M. Autophagy and obesity-related lung disease. American Journal Respiratory Cell and Molecular Biology. v.54, n.5, p.636-646, 2016. 
PAIVINEN, K. M; KESKINEN, K. L; TIKKANEM, O. H. Swinmming and asthma differences between women and men. J Allergy. v. 7, n.3, p.467-97, 2013

PEELMAN, F.; COUTURIER, C.; DAM, J; ZABEAU, L.; TAVERNIER, J.; JOCKERS, R. Techniques: new pharmacological perspectives for the leptin receptor. Trends Pharmacol Sci. v. 27, p. 218-225, 2006.

PETERS, M. C; MC-GRATH, K. W; HAWKINS, G. A. Plasma interleukin-6 concentrations, metabolic dysfunction, and asthma severity: a croos - selectional analysys of two cohorts. Lancet Respir Med. v.16, p. 30048-30050, 2016.

PETERS, M. C; FAHY, J.Metabolic consequence of obesity as an 'outside in" mechanism of disease severity in asthma. Eur. Respir J. v.48, p. 291-293, 2016.

PELEGRIN, G, E, B.; SANTOS, A.; SULZBACHER, M, M.; BASSO, R, D, B.; DONATO, Y, H.; LUDWING, M, S.; HECK, T, G.. M. Parâmetros biométricos, glicêmico e lipíico de camundongos submetidos à ingestão de dieta hiperlipídica. VIII Seminário de Educação Física. 2013.

PRADO, C.M.; LEICK, E. A.; YANO, L.; LEME, S. A.; MARTINS, M. A.; TIBÉRIO, I. O. Effects of Nitric Oxide Synthases in Chronic Allergic Airway Inflammation and Remodeling.

American Journal of Respiratory Cell and Molecular Biology. v. 15, n. 5, Set/Out, 2009.

PRADO, W. L.; et al. Relationship between bone mineral density, leptin and insulin concentration in Brazilian obese adolescents. J Bone Miner Metab. v. 35, p. 458465, 2006.

QI, Y.; et al. Loss of resistin improves glucose homeostasis in leptin deficiency. Diabetes. v. 55, p.3083-3090, 2006. 
RASMUSSEN, F.; HANCOX, RJ. Mechanisms of obesity in asthma. Curr Opin Allergy Clin Immunol., v.14, n. 1, p. 35-43, 2014.

REYNOLD, A; PANETTIERI, Jr. Neutrophilic and pauci-immune phenotypes in severe asthma. Immunol Allergy Clin N Am. v. 36, p. 569-579, 2016

RIFFO-VASQUEZ, Y; LIGEIRO DE OLIVEIRA, A. P.; PAGE, C. P.; SPINA, D.; TAVARES-DE-LIMA. W. Role of sex hormones in allergic inflammation in mice.Clin Exp Allergy. v.37, n.3, p.459-470, 2007.

SANTAMARIA, F.; MONTELLA, S.; PIETROBELLI, A. Obesity and pulmonary disease: unanswered questions. Obes Rev. v.13, n.9, p. 822-833, 2012.

SARAIVA, A. S.; SILVA, L. A.; XISTO, G. D.; ABREU, C.S.; SILVA, J. D.; SILVA, L. P.; TEIXEIRA, P. F. T.; PARRA, R. E.; LAURA, N. A.; ANNONI, R.; MAUAD, T.; CAPELOZZI, L. V.; SILVA, R. M. P. MARTINS, A. M. ROCCO, M. R. P.Impact of obesity on airway and lung parenchyma remodeling in experimental chronic allergic asthma. Respiratory physiology \& neurobiology. v.177, p.141-148, 2011.

SCOOT, h. a; GIBSON, P. G; GARG, M. L. Dietary restriction and exercise improve airway inflammation and clinical outcomes in overweight and obese asthma : randomized trial. Clin Exp Allergy. v.43, p. 36-49, 2013.

SEIDELL, J. C.; DE GROOT, L. C.; VAN SONSBEEK, J. L.; DEURENBERG, P.; HAUTVAST, J. G. Associations of moderate and severe overweight with selfreported illness and medical care in Dutch adults. Am J Public Health. v.76, n.3, p.264-269,1986.

SENGER, N.; FIORINO, P. Estudo da morfometria de adipócitos em ratos recém desmamados submetidos a uma dieta hiperlipídica. VII Jornada de iniciação científica. 2011. 
SIDELEVA, O; SURATT, B. T; BLACK, K. E. Obesity and asthma: an inflammatory disease of adipose tissue not the airway. Am J. Respir Crit Care Med. v. 186, p. 598-605, 2012.

SCHIPPER, H. S.; PRAKKEN, B.; KALKHOVEN, E.; BOES, M. Adipose tissueresident immune cells: key players in immunometabolism. Trends Endocrinol Metab. v.23, n.8, p.407-415, 2012.

SHIM, E; et al. The association of lung fuction, bronchial hyperresponsiveness, and exhaled nitric oxide differs between atopic and non-atopic asthma in children. Allergy asthma immunol res. p. 1-7, 2015.

SHORE, S. A.; FREDBERG, J. J. Obesity, smooth muscle, and airway hyperresponsiveness. J Allergy Clin Immunol. v.115, n.5, p.925-927, 2005.

SHORE, S. A.; JOHNSTON, R. A. Obesity and asthma. Pharmacol Ther.v. 110, n.1, p. 83-102, 2006.

SHORE, S. A. Obesity and asthma: lessons from animal models. J Appl Physiol. v.102, n.2, p.516-528, 2007.

SHORE, S. A. Obesity and asthma: Possible mechanisms. J Allergy clin immunol. v.121 n.5, p.1087-93, 2008.

SHUTHERLAND, T. J; TAYLOR, D. R; SEARS, M. R. Association between wxhaled nitric oxide and systemic inflammatory makers. Ann Allergy Asthma Immunol. v.99, p.334-339, 2007.

SKOBELOFF, E. M.; SPIVEY, W. H.; SILVERMAN, R.; ESKIN, B. A.; HARCHELROAD, F; ALESSI, T. V. The effect of the menstrual cycle on asthma presentations in the emergency department. Arch Intern Med. v. 156, n.16, p.156$160,1996$. 
SOOD, A.; QUALLS, C.; SCHUYLER, M.; THYAGARAJAN, B.; STEFFES, M. W.; SMITH, L. J.; JACOBS, D. R. JR. Low serum adiponectin predicts future risk for asthma in women. Am J Respir Crit Care Med. v.186, n.1, p.41-47, 2012.

STEPPAN, C. M.; et al. The hormone resistin links obesity to diabetes Nature. v. 409, p. 307-312, 2001.

SUN, Q.; CORNELIS, M. C.; KRAFT, P. Q. I. L.; VAN, D. R. M.; GIRMAN, C. J.; et al. Genome-wide association study identifies polymorphisms in LEPR as determinants of plasma soluble leptin receptor levels. Hum Mol Genet. v. 19, p. $1846-1855$, 2010.

SUZUKI, Y.; SANKARANARAYANAM, I.; LAM, J.; KHOO, B.; SOROOSH, P.; BARBERS, R. G.; JAMES, O. J. H.; JUNG, J. U.; AKBARI, O. Lack autophagy induces steroid-resistant airway inflammation. J. Allergy Clin Immunol., NOV.2015

TAM, A,; MORRISH, D.; WADSWORTH, S.; DORSCHEID, D.; MAN, S. F.; SIN, D. $D$. The role of female hormones on lung function in chronic lung diseases.BMC Womens Health.v.3, p.11-24, 2011.

TANG, F.; TIAN, M, Y.; CHEN, Y.; HE, Q.; GAO, Z. The link between mold sensitivity and asthma severity in a cohort of northern Chinese patients. $\mathbf{J}$ Thorac Dis. v.4, p. $585-90,2015$.

TAKAGI, R.; KAWANO, M.; NAKAGOME, K.; HASHIMOTO, K.; HIGASHI, T.; OHBUCHI, K.; KANEKO, A.; MATSUSHITA, S. Wogonin attenuates ovalbumin antigen-induced neutrophilic airway inflammation by inhibiting th17 ifferentiation. Int $\mathbf{J}$ Inflam. v. $57,2014$.

TAKEDA, M.; TANABE, M.; et al. Gender Difference in Allergic Airway Remodeling and Immunoglobulin Production In Mouse Model of Asthma. Respirology.v.12, 2013. 
TAVARES de LIMA, W.; SIROIS, P.; S. Immune-Complex Alveolitis in the Rat: Evidence for Platelet Activating Factor and Leukotrienes as Mediators of the Vascular Lesions. Eurpean Journal Of Pharmacology, v. 213, p. 63-70, 1992.

TOWNSEND, E.A.; MILLER, V. M.; PRAKASH, Y.S. Sex differences and sex steroids in lung health and disease. Endocr. Rev. v. 33, n.1, p.1-47, 2012.

TLIBA, O.; PANETTIERI, R. A. JR;Noncontractile functions of airway smooth muscle cells in asthma. Annu Rev Physiol. v.71, p. 509-535, 2009.

THORNTON, J.; LEWIS, J.; LEBRUN, C. M.; LICSKAI, C. J. Clinical characteristics of women with menstrual-linked asthma. Respir Med. v.q06, n.9, p.1236-1243, 2012.

VIGITEL. Vigilância de fatores de risco e proteção para doenças crônicas por inquérito telefônico 2011, Brasília - DF, 2012.

VIGITEL. Vigilância de fatores de risco e proteção para doenças crônicas por inquérito telefônico 2012, Brasília - DF, 2013

VIGITEL. Vigilância de fatores de risco e proteção para doenças crônicas por inquérito telefônico 2013, Brasília - DF, 2014.

VON BEHREN, J.; LIPSETT, M.; HORN-ROSS, P. L.; et al. Obesity, waist size and prevalence of current asthma in the California Teachers Study cohort. Thorax. v.64, n. 10, p. 889-893, 2009.

ZÚÑIGA, L. A.; SHEN, W. J.; JOYCE-SHAIKH, B.; PYATNOVA, E. A.; RICHARDS, A. G.; THOM, C.; ANDRADE, S. M.; CUA, D. J.; KRAEMER, F. B.; BUTCHER, E. C.IL-17 regulates adipogenesis, glucose homeostasis, and obesity. J Immunol. v.186, n.02, p.1291, 2011.

YANG, Q.; et al. Serum retinol binding protein 4 contributes to insulin resistance in obesity and type 2 diabetes. Nature. v.436, p. 356-362, 2005. 
YANG, H.; YOUM, Y. H.; VANDANMAGSAR, B.; RAVUSSIN, A.; GIMBLE, J. M.; GREENWAY, F.; STEPHENS, J. M.; MYNATT, R. L.; DIXIT, V. D. Obesity increases the production of proinflammatory mediators from adipose tissue $T$ cells and compromises TCR repertoire diversity: implications for systemic inflammation and insulin resistance. J Immunol. v. 185, n. 3, p. 1836-1845, 2010.

YE, Z.; HUANG, Y.; LIU, D.; et al. Obesity induced by neonatal overfeeding worsens airway hyperresponsiveness and inflammation. PLoS One. v. 7, n.12, 2012.

WANG, C. Obesity, Inflammation, and Lung Injury (OILI): The Good. Mediators of Inflammation. 2014.

WANG, L., WANG, K., GAO, X., PAUL, K. T., CAI, J.; Sex difference in the association between obesity and asthma in U.S. adults: findings from a national study. Respiratory Medicine. v. 109, p.955-962, 2015.

WAN, X. C.; PRESCOTT, G.; WOODRUFF. Biomarkers in Severe Asthma. Immunl Allergy Clin N Am. v.36, p.547-557, 2016.

WEISBERG, S. P.; MCCANN, D.; DESAI, M.; ROSENBAUM, M.; LEIBEL, R. L.; FERRANTE, A. W. JR. Obesity is associated with macrophage accumulation in adipose tissue. J Clin Invest. v.112, n.12,p.1796,1808, 2003.

WENZEL, S. E; SCHWARTZ, L. B; LANGMACK, E. L; HALLIDAY, J. L; TRUDEAU, J. B; GIBBS, R. L; CHU, H.W. Evidence that severe asthma can be divided pathologically into two inflammatory subtypes with distinct physiologic and clinical characteristics. Am J. Respir Crit Care. v.160, p. 1001-1008, 2015.

WEISS, S. T. Obesity: Insight into the origins of asthma. Nat. Immunol. v.6, p.537539, 2005.

WINER, D.A.; WINER, S.; SHEN, L.; WADIA, P.P.; et al. B cells promote insulin resistance through modulation of $\mathrm{T}$ cells and production of pathogenic $\mathrm{IgG}$ antibodies. Nat Med. v.17, n.5, p.610-617, 2011. 
WHITE, S.A.P.; et al. Modelo de obesidade induzida por dieta hiperlipídica e associada à resistência à ação da insulina e intolerância à glicose. Arq Bras Endocrinol Metab., v. 57, n. 5, p. 339-345, 2013. 